RODRIGO BORSARI

\title{
Expressão gênica do leiomioma uterino em mulheres no período reprodutivo após tratamento com análogo agonista do GnRH
}

Tese apresentada à Faculdade de Medicina da Universidade de São Paulo para obtenção do título de Doutor em Ciências

Área de Concentração: Obstetrícia e Ginecologia Orientador: Dr. Nilo Bozzini

SÃo PAULO

2008 
Dados Internacionais de Catalogação na Publicação (CIP)

Preparada pela Biblioteca da

Faculdade de Medicina da Universidade de São Paulo

Creprodução autorizada pelo autor

\section{Borsari, Rodrigo}

Expressão gênica do leiomioma uterino em mulheres no período reprodutivo após tratamento com análogo agonista do GnRH / Rodrigo Borsari. -- São Paulo, 2008.

Tese(doutorado)--Faculdade de Medicina da Universidade de São Paulo. Departamento de Obstetrícia e Ginecologia.

Área de concentração: Obstetrícia e Ginecologia.

Orientador: Nilo Bozzini.

Descritores: 1.Leiomioma 2.Expressão gênica 3.Hormônio liberador de gonadotropina 4.Análise em microsséries 5 .Reação em cadeia da polimerase

USP/FM/SBD-304/08 


\section{DEDICO ESSE TRABALHO}

Aos meus pais, pela educação, amor e dedicação, a quem devo todo sucesso que obtiver na vida.

À minha esposa Cristina, pela compreensão, colaboração, atitude crítica e, sobretudo, pelo amor que norteia meus passos, ao qual procuro ser merecedor.

À Isabella e Giuliana, minhas amadas filhas, a quem devo transmitir meus valores. 


\section{AGRADECIMENTOS}

Às pacientes que contribuíram em toda minha formação acadêmica, desde a graduação, até a finalização desse trabalho.

Ao Prof. Dr. Edmund Chada Baracat, meu exemplo de liderança, pelas oportunidades oferecidas para o meu crescimento pessoal e profissional.

Ao Dr. Nilo Bozzini, meu professor na concepção mais pura da palavra, a quem devo minha formação e oportunidades, como médico ginecologista, mas, sobretudo, os ensinamentos paternais de atitudes perante a vida.

À Profa. Dra. Angela Maggio da Fonseca, por compartilhar sua experiência, me encorajar e orientar desde o início dessa jornada, possibilitando assim a realização desse trabalho.

Ao Prof. Dr. Maurício Simões Abrão, pelas orientações e ensinamentos, sobretudo no período em que fui preceptor.

Ao Prof. Dr. Nilson Roberto de Melo, pelos ensinamentos durante toda a residência médica e sua valiosa contribuição para finalização desse trabalho.

À Profa. Dra. Consuelo Rodrigues Junqueira, pelo encorajamento, impulso inicial e abertura do LIM 02 para concretização desse trabalho.

Ao Prof. Dr. Ismael Dale Cotrim Guerreiro da Silva, por compartilhar seu conhecimento na área de biologia molecular e abrir seu laboratório, nos auxiliando nas técnicas presentes nesse trabalho.

Ao Prof. Dr. José Maria Soares Júnior, pelo conhecimento e orientações dispensados desde o início desse trabalho.

À Sra. Gina Camilo, incansável profissional pela coleta, armazenamento e extração do material genético realizada com perfeição das amostras desse trabalho, além do ombro amigo e conselhos dados em momentos difíceis dessa trajetória. 
Aos colegas, Alexandre e Lucimara pela contribuição e auxílio ao trabalho desempenhado pelo Sra. Gina no LIM 02.

Aos amigos do Grupo de Leiomioma Uterino do HCFMUSP, Sandro Garcia Hilário, Marcos de Lorenzo Messina e Edison Luis Campos Júnior, pela colaboração na realização das cirurgias, além do apoio moral.

Aos amigos Cezar Matsuzaki, Décio Teshima e Carlos Tadashi, pelo apoio moral, entusiasmo pela conclusão desse trabalho e retaguarda profissional.

À Sra. Célia Conceição Morais, Srta. Mara Núbia, Sra. Sônia Regina Rodrigues, Sr. Moacir Lopes e Sr. Leslie Santos, por serem sempre prestativos e atenciosos.

À Sra. Claudia Vieira, pelo conhecimento inigualável do processo de pósgraduação na FMUSP, que desde a matrícula, teve papel fundamental para o sucesso desse trabalho.

À todos os colaboradores do ambulatório (em nome da Enfermeira Maria José) e da enfermaria (em nome da Enfermeira Regimara) da Ginecologia no HC-FMUSP, os quais trabalham com dedicação e respeito as mulheres.

À todos os colaboradores do Hospital Estadual Sapopemba, local onde desempenho meu mais importante e orgulhoso trabalho.

À Sra. Ruth e Sr. Celso pelo amizade e colaboração na minha educação.

À Sra. Shirley, minha sogra querida, pela palavras de apoio e compreensão. AO CNPq, pela bolsa oferecida. 
Esta tese está de acordo com as seguintes normas, em vigor no momento desta publicação:

Referências: adaptado de International Committee of Medical Journals Editors (Vancouver).

Universidade de São Paulo. Faculdade de Medicina. Serviço de Biblioteca e Documentação. Guia de apresentação de dissertações, teses e monografias. Elaborado por Anneliese Carneiro da Cunha, Maria Júlia de A. L. Freddi, Maria F. Crestana, Marinalva de Souza Aragão, Suely Campos Cardoso, Valéria Vilhena. 2a ed. São Paulo: Serviço de Biblioteca e Documentação; 2005.

Abreviaturas dos títulos dos periódicos de acordo com List of Journals Indexed in Index Medicus. 


\section{SUMÁRIO}

Lista de abreviaturas, símbolos e siglas

Lista de Tabelas

Lista de Figuras

Lista de Gráficos

Resumo

Summary

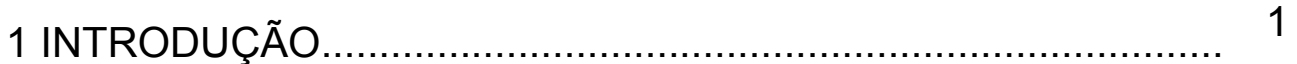

1.1 Etiopatogenia............................................................. 3

1.2 Análogo Agonista do Hormônio Liberador de Gonadotrofinas (GnRHa).

1.3 Aspectos citogenéticos do leiomioma uterino...................... 10

1.4 Biologia molecular do leiomioma uterino............................ 12

1.5 Análogo agonista de GnRH e biologia molecular.................. 19

1.6 Aspectos clínicos relevantes para a análise da expressão gênica do leiomioma uterino............................................... 21

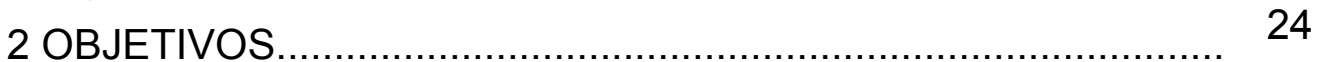

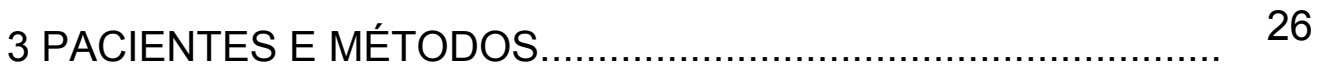

3.1 Pacientes.................................................................. 27

3.1.1 Critérios de inclusão............................................... 27

3.1.2 Critérios de exclusão................................................ 27

3.1.3 Fluxograma do estudo.............................................. 28

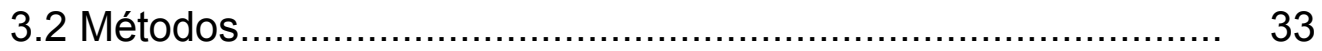

3.2.1 Técnica de "Microarray" ........................................... 33

3.2.1.1 Extração de RNA.............................................. 35

3.2.1.2 Síntese e marcação do RNA complementar.................... 35

3.2.1.3 Fragmentação do cRNA marcado com biotina................. 36

3.2.1.4 Hibridização do cRNA fragmentado.............................. 36

3.2.1.5 Lavagem, coloração e leitura do array........................... 37

3.2.2 PCR em tempo real.............................................. 37

3.3 Método estatístico................................................... 40 
4 RESULTADOS

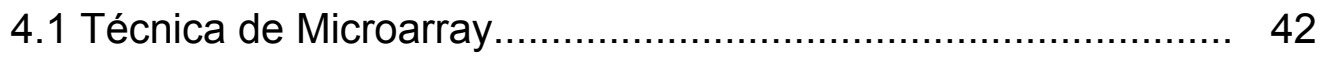

4.1.1 Normalização........................................................... 42

4.1.2 Genes diferentemente expressos...................................... 43

4.2 Confirmação por PCR em tempo real..................................... 49

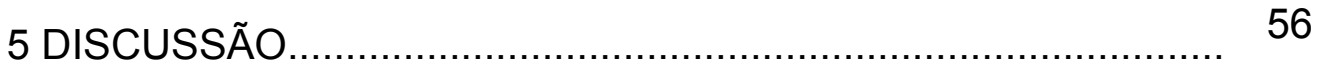

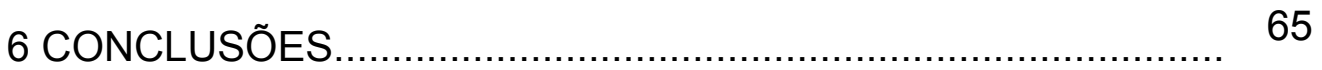

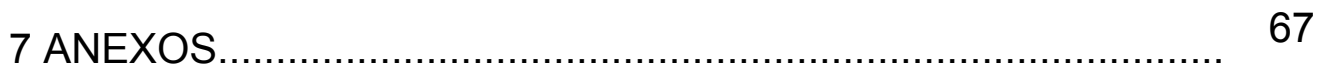

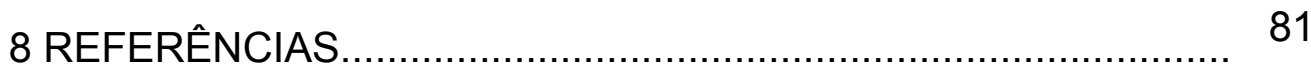




\section{LISTAS DE ABREVIATURAS}

\begin{tabular}{|c|c|}
\hline $\mathrm{mg}$ & miligrama \\
\hline${ }^{\circ} \mathrm{C}$ & Graus Celsius \\
\hline$\mu g$ & micrograma \\
\hline$\mu l$ & microlitros \\
\hline del & delação \\
\hline $\mathrm{dl}$ & Decilitro \\
\hline IMC & Índice de massa corpórea \\
\hline ins & inserção \\
\hline inv & inversão \\
\hline $\mathrm{Kg}$ & Kilograma \\
\hline LIM & Laboratório de Investigação Médica \\
\hline $\mathrm{m}$ & Metro \\
\hline $\mathrm{nm}$ & newton metro \\
\hline $\mathrm{p}$ & braço longo \\
\hline q & braço curto \\
\hline rpm & rotações por minuto \\
\hline $\mathrm{T}$ & Translocação \\
\hline
\end{tabular}




\section{LISTAS DE SIGLAS}

$\begin{array}{ll}\text { ADH } & \text { Alcohol dehydrogenase } \\ \text { ALDH } & \text { Aldehyde dehydrogenase } \\ \text { ANXA } & \text { Annexin A1 } \\ \text { APM } & \text { Adipocyte-specific secretory protein } \\ \text { ATF } & \text { Activating transcription factor } \\ \text { bFGF } & \text { Fator Básico de Crescimento de Fibroblastos } \\ \text { CCL } & \text { Chemokime ligared } \\ \text { CD24 } & \text { CD24 molecule } \\ \text { CD44 } & \text { CD44 molecule } \\ \text { CDKN1A } & \text { Cyclin-dependent kinase inhibitor 1A } \\ \text { CDNA } & \text { Àcido desoxirribonucleico codificado } \\ \text { COL4A2 } & \text { Collagen, type IV, alpha 1 } \\ \text { CPA } & \text { Carboxipeptidose } \\ \text { CRABP } & \text { Cellular retinoic acid binding protein } \\ \text { CREG } & \text { Cellular repressor of E1 A stimulated genes } \\ \text { CRMP } & \text { Collapsin response mediator protein } \\ \text { CRNA } & \text { Ácido ribonuclieco codificado } \\ \text { CTGF } & \text { Connective tissue growth factor } \\ \text { CYR } & \text { Indutor angiogênico rico em cisteína } \\ \text { DCX } & \text { Doublecortin } \\ \text { DEPC } & \text { Dietil-pirocarbonato } \\ \text { DLK } & \text { Mitogen-activated protein kinase kinase kinase 12 } \\ \text { DNA } & \text { Ácido desoxirribonucléico } \\ \text { DPT } & \text { Dermatoponina } \\ \text { DUSP } & \text { Dud especificity phosphatase } \\ \text { EGF } & \text { Epidermal growth factor } \\ \text { EGR } & \text { Resposta a crescimento inicial } \\ \text { EMP } & \text { Epithelial membrane protein } \\ \text { ER } & \text { Receptores de estrogênio } \\ \text { EST } & \text { Seqüências expressas conhecidas } \\ \text { ETRA } & \text { Endothelin receptor type A } \\ \text { FISH } & \text { Hibridização in situ por fluorescência } \\ \text { FOS } & \text { v-fos FBJ murine osteosarcoma viral oncogene homolog } \\ & \end{array}$




\begin{tabular}{|c|c|}
\hline FY & Fuzzy homolog \\
\hline FZD & Frizzled homolog \\
\hline GAPDH & Glyceraldehyde-3-phosphate dehydrogenase \\
\hline GnRH & Hormônio Liberador de Gonadotrofinas \\
\hline GnRHa & Análogo do Hormônio Liberador de Gonadotrofinas \\
\hline GRIA & Glutamate receptor, ionotropic, AMPA \\
\hline HMG & Grupo de proteína de alta mobilidade \\
\hline HMGN & Nucleossoma vinculado a grupo de alta mobilidade \\
\hline ID & Inhibitor of DNA binding \\
\hline IGF2 & Fator de crescimento similar a insulina 2 \\
\hline IGF2R & Receptores do IGF2 \\
\hline IGFBP6 & Proteína ligadora 6 do IGF \\
\hline IL11 & Interleucina 11 \\
\hline MAP3K5 & $\begin{array}{l}\text { Proteína } 3 \text { kinase } 5 \text { mitogênica ativada, indutora/mediadora da } \\
\text { apoptose }\end{array}$ \\
\hline MCL1 & Myeloid cell leukemia sequence 1 \\
\hline MEC & Matriz extracelular \\
\hline MEST & Mst and SOK1 - related kinase \\
\hline PARP & Poliadenosina difosfato ribose polimerose \\
\hline PCR & Reação em cadeia de polimerase em tempo real \\
\hline PDGFC & Fator de Crescimento- C Derivado das Plaquetas \\
\hline PTGDS & Prostaglandin D2 synthase 21kDa (brain) \\
\hline PTGER & Prostaglandin E receptor \\
\hline RNA & Ácido ribonucleico \\
\hline RNAm & Ácido ribonucleico mensageiro \\
\hline RT-PCR & Transcriptase reversa - reação em cadeia de polimerase \\
\hline SFRP & Secreted frizzled-related protein \\
\hline SULF & Sulfatase \\
\hline TGF- $\beta$ & Fator transformador de crescimento $\beta$ \\
\hline TGF $\beta R$ & Receptor de TGF $\beta$ \\
\hline TIMP & Metalopeptidose inibidor \\
\hline TNFSF & Tumor necrosis factor (ligand) superfamilu (TRAIL) \\
\hline TPS $\beta$ & Triptase $\beta$ \\
\hline TRAIL & Gene Ligante Indutor de Apoptose Relacionado ao TNF \\
\hline TYMS & Thymidylate synthetase \\
\hline VEGF & Vascular endothelial growth factor \\
\hline WIF & WNT fator inibidor \\
\hline
\end{tabular}




\section{LISTAS DE SímBolos}

$\begin{array}{ll}\Delta C T & \text { variação do ciclo limiar } \\ \beta & \text { beta } \\ \alpha & \text { alpha } \\ \mathrm{Ct} & \text { ciclo limiar } \\ \sim & \text { semelhante } \\ \mathrm{Ct}_{\text {GPDH }} & \text { ciclo limiar do glycerol-3-phosphate dehydrogenase } \\ \% & \text { porcentagem }\end{array}$




\section{LISTAS DE TABELAS}

Tabela 1 Alterações citogenéticas no leiomioma uterino.

Tabela 2 Genes relacionados à apoptose e proliferação celular, com expressão gênica alterada no leiomioma uterino por "microarray"

Tabela 3 Análise estatística comparativa entre os grupos A (tratado) e B (não tratado)

Tabela 4 Lista de genes super-expressos no Grupo A (Tratado) em relação ao Grupo B (Não-Tratado)

Tabela 5 Lista de genes sub-expressos no Grupo A (Tratado) em relação ao Grupo B (Não-Tratado).

Tabela 6 Valores da taxa de expressão diferencial obtidos por "microarray" para os 5 genes de interesse

Tabela 7 Resultado do PCR em tempo real dos 5 genes avaliados, usando as mesmas amostras do "microarray".

Tabela 8 Resultado do PCR em tempo real dos 5 genes estudados, usando as mesmas amostras do "microarray" adicionadas a outras 5 amostras de cada grupo. 


\section{LISTA DE FIGURAS}

Figura 1 Fluxograma proposto para confirmação de resultados do "microarray"................................................................. 11

Figura 2 Fluxograma do plano de atendimento ambulatorial.............. 23

Figura 3 Fluxograma: análise laboratorial........................................ 32

Figura 4 Verificação da integridade do RNA em gel de agarose 1\%... 35 


\section{LISTA DE GRÁFICOS}

Gráfico 1 Distribuições de intensidade das lâminas hibridizadas com amostras do Grupo A (Tratado).

Gráfico 2 Distribuições de intensidade das lâminas hibridizadas com amostras Grupo B (Não-Tratado).

Gráfico 3 Expressão comparativa, por "microarray", do gene

CYR61, nos dois grupos estudados.

Gráfico 4 Expressão comparativa, por "microarray", do gene HMGN1, nos dois grupos estudados.

Gráfico 5 Expressão comparativa, por "microarray", do gene EGR 1 , nos dois grupos estudados.

Gráfico 6 Expressão comparativa, por "microarray", do gene

SULF2, nos dois grupos estudados.

Gráfico 7 Expressão comparativa, por "microarray", do gene WIF 1 , nos dois grupos estudados.

Gráfico 8 Expressão média, por PCR em tempo real, do gene WIFI nos grupos com e sem análogo.

Gráfico 9 Expressão média, por PCR em tempo real, do gene EGR 1 nos grupos com e sem análogo.

Gráfico 10 Expressão média, por PCR em tempo real, do gene SULF 2 nos grupos com e sem análogo.

Gráfico 11 Expressão média, por PCR em tempo real, do gene HMGN 1 nos grupos com e sem análogo.

Gráfico 12 Expressão média, por PCR em tempo real, do gene CYR 61 nos grupos com e sem análogo. 


\section{RESUMO}

Borsari R. Expressão gênica do leiomioma uterino em mulheres no período reprodutivo após tratamento com análogo agonista do GnRH [Tese]. São Paulo: Faculdade de Medicina, Universidade de São Paulo; 2008.

OBJETIVO: Identificar os genes diferencialmente expressos entre os leiomiomas uterinos de pacientes em idade reprodutiva, tratadas ou não com análogo do $\mathrm{GnRH}$ e confirmar os resultados obtidos para genes selecionados por técnica de PCR em tempo real. PACIENTES E MÉTODOS: Foi colhida amostra do maior nódulo de leiomioma uterino de 89 pacientes negras, idade entre 20 e 45 anos, com indicação cirúrgica de miomectomia. Dessas, 38 receberam análogo do $\mathrm{GnRH}$ previamente a cirurgia (Grupo A) e 51 foram submetidas a cirurgia sem tratamento prévio (Grupo B). Dentro de cada grupo foram selecionadas 10 pacientes nulíparas, com maior nódulo acima de $3,0 \mathrm{~cm}$, volume uterino acima de $300 \mathrm{cc}$. e amostras colhidas na fase lútea no Grupo B. INTERVENÇÃO: 5 amostras de cada grupo foram analisadas por técnica de microarray e posteriormente genes diferencialmente expressos foram analisados por técnica de PCR em tempo real em 10 pacientes de cada grupo. RESULTADOS: Do total de 47.000 seqüências da plataforma Affymetrix, representando em torno de 38.500 genes humanos já caracterizados, resultou na expressão diferencial de 174 genes, sendo 70 super-expressos (33 com função conhecida) e 104 subexpressos (65 com função conhecida) em amostras do Grupo A (Tratado) comparativamente ao Grupo B (Não-Tratado). Os genes super-expressos CYR 61, EGR 1 e SULF 2 e o sub-expresso, WIF 1 foram confirmados por PCR em tempo real, enquanto o gene HMGN1 não teve confirmação da sua super-expressão após PCR em tempo real. CONCLUSÕES: Há alteração da expressão gênica de leiomioma uterino de mulheres submetidas a tratamento com análogo de $\mathrm{GnRH}$ em relação às não tratadas. O número de genes sub-expressos é o dobro dos super-expressos e $80 \%$ das alterações detectadas pela técnica de microarray foram confirmadas por PCR em tempo real.

Descritores: Leiomioma, Expressão gênica, Hormônio liberador de gonadotropina, Análise em microsséries, Reação em cadeia de polimerase. 


\section{SUMMARY}

Borsari R. Genic expression of uterine leiomyoma in women during the reproductive age after treatment with agonist GnRH analogue [thesis]. São Paulo: "Faculdade de Medicina, Universidade de São Paulo"; 2008.

OBJECTIVE: To identify the genes differentially expressed between the uterine leiomyomas of patients in reproductive age, treat or not treated with $\mathrm{GnRH}$ analogue and confirm the results for genes selected by real time PCR. METHODS: It was harvested sample of the largest lump of uterine leiomyoma of 89 black patients, aged between 20 and 45 years, with details of surgical miomectomia. Of these, 38 patients received $\mathrm{GnRH}$ analogue prior to surgery (Group A) and 51 were undergoing surgery without prior treatment (Group B). Within each group were selected 10 patients nulliparous, with higher nodule over $3.0 \mathrm{~cm}$, uterine volume over $300 \mathrm{cc}$. and samples taken during lutea in Group B. INTERVENTION: 5 samples from each group were analyzed by microarray, and then differentially expressed genes were analyzed by real time PCR on 10 patients in each group. RESULTS: Of the 47,000 sequences of the platform used, representing around 38,500 human genes already characterized, resulted in differential expression of 174 genes, with 70 genes up regulated (33 genes with known function) and 104 down regulated (65 genes with known function) in samples of Group A (Treaty) compared to Group B (Non-Treaty). The up regulated genes CYR 61, EGR 1 and SULF 2 and down regulated, WIF 1 were confirmed by real time PCR, while the gene HMGN1 had no confirmation of expression after real-time PCR. CONCLUSIONS: There is change in the gene expression of uterine leiomyoma of women undergoing treatment with $\mathrm{GnRH}$ analogue regarding women not treated. The number of genes underexpressed genes is double the down regulated and $80 \%$ of the changes detected by microarray were confirmed by real time PCR.

Descriptors: Leiomyoma, Genic expression, Gonadotropin release hormone, Microarray, Polymerase Chain Reaction 
1 INTRODUÇÃO 
O leiomioma uterino é o tumor pélvico sólido mais freqüente nas mulheres em idade reprodutiva. Apresenta incidência de $77 \%$, considerandose nódulos de até $2 \mathrm{~mm}$ em peças de histerectomia. Em achados de ultrasom, varia de $30 \%$, em torno de 35 anos de idade, a $80 \%$, ao redor dos 50 anos. Por ser, na maioria dos casos, assintomático, estima-se que a sua prevalência possa ser ainda maior (Parker, 2007).

Em 2003, foram realizadas, nos EUA, 602.457 histerectomias, que corresponde a uma taxa de 5,38 por 1.000 mulheres/ano. Dessas, 538.722 foram feitas por doença benigna (4,81 por 1.000 mulheres/ano), sendo o leiomioma uterino a indicação de um terço dos casos de histerectomias (Wu et al., 2007).

Entre os fatores de risco, realçam a raça negra (mulheres afroamericanas apresentam uma razão de chances de 9,4 em relação às brancas); menarca (menarca antes dos 11 anos tem razão de chances de 2,4 em relação a menarca após os 13 anos); história familiar (antecedente de leiomioma em parentes de primeiro grau aumenta o risco da doença em 4 a 5 vezes) e índice de massa corpórea - IMC (mulheres obesas com IMC $>30 \mathrm{Kg} / \mathrm{m}^{2}$ possuem razão de chances de 2,3 em relação àquelas com $\left.\mathrm{IMC}<25 \mathrm{Kg} / \mathrm{m}^{2}\right)$.

Dentre os fatores considerados protetores, citam-se o uso habitual de anticoncepcionais orais (razão de chances de 0,2 ); paridade (multíparas apresentam risco menor em relação às nuligestas); idade da primeira gestação (entre 25 e 29 anos de idade provê proteção, quando comparada a gestação abaixo dos 25 anos e acima dos 30 anos) e tabagismo acima de 
19 anos (razão de chances de 0,6) (Schwartz, 2001; Parker, 2007).

Quanto ao quadro clínico, sangramento uterino excessivo ou dor pélvica ocorrem de $20 \%$ e $50 \%$ dos casos. Cerca de $30 \%$ apresentam-se com sangramento uterino excessivo, sendo a menorragia o sintoma mais freqüente. $O$ aumento do volume uterino, com freqüência, promove compressão de órgãos adjacentes, como reto e bexiga, determinando alterações do hábito intestinal ou urinário (Parker, 2007).

O diagnóstico do tumor é feito, em geral, pela associação de dados da anamnese e dos exames ginecológico e de imagem. Deve-se destacar, no diagnóstico diferencial, endometriose, adenomiose, carcinoma de endométrio, sarcoma uterino, entre outros. Essas afecções podem ainda coexistir com o leiomioma uterino, especialmente a adenomiose e a endometriose (Parker, 2007).

Apesar da alta prevalência dessa afecção, sua etiopatogenia ainda não é completamente conhecida. A falta de um modelo de desenvolvimento desse tumor em animais tem limitado as pesquisas. Estudos recentes demonstram que o desenvolvimento e o crescimento dos leiomiomas resultam de complexa interação entre hormônios esteróides, fatores de crescimento, citocinas e mutações somáticas (Sozen; Araci, 2002).

\subsection{Etiopatogenia}

O estudo da etiopatogenia de tumores pressupõe a ação de fatores 
iniciadores e promotores de seu desenvolvimento. No caso do leiomioma uterino, os primeiros ainda são desconhecidos. Alguns trabalhos sugerem que a elevação dos níveis de estrogênio e de progesterona incrementaria a taxa de mitose, a qual poderia contribuir com o aumento de mutações somáticas (Rein, 2000).

A patogênese do leiomioma uterino tem sido relacionada, há muitos anos, com a ação do estrogênio e da progesterona. A presença de receptores para esses hormônios no tecido miomatoso tem sido estudada há décadas. Há evidências de maiores concentrações de receptores de estrogênio e de progesterona no tumor, em relação ao miométrio adjacente (Wilson et al., 1980). Fatores epidemiológicos, como a maior incidência dessa neoplasia em mulheres na idade reprodutiva, naquelas com menarca antes dos 11 anos, nuligestas e, principalmente, sua regressão após a menopausa, são achados que reforçam a hipótese de influência dos hormônios ovarianos na sua etiopatogenia. Mais recentemente, o efeito terapêutico promovido pelos análogos do hormônio liberador de gonadotrofinas $(\mathrm{GnRHa})$, reduzindo o seu volume, reforça a ação dos esteróides ovarianos no desenvolvimento e crescimento desse tumor. Bastante utilizado na prática clínica, o GnRHa cria um ambiente hipoestrogênico, afetando tanto o miométrio, quanto o leiomioma. No entanto, isoladamente, esses achados clínicos não esclarecem, de modo completo, a etiopatogenia dessa afecção, uma vez que estudos "in vitro" não demonstraram a ação direta dos hormônios ovarianos como promotores de crescimento tumoral (Porter et al., 1995). 
Outros pesquisadores defendem a teoria de que a patogênese do leiomioma seria uma resposta a um dano tecidual, à semelhança do que ocorre com a formação de quelóides. A lesão tecidual seria causada pelo aumento de substâncias vasoconstritoras (prostaglandinas e vasopressinas) no miométrio durante a menstruação, como ocorre na dismenorréria (Stewart; Nowack, 1998). Como reação a essa lesão, haveria aumento da produção de fator básico de crescimento de fibroblastos (bFGF), com conseqüente acúmulo de matriz extracelular (MEC) (Flake et al., 2003).

Concomitantemente, Sozen e Araci (2002), em trabalho de revisão, ressaltaram a importância de fatores de crescimento e de citocinas como agentes intermediários necessários para a ação dos esteróides sexuais. Para esses autores, alguns fatores de crescimento, como o transformante $\beta$ (TGF-ß), atuariam tanto na proliferação celular, como no acúmulo de MEC. Assinalaram, ainda, que o TGF- $ß$ sofreria ação do GnRHa. Desse modo, a atuação não se daria apenas pelo hipoestrogenismo, mas ter-se-ia que considerar também um efeito direto na regulação celular do leiomioma e do miométrio.

Apesar do conhecimento sobre a interação dos hormônios esteróides com os fatores de crescimento e as citocinas, a falta de uma base molecular para explicar esses achados direcionou as pesquisas para o estudo de fatores genéticos. Tal fato baseou-se nos seguintes achados clínicos:

a) A raça negra tem maior risco do que as outras para desenvolver o leiomioma. Esses surgem mais precocemente, tendem a ser maiores, mais numerosos e causam, em geral, sintomas mais 
intensos (Day Baird et al., 2003);

b) Gêmeos univitelínicos têm correlação duas vezes maior do que os dizigóticos para o desenvolvimento desses tumores (Gross; Morton, 2001);

c) Os leiomiomas são 4 a 5 vezes mais freqüentes em parentes de primeiro grau de mulheres com esses tumores, em comparação à população geral (Schwartz et al., 2000);

d) A síndrome de Reed, rara alteração genética, caracteriza-se pelo surgimento de múltiplos leiomiomas na pele e no útero (Reed et al., 1973);

e) Tanto os leiomiomas uterinos como os cutâneos, como o carcinoma de células papilares renal, estão ligados à mutação no gene da fumurato hidratase (Tomlinson et al., 2002);

f) Em modelo animal com ratos Eker, o desenvolvimento de leiomiomas uterinos está, com freqüência, associado à mutação no gene supressor da esclerose tuberosa 2 (Walker et al., 2003).

\subsection{Análogo agonista do hormônio liberador de gonadotrofinas (GnRHa)}

Diversos autores demonstraram que a administração de GnRHa reduz significativamente o tamanho dos leiomiomas uterinos. Essas substâncias 
são sintetizadas a partir da estrutura química do hormônio endógeno. Sua potência é determinada pela presença de modificação na seqüência de aminoácidos. A substituição da posição 6 ou 10 resulta em análogos com atividades agonistas, enquanto a das posições 2 e 3 em substâncias antagonistas. Os análogos agonistas possuem uma ação inicial estimuladora (efeito flare-up), seguida de inibição do eixo hipotálamo-hipofisário, o que resulta em decréscimo significativo da síntese de esteróides ovarianos. Os antagonistas, por sua vez, têm ação inibitória imediata (Bozzini et al., 2004).

O GnRHa acha-se indicado no tratamento de leiomioma uterino como terapia neoadjuvante nos casos com tumor volumoso e/ou anemia associada, objetivando reduzir o volume uterino. Determina, também, menor sangramento intra-operatório, incisões mais estéticas e, até mesmo, possibilita a indicação da via endoscópica ou vaginal, tornando o procedimento cirúrgico menos agressivo (Bozzini et al., 1994; Lethaby et al., 2001).

Em pacientes com ciclos hipermenorrágicos que se apresentam anêmicas, o GnRHa, por induzir a ausência de menstruação, é eficaz na melhora das condições clínicas pré-operatórias, reduzindo a necessidade de transfusão sangüínea no período peri-operatório (Bozzini et al., 1994; Lethaby et al., 2001).

Pacientes com essa neoplasia, tratadas com GnRHa, apresentam variação percentual na redução volumétrica do conjunto útero-leiomioma, demonstrando, com isso, que o fármaco atua de maneira individualizada. Bozzini et al. (2003) observaram redução variável (casos acima de 36\%, 
outros abaixo desse valor) do conjunto útero-leiomioma em mulheres nuligestas medicadas com GnRHa (Gosserrelina).

O GnRHa induz a depleção de estrogênio e conseqüente redução do volume do tumor. Bozzini et al. (2003), assim como Cirkel et al. (1994), demonstraram haver correlação significante e negativa entre a quantidade de células positivas para receptor de estrogênio e a intensidade de redução do volume do leiomioma, em pacientes tratadas com GnRHa.

Sozen e Araci (2002) sugeriram que a variação de volume do leiomioma em pacientes tratadas com GnRHa estaria relacionada à redução da MEC. Já Rein et al. (1993) aventaram a possibilidade de haver diminuição do conteúdo líquido da matriz e do número de células. Kalir et al. (1998) sugeriram que a polimerização das fibras colágenas, após o tratamento com GnRHa, poderia causar aumento da concentração de colágeno. Bozzini et al. (2003) também registraram incremento de colágeno nos leiomiomas que tiveram maior redução de volume, após tratamento com GnRHa.

Essas variações individuais da resposta do leiomioma, em relação à terapia com GnRHa, estaria relacionada, em parte, ao seu crescimento autônomo. Este, por sua vez, estaria relacionado com mutações somáticas que induziriam a alterações cromossômicas. O significado biológico destas anormalidades cromossômicas, envolvendo o crescimento ou a resposta aos fármacos, ainda não foi definitivamente demonstrado.

Estudos relatam que a alteração da celularidade, causada pelo GnRHa no leiomioma, seria induzida pela atrofia celular e/ou redução do 
número de células (lesão celular, degeneração e necrose), provavelmente por apoptose (Ito et al., 2001). Sabe-se que o tratamento com GnRHa aumenta a resistência vascular, reduzindo o fluxo sangüíneo uterino (Spong et al., 1995). Esta isquemia relativa causaria estresse oxidativo, o qual danificaria o ácido desoxirribonucléico (DNA), sendo, então, ativados os mecanismos de reparo do DNA e de proteção celular (Nagayama et al., 2000). Dessa forma, o GnRHa causaria a redução do leiomioma uterino ao induzir também alterações citogenéticas.

A evolução das pesquisas sobre os mecanismos de ação do GnRHa adicionaram à teoria inicial de regressão tumoral, atribuída à queda dos níveis de hormônios esteróides circulantes, tanto uma ação autócrina quanto parácrina dessa substância em tecidos extra-pituitários. Esta constatação é atribuída à presença de receptores de alta afinidade de $\mathrm{GnRHa}$, além da expressão do próprio $\mathrm{GnRH}$ e de seu receptor no tecido tumoral (Chen et al., 2005).

Estudo em células cultivadas de leiomioma uterino demonstrou a ação direta do GnRHa na supressão da proliferação celular e da apoptose (Wang et al., 2002). Alguns autores relataram, ainda, haver uma ação distinta do GnRHa, com regressão maior do miométrio em relação ao leiomioma uterino (Carr et al., 1993). Essa observação clínica, atualmente, tem sido respaldada por estudos recentes em biologia molecular (Chegini et al., 2003). 


\subsection{Aspectos citogenéticos do leiomioma uterino}

A análise citogenética de material obtido de cirurgias uterinas, envolvendo o leiomioma, demonstra, de forma inequívoca, a participação de alterações cromossômicas, numéricas ou estruturais, na gênese do tumor. Anomalias cromossômicas foram detectadas em $40 \%$ dos tecidos analisados e incluem translocações, trissomias, rearranjos e deleções (Moraes; Ribeiro, 2005).

Estudos citogenéticos revelaram que os leiomiomas mais volumosos apresentam maior probabilidade de ter cariótipo anormal, em comparação aos menores (Kataoka et al., 2003). Quando ocorrem deleções, a extensão da perda também contribui para o seu crescimento (Sell et al., 2005). Observou-se, ainda, que frente a alterações envolvendo o cromossomo 12 , os tumores tendem a ser maiores em relação àqueles com alteração do cromossomo 7 (Rein et al., 1993). Algumas cromossomopatias específicas, como deleção do braço curto do cromossomo 7 [del(7q)], translocação do 12 no 14 [t(12;14)], trissomia do 12, e rearranjo do braço curto do 6 , são detectadas em mais de $30 \%$ das anomalias cromossômicas observadas em leiomiomas, sugerindo haver alguns genes candidatos (Tabela 1) (Nilbert et al., 1990; Ligon; Morton, 2000; Takahashi et al., 2001). Das cromossomopatias encontradas, $20 \%$ delas corresponderiam a translocação t(12;14)(q14-q15;q23-q24), sendo que a presença de uma cópia extra do segmento q12-q15, e/ou a deleção do segmento q14-q24, poderia ser um fator preponderante para a intrusão e proliferação do leiomioma dentro dos 
vasos sangüíneos, caracterizando a rara leiomiomatose intravascular (Dal Cin et al., 2003). Outras translocações do cromossomo 12 podem envolver os autossomos de números 2,4 e 22 , e o cromossomo sexual $X$, sendo que a região do cromossomo 12 envolvida na translocação é consistentemente a q14-q15. De acordo com estudos de hibridização in situ por fluorescência (FISH), essa região translocada do cromossomo 12 estaria envolvida com a quantificação das proteínas HMGIC (grupo de proteínas de alta mobilidade). Estas proteínas estariam envolvidas na fisiopatologia dos leiomiomas uterinos, pois, sua expressão é elevada nesses tumores, não sendo observada no tecido miometrial normal (Gross; Morton, 2001).

Tabela 1 - Alterações citogenéticas no leiomioma uterino

\begin{tabular}{lcll}
\hline \multicolumn{1}{c}{$\begin{array}{c}\text { Aberrações } \\
\text { cromossômicas }\end{array}$} & $\begin{array}{c}\text { Freqüência } \\
\text { (\%) }\end{array}$ & Referências & Gene candidato \\
\hline $\mathrm{t}(12 ; 14)(q 14-q 15 ; \mathrm{q} 23-q 24)$ & 20 & Ligon; Morton, 2000 & TGFß3, HMGA2 \\
$\operatorname{del}(7)(q 22-q 32)$ & 17 & Ligon; Morton, 2000 & Inúmeros \\
Trissomia do 12 & 12 & Nilbert et al., 1990 & Inúmeros \\
$6 \mathrm{p} 21$ (del, inv, t, ins) & $<5$ & Ligon; Morton, 2000 & HMGA1 \\
\hline
\end{tabular}

Fonte: Modificado de Flake et al., 2003.

Outra anomalia cromossômica freqüente é o rearranjo do braço curto do cromossomo 6. Essas alterações podem incluir a translocação desse segmento para os cromossomos 1, 2, 4, 10 e 14, assim como as inversões (Moraes; Ribeiro, 2005). 
Como se depreende desses dados, o estudo citogenético do leiomioma é rico e detalhado, colaborando para o mapeamento das alterações cromossômicas e sua relação com os achados clínicos. No entanto, esse mapeamento não é suficiente para afirmar a participação de genes específicos, e tampouco a alteração da produção protéica nos tecidos afetados. Para o estudo da expressão gênica e da transcrição protéica, deve-se analisar o tecido-alvo com foco na estrutura e função do gene e seus produtos, por meio de técnica de biologia molecular.

\subsection{Biologia molecular do leiomioma uterino}

O desenvolvimento de técnicas de biologia molecular proporciona, atualmente, o estudo de milhares de genes simultaneamente, com a finalidade de identificar aqueles que estariam envolvidos na patogênese dos leiomiomas. Com o emprego da técnica de "microarray" pode-se identificar o ácido ribonucléico mensageiro (RNAm) de milhares de genes expressos nos tecidos leiomiomatosos.

A partir da identificação, por "microarray", dos genes mais freqüentemente alterados no tecido leiomiomatoso, cada um deles pode ser estudado, de maneira específica, por outras técnicas de biologia molecular (PCR em tempo real - reação em cadeia da polimerase em tempo real, RT PCR - transcripsase reversa / reação em cadeia da polimerase, Westhern Blot e imunoistoquímica). Dessa forma, estudos apontam para genes 
associados à apoptose e à proliferação celular, sendo esses preferencialmente estudados em afecções tumorais, como o leiomioma. Entre eles, assinalam-se os genes TRAIL (ligante indutor de apoptose relacionado ao fator de necrose tumoral); MAP3K5 (proteína kinase 5 mitogênica ativada, indutora/mediadora da apoptose); TGF-ß1 e PDGFC (Fator de Crescimento - C Derivado das Plaquetas) (Hoffman et al., 2004).

Outros genes podem estar relacionados ao crescimento e à proliferação das células do leiomioma. O principal gene envolvido nesse sentido, observado pela análise de "microarray", é o fator de crescimento similar à insulina 2 (IGF2). De maneira correlata, o IGF2 está envolvido na proliferação, diferenciação e transformação de uma grande variedade de tipos celulares, sendo regulado negativamente por uma proteína de ligação 6 do fator de crescimento similar à insulina (IGFBP6). Baixos níveis de IGFBP6 levariam ao aumento da bioatividade do IGF2 e, conseqüentemente, ao crescimento do leiomioma uterino. Já mutações, perda dos receptores do IGF2 (IGF2R), ou redução na expressão das IGFBPs com alta afinidade pelo IGF2, levariam ao incremento da expressão desse gene (Arslan et al., 2005).

Entre os genes que se encontram regulados negativamente nos leiomiomas, encontram-se o da triptase $ß 2$ (TPSB2) e o da carboxipeptase A3 (CPA3), enzimas produzidas pelos mastócitos. A diminuição da expressão dessas enzimas estaria relacionada à queda do estado de diferenciação, e pode indicar redução do número ou da função dos mastócitos no leiomioma uterino (Arslan et al., 2005). 
Outros genes ainda podem estar relacionados com a MEC, a qual desempenha papel importante na fisiopatologia do leiomioma uterino. A superprodução de proteínas da MEC contribuiria para o aumento do volume do leiomioma (Sozen; Araci, 2002). A redução na expressão de dermatopontina (DPT) e o aumento do gene TGF-ß3, por exemplo, foi proposta como um fator molecular de ligação entre os leiomiomas e a formação de quelóides (Catherino et al., 2004). Além disso, o gene de ligação do TGF ß3, que o regula negativamente, está localizado muito perto da região de quebra 14q23-24, relacionada com a translocação mais comum observada nos leiomiomas, reforçando o eventual papel do gene TGF-ß3 no desenvolvimento desses tumores (Moraes; Ribeiro, 2005).

Tsibris et al. (2002) estudaram amostras de leiomioma e de miométrio normal em nove pacientes (5 Afro-Americanas, 2 Caucasianas, 1 Hispânica, 1 de outra etnia) nas fases secretória e proliferativa do ciclo menstrual, utilizando o HU Gene FL6800 Gene Chip (6.800 genes) e Affymetrix U95A Gene Chip (12.000 genes). A análise dos dados resultou na observação de 67 super-expressos e de 78 sub-expressos no tumor em relação ao miométrio.

Weston et al. (2003), utilizando uma plataforma própria para “microarray”, contendo 10.500 seqüências de ácido desoxirribonucléico codificado (cDNA) humano, compararam a expressão no leiomioma e no miométrio de 12 amostras provenientes de histerectomia. Vinte e cinco diferentes expressões gênicas foram identificadas (14 super-expressões e 11 sub-expressões) no leiomioma em relação ao miométrio. Alguns genes 
correlacionados à angiogênese foram confirmados por RT-PCR, incluindo aqueles super-expressos (IGF2, ETRA, COL4A2) e sub-expressos (CTGF, CYR61). A alteração de genes relacionados à angiogênese no leiomioma, em comparação ao miométrio, poderia explicar a alteração histopatológica da microvasculatura desse tumor, reduzida em relação ao miométrio normal.

Wang et al. (2003) estudaram leiomioma e miométrio de sete pacientes durante a fase proliferativa do ciclo menstrual, utilizando o HUGeneFL6800 "Microarray". A comparação dos pares de amostras revelou 68 genes com significativa diferença, sendo 23 super-expressos e 45 subexpressos no leiomioma em relação ao miométrio adjacente. Nesse estudo, os autores destacaram a importância dos fatores de crescimento e dos receptores hormonais, como o IGF-2 e os receptores de estrogênio (ER) $\alpha / \beta$, respectivamente. Além disso, genes relacionados à produção de colágeno, como gene pró-alfa (III) colágeno e pró-alfa (I) colágeno, apresentaram-se aumentados em relação ao miométrio, enquanto a proteína extracelular \$1-5 achava-se diminuída, indicando forte papel de componentes da MEC na gênese e no crescimento do leiomioma uterino.

Skubitz e Skubitz (2003) compararam 20 leiomiomas, 46 amostras de miométrio e 18 amostras de outro tecido, utilizando a plataforma Affymetrix U95A Gene Chip, contendo 12.000 genes e 48.000 seqüências expressas conhecidas (EST). Verificaram que 96 fragmentos conhecidos de genes (78 genes independentes) e 149 EST estavam super-expressos e 358 EST subexpressos no leiomioma, comparativamente ao miométrio. 
Ahn et al. (2003) rastrearam 17.000 genes em amostras de leiomioma e miométrio de seis pacientes coreanas, utilizando o Gene Track Human cDNA HSVC 307 chip (Genomictree, Inc., Korea), eletroforese em gel bidimensional e análise por classificação funcional. Nesse estudo, 71 genes apresentaram alterações da expressão, sendo 21 super-expressos e 50 subexpressos. Os autores relataram também a expressão dos genes relacionados à adesão e mobilidade celular, organogênese, regulação enzimática, atividade de moléculas estruturais e resposta a estímulos externos funcionais. Apenas os genes ligados à atividade de canais de ácidos nucléicos tiveram expressão gênica aumentada.

Catherino et al. (2003b) relataram a análise de 33.000 genes, utilizando a plataforma Affymetrix U133. Realizaram também PCR em Tempo Real, RT-PCR, Westhern Blot e imunoistoquímica para confirmar os dados obtidos por "microarray" e a super-expressão dos genes DLK, FZD2 e CD24. Em cinco pacientes com leiomioma, a super-expressão de DLK não foi confirmada. A partir desse estudo, sugeriram um protocolo para confirmar os dados obtidos por "microarray" (Figura 1). Três genes freqüentemente super-expressos (IGF2, CRABP2, CD24) e quatro sub-expressos (ADH1, DPT, ATF3, PTGER3) foram relatados nesse estudo. 


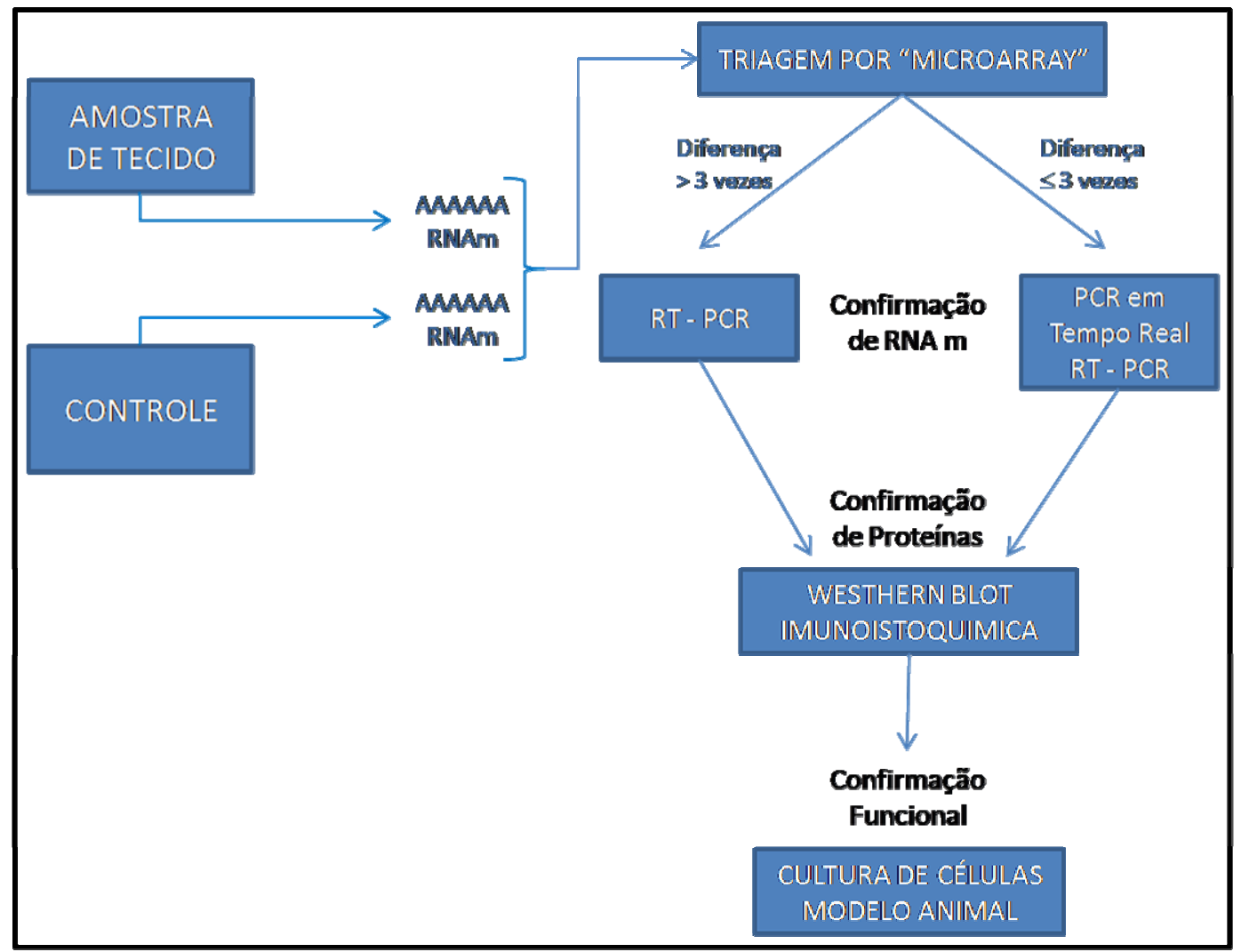

Figura 1 - Fluxograma proposto para confirmação de resultados do "microarray" (Catherino et al., 2003b)

Quade et al. (2004) descreveram os resultados da análise de 7.000 genes com o uso do Affymetrix HuFI Gene Chip em 4 amostras de miométrio normal, 7 leiomiomas e 5 leiomiossarcomas. Foram separados 146 genes por análise estatística como sendo diferencialmente expressos entre essas amostras. No entanto, nenhuma correlação pode ser feita entre eles quanto à análise funcional. Esses genes estão distribuídos por todo genoma com leve preponderância nos cromossomos $1 p$ e $2 q$. Os resultados sugerem ser distinta a etiopatogenia molecular do leiomioma e do leiomiossarcoma.

Hoffman et al. (2004) compararam tecido de miométrio normal e leiomioma em oito pacientes de variadas raças e idades submetidas a cirurgia por leiomiomas sintomáticos. Utilizando o Affymetrix U133A Gene 
Chip, encontraram 226 genes com expressão uma vez e meia, ou mais, acima da normalidade no leiomioma, comparativamente ao miométrio. A confirmação de 8 genes (CD44, DUSP1, DUSP6, EGFL6, ID3, SFRP1, SFRP4 e TRAIL) por PCR em tempo real demonstraram resultados similares àqueles do "microarray". Tais achados levaram os autores a afirmarem, diferentemente dos achados de Catherino et al. (2003a) que os dados do "microarray" da Affymetrix são confiáveis. Hoffman et al. (2004) discutiram, ainda, diferenças entre seu estudo, comparativamente aos de Tsibris et al. (2002), Catherino et al. (2003a), Skubitz e Skubitz (2003), Wang et al. (2003), e, principalmente entre as plataformas U95 e U133 da Affymetrix, delegando também aos softwares de análise dos dados e ao desenho dos trabalhos as diferenças encontradas.

Arslan et al. (2005) analisaram o perfil de 22.283 genes em amostras pareadas de leiomioma e miométrio adjacente, por meio da plataforma Affymetrix U133A. A expressão de 80 genes foi avaliada como alterada, sendo 14 super-expressos e 66 sub-expressos. Esse resultado foi comparado com dados da literatura já descritos. Essa análise comparativa destacou 8 genes descritos em 5 artigos anteriores (ADH1, ATF3, CRABP2, CYR61, DPT, GRIA2, IGF2, MEST), 11 genes foram referidos em 4 estudos prévios (ALDH1, CD24, CTGF, DCX, DUSP1, FOS, IGFBP6, PTGDS, PTGER3, TYMS) e 12 genes em três estudos prévios (ABCA, ANXA1, APM2, CCL2!, CDKN1A, CRMP1, EMP1, ESR1, FY, MAP3K5, TGFBR2, TIMP3). Quarenta genes descritos não foram citados por outros autores. 
Em resumo, os recentes estudos, apesar de terem diferença metodológica, no desenho e na casuística, convergem para determinados grupos de genes, supostamente relacionados à etiopatogenia do leiomioma uterino. Dessa forma, genes relacionados à proliferação celular, apoptose, angiogênese e acúmulo de MEC foram os mais descritos.

\subsection{Análogo agonista de GnRH e biologia molecular}

Diversos trabalhos utilizando a técnica de "microarray" têm auxiliado a elucidar a ação do análogo agonista do $\mathrm{GnRH}$ na etiopatogenia do leiomioma uterino. Dessa forma, Chegini et al. (2003), utilizando uma plataforma com 1.176 genes relacionados a câncer (Clontech Atlas Microarray), estudaram a expressão diferencial entre o leiomioma e o miométrio em 6 pacientes. Destas, 3 foram tratadas previamente à cirurgia com GnRHa. Nas pacientes não tratadas, 100 genes foram diferencialmente expressos, dos quais 18 super-expressos e 82 sub-expressos, no leiomioma em relação ao miométrio normal. Nas pacientes tratadas com $\mathrm{GnRHa}$, a expressão de 34 genes foi menor no leiomioma, enquanto no miométrio houve aumento da expressão de 27 genes e diminuição de 15 genes, em comparação ao miométrio das não tratadas. Esses dados demonstram, haver forte ação do GnRHa na expressão gênica, tanto do leiomioma, quanto do miométrio adjacente, reforçando, assim, observações clínicas que mostram haver maior regressão no miométrio em relação ao leiomioma 
uterino. Chegini et al. (2003) comentaram, nesse estudo, que a expressão diferencial de muitos genes nos leiomiomas estaria relacionada com a regulação do ciclo celular. Assim, o efeito do GnRHa sobre a proliferação celular e apoptose desempenharia papel relevante no crescimento desse tumor.

Luo et al. (2005) estudaram células cultivadas de musculatura lisa de leiomioma uterino e do miométrio, nas quais foi realizado "microarray" para avaliar a expressão gênica associada à terapia com $\mathrm{GnRHa}$ na fase secretória média do ciclo menstrual. No grupo não tratado, foram identificados 153 genes diferencialmente expressos nos leiomiomas em relação ao miométrio (82 super-expressos e 54 sub-expressos). No grupo tratado, detectaram-se 122 genes diferencialmente expressos nos leiomiomas em comparação ao miométrio (34 super-expressos e 67 subexpressos). Entretanto, o perfil gênico obtido difere bastante entre os dois grupos. Esse achado corrobora a teoria de que haveria uma ação distinta do GnRHa no leiomioma e no miométrio. Foi validada a expressão de interleucina 11 (IL 11), fator indutor de crescimento tumoral beta (TGF $\beta$ ), CITED2, Nur77, p27 e p57, dentre outros, utilizando PCR em tempo real, imunoistoquímica e Westhern Blot. Os autores discutiram a ação do GnRHa em diferentes funções celulares, mas, principalmente, na regulação do ciclo celular e na morte celular programada.

Chen et al. (2005) demonstraram, por PCR em tempo real, que há expressão de RNAm do receptor de GnRH em células cultivadas de leiomioma uterino. Relataram, ainda, que o tratamento de tais células com 
análogo antagonista de GnRH (Cetrorelix) reduz o número de células viáveis por indução de apoptose. Essa ação seria dose-dependente e indiretamente aferida pela decomposição de poli-adenosina-difosfato-ribose polimerase (PARP), conhecido marcador biológico de apoptose.

Todos esses dados denotam haver um número muito grande de genes relacionados à gênese do leiomioma uterino. Por esse motivo, assim como fizeram Arslan et al. (2005) em seu trabalho, compilamos os achados desses estudos acima revisados (Tsibris et al., 2002; Ahn et al., 2003; Catherino et al., 2003b; Skubitz; Skubitz, 2003; Wang et al., 2003; Hoffman et al., 2004; Quade et al., 2004; Arslan et al., 2005; Lee et al., 2005), restringindo nossa análise para os genes relacionados especificamente à apoptose e à proliferação celular. Como resultado, destacaram-se 7 genes relacionados, os quais foram citados em pelo menos três trabalhos (Tabela 2, p.23).

No entanto, ao compararmos os diferentes estudos descritos na literatura, depreende-se que a maioria analisou o leiomioma uterino e o miométrio adjacente sem o uso de GnRHa. Verifica-se haver grande heterogeneidade de resultados, daí o pequeno número de genes em comum que foram descritos.

\subsection{Aspectos clínicos relevantes para a análise da expressão gênica do leiomioma uterino}

Até 2003, na literatura, verifica-se que houve pouca preocupação em se descrever os aspectos clínicos da população selecionada para o estudo 
da análise gênica, sendo freqüente a inclusão de mulheres em diferentes faixas etárias, raça e coleta de material em fases distintas do ciclo menstrual. No entanto, Wang et al. (2003) referiram, pela primeira vez, a seleção da fase proliferativa do ciclo menstrual, o que foi seguido por Arslan et al. (2005).

Outros autores, como Gomes et al. (2007), descreveram haver maior atividade mitogênica no leiomioma uterino na fase secretória do ciclo menstrual, assim como alterações nos receptores de progesterona no leiomioma em relação ao miométrio adjacente. Esses achados sugerem maior atividade proliferativa nessa fase do ciclo.

Wei et al. (2005) e Pan et al. (2007) relataram, em seus estudos, diferenças da expressão gênica em pacientes afro-americanas em relação às caucasianas.

Wei et al. (2006) notaram alterações relacionadas à localização e ao tamanho dos nódulos de leiomiomas analisados.

A grande heterogeneidade de resultados das pesquisas realizadas até então e a pronunciada alteração da expressão gênica em diferentes populações, associados à escassez de estudos com controle de eventuais fatores confundidores, estimularam-nos a aprofundar os estudos sobre a etiopatogenia dessa afecção, em especial quanto às alterações gênicas, por meio de biologia molecular. 
Tabela 2 - Genes relacionados à apoptose e proliferação celular, com expressão gênica alterada no leiomioma uterino por "microarray"

\begin{tabular}{|c|c|c|c|c|c|c|c|c|c|c|c|}
\hline $\begin{array}{l}\text { Classe } \\
\text { funcional }\end{array}$ & Sigla & Gene & $\begin{array}{c}\text { Tsibris et } \\
\text { al., } 2002\end{array}$ & $\begin{array}{c}\text { Ahn et } \\
\text { al., } 2003 \\
\end{array}$ & $\begin{array}{c}\text { Wang et al., } \\
2003\end{array}$ & $\begin{array}{c}\text { Hoffman et } \\
\text { al., 2004 }\end{array}$ & $\begin{array}{l}\text { Arslan et } \\
\text { al., } 2005\end{array}$ & $\begin{array}{c}\text { Catherino } \\
\text { et al., 2004 }\end{array}$ & $\begin{array}{l}\text { Quade et } \\
\text { al., 2004 }\end{array}$ & $\begin{array}{c}\text { Skubitz; } \\
\text { Skubitz, 2003 } \\
\end{array}$ & $\begin{array}{c}\text { Lee et } \\
\text { al., } 2005 \\
\end{array}$ \\
\hline Apoptose & SFRP & Secreted frizzled-related protein 1 & 0 & 0 & 0 & - & 0 & 0 & 0 & 0 & 0 \\
\hline Apoptose & SFRP4 & Secreted frizzled-related protein 4 & 0 & 0 & 0 & - & 0 & 0 & 0 & 0 & 0 \\
\hline Apoptose & MAP3K5 & Mitogen activated protein kinase kinase kinase 5 & - & 0 & - & - & - & 0 & 0 & 0 & 0 \\
\hline Apoptose & MST4 & Mst3 and SOK1-related kinase & 0 & 0 & 0 & - & 0 & 0 & 0 & 0 & 0 \\
\hline Apoptose & GADD45B & Growth arrest and DNA-damageinducible,beta & 0 & 0 & 0 & - & 0 & 0 & 0 & 0 & 0 \\
\hline Apoptose & TNFSF10 & Tumor necrosis factor (ligand) superfamily (TRAIL) & 0 & 0 & - & - & 0 & 0 & 0 & 0 & 0 \\
\hline Apoptose & MCL1 & Myeloid cell leukemia sequence 1 & 0 & 0 & 0 & - & - & 0 & 0 & 0 & 0 \\
\hline $\begin{array}{l}\text { Proliferação } \\
\text { celular } \\
\text { Proliferação }\end{array}$ & IGF2 & Insulin-like growth factor 2 & + & + & + & + & + & + & 0 & + & + \\
\hline $\begin{array}{l}\text { celular } \\
\text { Proliferação }\end{array}$ & TGFB1 & Transforming growth factor, beta induced & 0 & 0 & + & + & 0 & 0 & 0 & 0 & 0 \\
\hline $\begin{array}{l}\text { celular } \\
\text { Proliferação }\end{array}$ & CREG & Cellular repressor of $\mathrm{E} 1 \mathrm{~A}$ stimulated genes & 0 & 0 & 0 & + & 0 & 0 & 0 & 0 & + \\
\hline $\begin{array}{l}\text { celular } \\
\text { Proliferação }\end{array}$ & TGFBR2 & Transforming growth factor, beta receptor II & + & 0 & 0 & + & 0 & 0 & + & 0 & 0 \\
\hline $\begin{array}{l}\text { celular } \\
\text { Proliferação }\end{array}$ & BTG2 & BTG family, member 2 & 0 & 0 & 0 & + & 0 & 0 & 0 & 0 & 0 \\
\hline $\begin{array}{l}\text { celular } \\
\text { Proliferação }\end{array}$ & DUSP6 & Dual specificity phosphatase & 0 & + & 0 & + & 0 & 0 & 0 & 0 & 0 \\
\hline $\begin{array}{l}\text { celular } \\
\text { Proliferação }\end{array}$ & ADAMTS1 & A disintegrin-like and metalloprotease & 0 & 0 & 0 & + & 0 & 0 & 0 & 0 & 0 \\
\hline $\begin{array}{l}\text { celular } \\
\text { Proliferação }\end{array}$ & VEGF & Vascular endothelial growth factor & 0 & 0 & 0 & + & 0 & 0 & 0 & 0 & 0 \\
\hline $\begin{array}{l}\text { celular } \\
\text { Proliferação }\end{array}$ & GPNMB & Glycoprotein (transmembrane) $\mathrm{nmb}$ & 0 & 0 & 0 & + & 0 & 0 & 0 & 0 & 0 \\
\hline $\begin{array}{l}\text { celular } \\
\text { Proliferação }\end{array}$ & CTGF & Connective tissue growth factor & 0 & + & 0 & + & + & 0 & + & 0 & 0 \\
\hline $\begin{array}{l}\text { celular } \\
\text { Proliferação }\end{array}$ & CAPRI & Ca2 promoted Ras inactivator & 0 & 0 & 0 & + & 0 & 0 & 0 & 0 & 0 \\
\hline $\begin{array}{l}\text { celular } \\
\text { Proliferação }\end{array}$ & TM4SF1 & Transmembrane 4 superfamily member 1 & 0 & 0 & 0 & + & + & 0 & 0 & 0 & 0 \\
\hline $\begin{array}{l}\text { celular } \\
\text { Proliferação }\end{array}$ & EMP1 & Epithelial membrane protein 1 & 0 & + & 0 & + & 0 & 0 & 0 & 0 & 0 \\
\hline $\begin{array}{l}\text { celular } \\
\text { Proliferação }\end{array}$ & IGFBP6 & Insulin-growth factor binding protein 6 & + & 0 & 0 & + & + & 0 & 0 & + & 0 \\
\hline $\begin{array}{l}\text { celular } \\
\text { Proliferação }\end{array}$ & C8FW & Phosphoprotein regulated by mitogenic pathways & 0 & 0 & 0 & + & 0 & 0 & 0 & 0 & 0 \\
\hline celular & CYR61 & Cysteine-rich, angiogenic inducer 61 & + & + & 0 & + & + & 0 & + & 0 & + \\
\hline
\end{tabular}

+ : Citado (super expresso); - : Citado (sub-expresso); 0: Não Citado; Descata-se em vermelho (+, - ) : genes com 3 ou mais Citações 
2 OBJETIVOS 
Analisar, por técnica de "microarray", os efeitos do análogo agonista do GnRH na expressão gênica do leiomioma uterino de mulheres no período reprodutivo.

$>$ Confirmar, com técnica de PCR em tempo real, o resultado obtido por "microarray" em genes diferencialmente expressos selecionados. 


\subsection{Pacientes}

Após aprovação do projeto pela Comissão de Ética (Anexo 1), foram selecionadas 89 pacientes atendidas no Setor de Leiomioma Uterino da Divisão de Clínica Ginecológica do Hospital das Clínicas da Faculdade de Medicina da Universidade de São Paulo (HC-FMUSP).

\subsubsection{Critérios de inclusão}

Raça negra;

Idade entre 20 e 45 anos;

$>$ Ciclos hipermenorrágicos;

Diagnóstico clínico e ultra-sonográfico de leiomioma uterino; > Indicação para tratamento cirúrgico.

\subsubsection{Critérios de exclusão}

$>$ Pacientes com coagulopatias;

Afecções genitais e extra-genitais pré-malignas ou malignas associadas;

$>$ Uso de estrogênio ou progestagênio nos últimos 30 dias. 


\subsubsection{Fluxograma do estudo}

As pacientes receberam todas as informações pertinentes ao estudo e assinaram o termo de consentimento pós-informado (Anexo 2). Todas seguiram o plano de atendimento ambulatorial descrito na Figura 2.

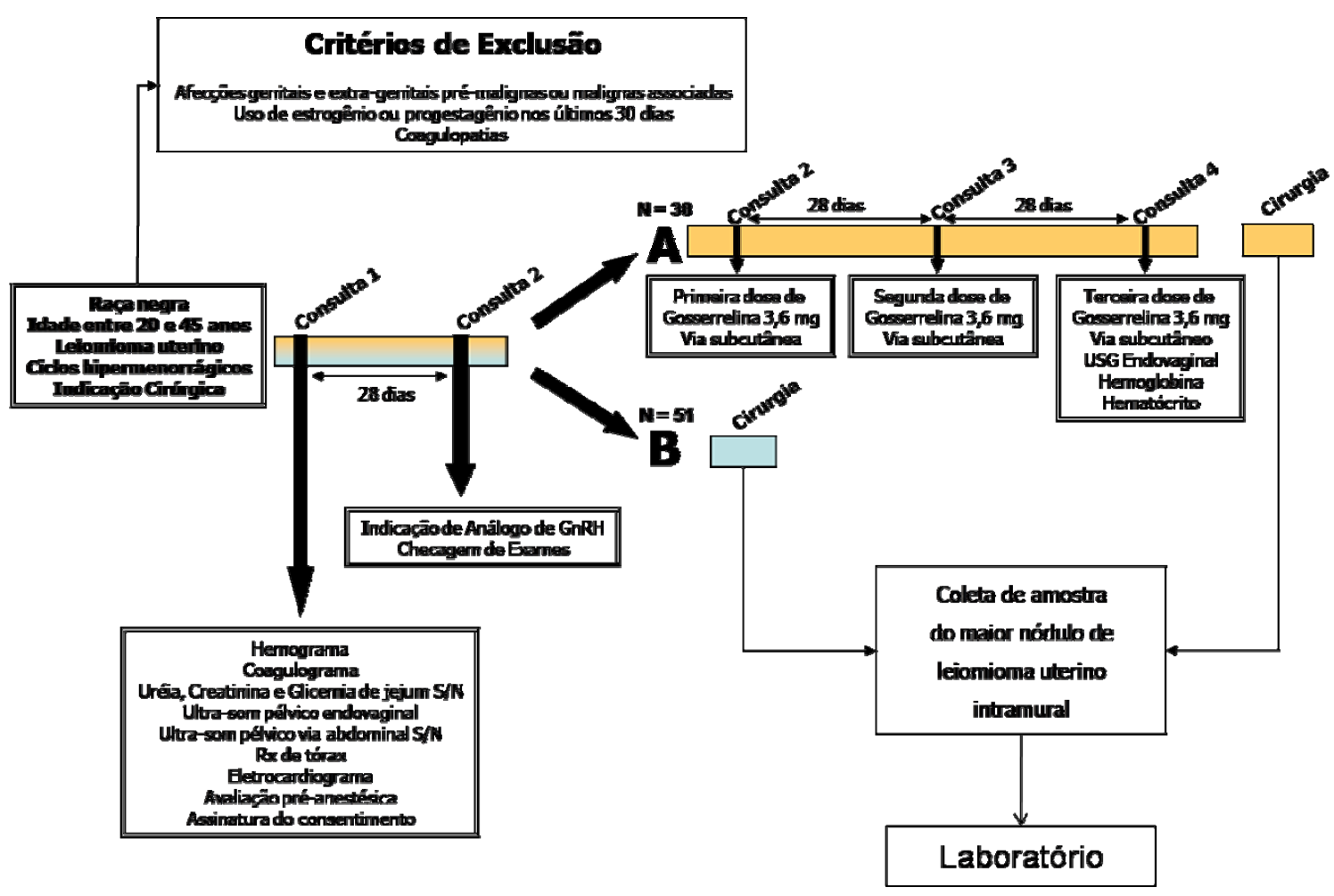

Figura 2 - Fluxograma do plano de atendimento ambulatorial

Consulta 1: Anamnese completa; exames físico geral e ginecológico e coleta de citologia oncótica cervicovaginal. Solicitação de exames subsidiários de rotina: hemoglobina e hematócrito, coagulograma, uréia, creatinina, sódio, potássio e glicemia de jejum, conforme a necessidade préoperatória (comorbidades clínicas associadas). Exame ultra-sonográfico pélvico (endovaginal e abdominal), radiografia de tórax, eletrocardiograma e 
avaliação pré-anestésica.

Consulta 2: Após avaliar os exames realizados e conforme os critérios de inclusão, as pacientes foram alocadas em dois grupos, a saber:

Grupo A (Tratado) $(\mathrm{n}=38)$ : Pacientes que receberam GnRHa (gosserrelina), na dose de 3,6mg, a cada 28 dias, por 3 meses consecutivos, por via subcutânea, previamente à cirurgia (Anexo 3);

Grupo B (Não-Tratado) ( $n=51)$ : Pacientes submetidas ao tratamento cirúrgico sem terapia com GnRHa (Anexo 4).

A inclusão das pacientes, nesses grupos, envolveu critérios clínicos, como anemia, pois, está bem estabelecido que a terapia pré-miomectomia com GnRHa colabora para o tratamento do quadro anêmico e reduz a necessidade de transfusão sangüínea (Lethaby et al., 2001).

Com relação às pacientes alocadas no Grupo B (Não-Tratado) e com exames pré-operatórios normais, foi indicada, de imediato, a cirurgia. Já para as do Grupo A (Tratado), foi administrada a primeira dose de gosserrelina, 3,6 mg por via subcutânea, as outras duas doses foram programadas em intervalos de 28 dias.

Consulta 3: As pacientes do Grupo A (Tratado) receberam a segunda dose de gosserrelina, 3,6 mg, por via subcutânea.

Consulta 4: As pacientes do Grupo A (Tratado) receberam a terceira dose de gosserrelina, 3,6 mg, por via subcutânea, e foram solicitados ultrasom pélvico (endovaginal e abdominal) e determinação de hemoglobina e hematócrito. 
Tratamento cirúrgico - as pacientes dos Grupos A (Tratado) e B (NãoTratado) foram submetidas à miomectomia.

No ato intra-operatório, foi colhida amostra do maior nódulo de leiomioma intramural. O material foi acondicionado em RNA Rolder (meio líquido para preservação de RNA) para transporte. No laboratório, o material foi macerado e conservado $\mathrm{a}-80^{\circ} \mathrm{C}$.

Dentro de cada grupo, foram selecionadas 10 amostras observando-se os seguintes critérios: mulheres nulíparas; amostra colhida exatamente na segunda fase do ciclo menstrual no Grupo B (a partir do $14^{\circ}$ dia do ciclo menstrual); nódulo maior acima de $3,0 \mathrm{~cm}$ e volume uterino inicial superior a 300 cc (Figura 3).

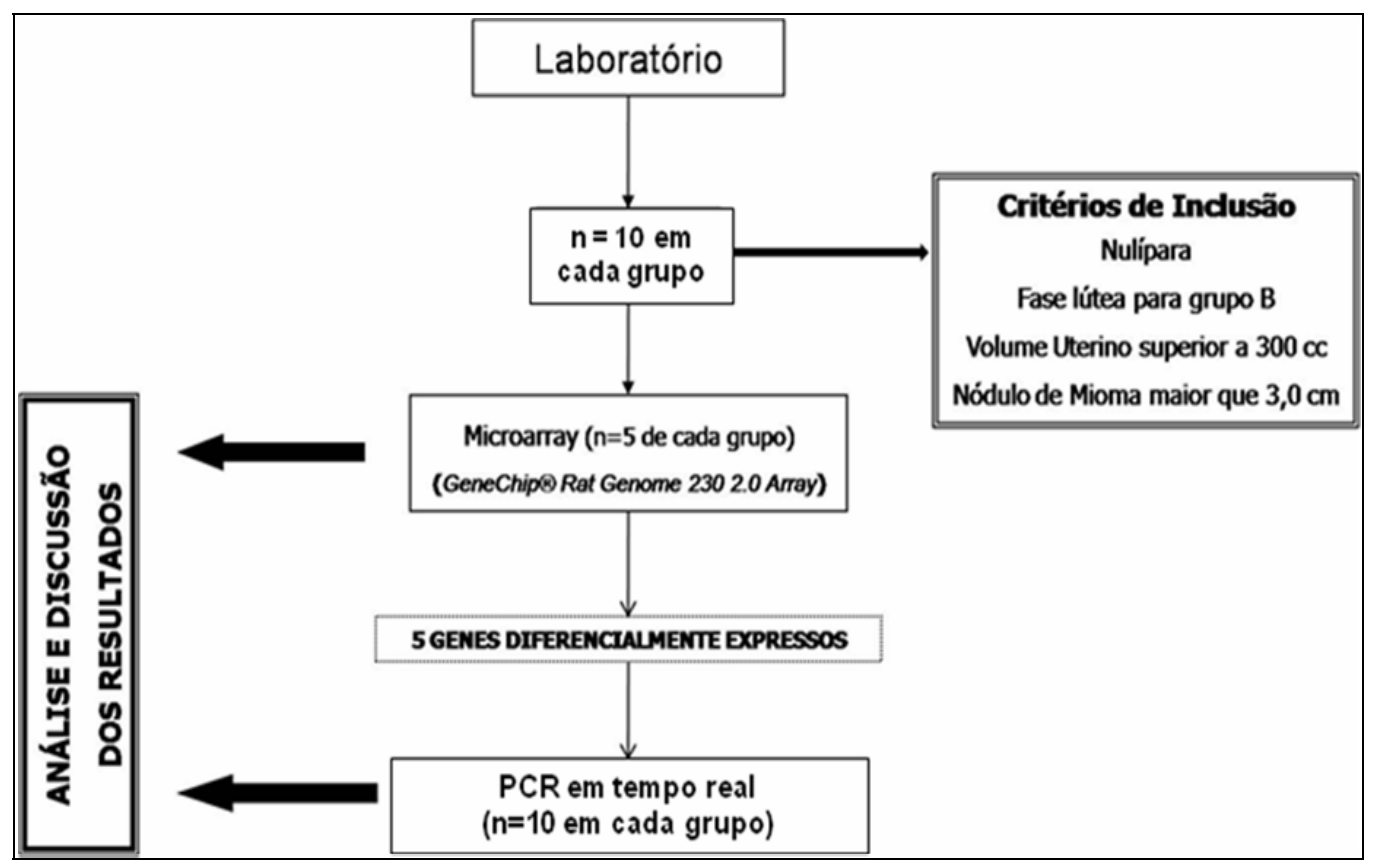

Figura 3 - Fluxograma: análise laboratorial 
Após a análise das 10 amostras selecionadas, obtivemos os seguintes dados:

No Grupo A (Tratado), a idade média foi de 34,1 anos (+/- 4,77 anos); IMC médio $25,6 \mathrm{Kg} / \mathrm{m}^{2}\left(+/-4,96 \mathrm{Kg} / \mathrm{m}^{2}\right)$; média do maior nódulo tumoral 83,6 mm (+/- 23,7 mm); média do número de nódulos excisados no procedimento cirúrgico $8,4(+/-3,75)$, volume uterino médio pré-análogo 838,50 cc (+/- 435,7 cc); volume uterino médio pós-análogo 538,29 cc (+/- 335,56 cc); redução média do volume uterino após tratamento com análogo $37,22 \%(+/-16,25 \%)$; valor médio de hemoglobina pré-análogo $10,74 \mathrm{mg} / \mathrm{dl}(+/-1,7 \mathrm{mg} / \mathrm{dl}) ;$ valor médio de hematócrito 34,34 \% (+/- 4,06 \%); acréscimo médio de hemoglobina após tratamento com análogo de $1,74 \mathrm{mg} / \mathrm{dl}(+/-0,76 \mathrm{mg} / \mathrm{dl})$ e acréscimo médio de hematócrito após tratamento com análogo 3,64 mg/dl (+/-1,86 mg/dl) (Anexo 5).

No Grupo B (Não-Tratado) a idade média foi de 34 anos (+/- 2,87 anos); IMC médio $26,29 \mathrm{Kg} / \mathrm{m}^{2}\left(+/-4,77 \mathrm{Kg} / \mathrm{m}^{2}\right)$; dia médio do ciclo menstrual 22,4 dias (+/- 5,44 dias); média do maior nódulo tumoral $66,50 \mathrm{~mm}$ (+/- 25,39 mm); média do número de nódulos excisados no procedimento cirúrgico $8,4(+/-3,53)$; volume uterino médio 529,35 cc (+/- 274,14 cc); valor médio de hemoglobina 12,66 mg/dl (+/- 2,03 mg/dl) e valor médio de hematócrito 39,55\% (+/- 5,54 \%) (Anexo 6).

Após análise descritiva de todas as variáveis, foi realizada análise comparativa entre os Grupos A (Tratado) e B (Não-Tratado). Para tanto, foram utilizados os teste $\mathrm{t}$ de Student e teste não-paramétrico de Mann- 
Whitney, pois a suposição de normalidade do número de nódulos foi rejeitada. O nível de significância utilizado para os testes foi de $5 \%(p<0,05)$.

Pelo teste t de Student, os Grupos A (Tratado) e B (Não-Tratado) não diferiram em relação à idade $(p=0,955)$, ao IMC $(p=0,754)$, ao maior nódulo $(p=0,137)$ e ao volume uterino $(p=0,074)$. Por meio do teste não-paramétrico de Mann-Whitney, também não diferiram quanto ao número de nódulos $(p=0912)($ Tabela 3$)$.

As amostras de leiomiomas coletadas foram processadas para extração de RNA, sendo 5 de cada grupo analisados por técnica de “microarray" pela plataforma Affymetrix (GeneChip® Human Genome U133 Plus 2.0 Array)

A partir dos resultados do "microarray", obtivemos um panorama das alterações genéticas presentes em nossa amostra, sendo possível correlacionar alterações dos leiomiomas tratados e não tratados com análogo de $\mathrm{GnRH}$.

Tabela 3 - Análise estatística comparativa entre os Grupos A (tratado) e B (não tratado)

\begin{tabular}{|c|c|c|c|c|c|c|c|c|c|}
\hline Variável & Grupo & $\mathbf{N}$ & Média & DP & Mínimo & Máximo & Mediana & $\mathbf{p}$ & \\
\hline \multirow{2}{*}{$\begin{array}{l}\text { Idade } \\
\text { (anos) }\end{array}$} & A & 10 & 34,10 & 4,77 & 26,00 & 40,00 & 35,00 & \multirow{2}{*}{0,955} & \multirow{2}{*}{$\begin{array}{l}\text { Teste t de } \\
\text { Student }\end{array}$} \\
\hline & $B$ & 10 & 34,00 & 2,87 & 29,00 & 38,00 & 34,00 & & \\
\hline \multirow{2}{*}{ IMC $\left(\mathrm{Kg} / \mathrm{m}^{2}\right)$} & A & 10 & 25,60 & 4,96 & 19,31 & 36,94 & 25,52 & \multirow{2}{*}{0,754} & \multirow{2}{*}{$\begin{array}{l}\text { Teste t de } \\
\text { Student }\end{array}$} \\
\hline & $B$ & 10 & 26,29 & 4,77 & 21,88 & 37,92 & 24,76 & & \\
\hline \multirow{2}{*}{$\begin{array}{l}\text { Maior } \\
\text { Nódulo } \\
(\mathrm{mm})\end{array}$} & A & 10 & 83,60 & 23,70 & 55,00 & 130,00 & 83,00 & \multirow{2}{*}{0,137} & \multirow{2}{*}{$\begin{array}{l}\text { Teste t de } \\
\text { Student }\end{array}$} \\
\hline & B & 10 & 66,50 & 25,39 & 30,00 & 100,00 & 70,00 & & \\
\hline \multirow{2}{*}{$\begin{array}{l}\text { Número de } \\
\text { Nódulos }\end{array}$} & $A$ & 10 & 8,40 & 3,75 & 4,00 & 17,00 & 8,00 & \multirow{2}{*}{0,912} & \multirow{2}{*}{$\begin{array}{l}\text { Teste não- } \\
\text { paramétrico } \\
\text { de Mann- } \\
\text { Whitney }\end{array}$} \\
\hline & $B$ & 10 & 8,40 & 3,53 & 3,00 & 15,00 & 8,00 & & \\
\hline
\end{tabular}

n: número de amostras; DP: Desvio-Padrão; ${ }^{*} \mathrm{p}<0,05$ (significância estatística) 
A seguir, foram selecionados 5 desses genes, embasados nos dados da literatura, com classificação funcional conhecida, que se mostraram diferencialmente expressos entre os Grupos A (Tratado) e B (Não Tratado). Em seguida, procedeu-se à confirmação do resultado por PCR em tempo real, aplicado para as 10 amostras de cada grupo, incluindo os casos analisados por "microarray", seguindo sempre os mesmos critérios de seleção (nulíparas, material colhido na segunda fase do ciclo menstrual no Grupo B, nódulo maior acima de $3,0 \mathrm{~cm}$ e volume uterino inicial superior a $300 \mathrm{cc}$ ) (Figura 3).

\subsection{Métodos}

\subsubsection{Técnica de "Microarray"}

\subsubsection{Extração de RNA}

O RNA total do tecido de leiomioma foi extraído com reagente Trizol, conforme protocolo adaptado no Laboratório de Biologia Molecular/ Setor Proteômica/ Lim 02 - FMUSP.

Os fragmentos de tecido foram macerados manualmente (com gral e pistilo) em banho de nitrogênio líquido para obtenção de 100 a 400mg de peso, e acondicionados em microtubos estéreis e livres de nucleases. Ao material macerado de $100 \mathrm{mg}$, foi adicionado $1000 \mu \mathrm{l}$ de Trizol Reagente 
(Invitrogen) para lise celular, homogeneizando-se manualmente até que o material esteja totalmente dissolvido. Após esta etapa, o material foi incubado em temperatura ambiente por 10 minutos.

A este material foi acrescentado 200ul de Clorofórmio (Merck) e agitado em vórtex até que a amostra estivesse com aspecto leitoso. A seguir, as amostras foram deixadas em repouso por 10 minutos à temperatura ambiente, quando houve a quebra da membrana nuclear e separação do DNA genômico das proteínas e do RNA, reduzindo, assim, a viscosidade do lisado.

Após, as amostras serem submetidas à centrifugação (Eppendorf/ Centrifuge $5804 \mathrm{R}$ ) a $12000 \mathrm{rpm}$, por 15 minutos, à $4^{\circ} \mathrm{C}$, separando as fases de DNA, proteínas e RNA, a fase aquosa transparente foi transferida para novo microtubo estéril, livre de nucleases, adicionando-se $500 \mu l$ de Ispropanol gelado (Merck) e invertendo-se o microtubo, manualmente, várias vezes.

As amostras foram incubadas por 45 minutos em banho de gelo para precipitar o material. Após, as amostras foram submetidas à centrifugação a $12000 \mathrm{rpm}$, por 15 minutos, à $4^{\circ} \mathrm{C}$. O sobrenadante foi desprezado e, ao pellet restante, foi adicionado $1000 \mu$ l de Etanol $70 \%$ gelado (Álcool Etílico Merck), homogeneizando-se manualmente. Novamente, as amostras foram centrifugadas a $12000 \mathrm{rpm}$, por 15 minutos, à $4^{\circ} \mathrm{C}$ e o sobrenadante foi desprezado. O pellet restante secou em temperatura ambiente durante 30 minutos, e após, foi adicionado $50 \mu \mathrm{l}$ de água DEPC 0,01\% (Dietil Pirocarbonato - Sigma). 
As amostras foram armazenadas em freezer a $-80^{\circ} \mathrm{C}$. Para a estabilidade e preservação das amostras, estas foram armazenadas em alíquotas, o que evita a degradação do material a cada descongelamento. Com este método, foi possível obter um RNA de boa qualidade e concentração, com validade de 2 anos. A integridade do RNA foi verificada em gel de agarose 1\% (Figura 4). A quantificação do RNA nas amostras foi obtida por análise em espectrofotômetro com absorbância em 260nm e 280nm, diluição de 1:40 e razão 2. A concentração de RNA total é dada em $\mu \mathrm{g} / \mathrm{ml}$, onde $\mu \mathrm{g} / \mathrm{ml}=$ OD260 $X$ fator de diluição $\times 40 \mu \mathrm{g} / \mathrm{ml}$.

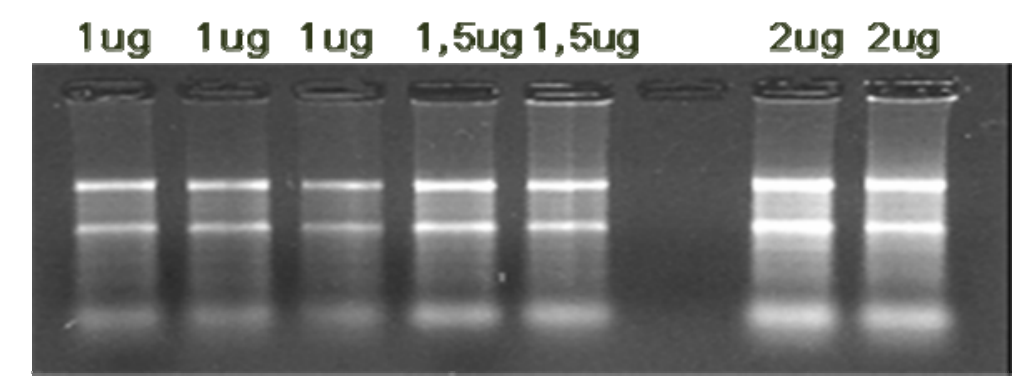

Figura 4 - Verificação da integridade do RNA em gel de agarose $1 \%$

\subsubsection{Síntese e marcação do RNA complementar}

O RNA total ( $1 \mu \mathrm{g}$ a $15 \mu \mathrm{g})$, obtido a partir do tecido de interesse, foi primeiramente convertido em cDNA dupla-fita, através de uma reação de transcriptase reversa. O produto final da reação de síntese de cDNA foi purificado com a utilização do sistema GeneChip® Sample Cleanup Module, seguindo-se rigorosamente as instruções do fabricante. Em seguida, o cDNA purificado serve de molde para uma reação de transcrição in vitro, na 
presença de nucleotídeos marcados com biotina, resultando em cRNA (RNA complementar) biotinilado. Todas as etapas foram realizadas utilizando-se o Kit GeneChip ${ }^{\circledR}$ One-Cycle Target Labeling and Control Reagents (Affymetrix Inc., Santa Clara, CA, USA). O cRNA biotinilado foi então purificado e, posteriormente, teve sua integridade e quantidade checada através de eletroforese em um gel de agarose.

\subsubsection{Fragmentação do cRNA marcado com biotina}

O cRNA marcado com biotina foi, então, fragmentado através da adição de tampão de Fragmentação 5X (Affymetrix Inc., Santa Clara, CA, USA). Este tampão é otimizado para fragmentar moléculas de cRNA completas em fragmentos de 35 a 200 bases por hidrólise induzida por metal.

\subsubsection{Hibridização do cRNA fragmentado}

Ao cRNA fragmentado, foi adicionada uma solução de hibridização preparada, utilizando-se os reagentes do Kit GeneChip ${ }^{\circledR}$ Hybridization, Wash and Stain Kit(Affymetrix Inc., Santa Clara, CA, USA). A solução contendo o cRNA da amostra em análise foi, então, colocada no chip (GeneChip® Rat Genome 2302.0 Array), o qual foi acondicionado em forno de hibridação a $45^{\circ} \mathrm{C}$, e hibridados por 16 horas com rotação de 60 rpm. 


\subsubsection{Lavagem, coloração e leitura do array}

Após o tempo de hibridização, o chip foi, então, colocado na estação de lavagem e coloração na estação fluídica (GeneChip ${ }^{\circledR}$ Fluidics Station 400), onde o excesso de oligonucleotídeos não-hibridados foi retirado da lâmina e o cRNA marcado com biotina. Sendo efetivamente ligado às sondas do chip, o cRNA foi corado com uma solução contendo um conjugado de estreptavidina fluorescente.

Após o procedimento de hibridização, a lâmina foi analisada através do GeneChip® Scanner 3000 7G, conectado ao GeneChip® Operating Software, o qual analisa os dados e quantifica a intensidade da fluorescência em cada ponto. O sinal gerado representa a ligação do cRNA originado da amostra original com a sonda no array, e tende a ser proporcional à abundância do cRNA presente, até certa concentração de transcritos. A quantificação do sinal permite que a expressão de milhares de genes seja comparada entre diferentes condições experimentais.

A captura das imagens e análises iniciais das hibridações foram feitas com o software MicroArray Suite 5.0 - MAS (Affymetrix), e os arquivos gerados foram salvos em formato (.cel).

\subsubsection{PCR em tempo real}

Para confirmar os resultados obtidos pelo "microarray" foram selecionados os seguintes genes: 
- WIF1 (WNT fator inibidor 1);

EGR1 (Resposta a crescimento inicial 1);

SULF2 (Sulfatase 2);

HMGN1 (Nucleossoma vinculado a grupo de alta mobilidade, domínio1);

CYR61 (Indutor angiogênico rico em cisteína, 61).

O gene GAPDH (Glyceraldehyde-3-phosphate dehydrogenase) foi selecionado como gene de referência, ou calibrador. O gene de referência é normalmente utilizado para corrigir artefatos decorrentes de variações: na eficiência da transcrição reversa, na quantificação de RNA inicial, em erros de pipetagem, dentre outras. Será utilizado para normalizar os níveis de expressão dos genes de interesse.

O RNA total foi quantificado utilizando o espectofotômetro Nanodrop1000 e teve sua qualidade verificada através do equipamento Agilent Bioanalyzer 2100. Um total de 1.0ug de RNA total por amostra foi submetido à reação de transcrição reversa utilizando o kit: High Capacity cDNA Reverse Transcription Kit (Applied Biosystems: 4368814), de acordo com as recomendações do fabricante.

O produto de cDNA foi então submetido à reação de PCR em tempo real, utilizando o sistema TaqMan®. Os primers e as sondas utilizadas para a quantificação da expressão dos genes de interesse foram sintetizadas pelo sistema Assay by Design (Applied Biosystems). Os respectivos números de referência para as mesmas são:

WIF1: $A B I$ assay ID:Hs00183662_ml; 
EGR1: $A B I$ assay ID: Hs00152928_m1;

SULF2 : ABI assay ID: Hs00378697_m1;

HMGN1: ABI assay ID: Hs01633572_g;

CYR61: ABI assay ID: Hs00155479_m1;

$>$ GAPDH (Gliceraldeido - 3 - fosfato dehidrogenase): $A B I$ assay ID:Hs99999905_m1.

Todas as amostras foram analisadas em triplicata tanto para os genes de interesse, como para o gene GAPDH. Cada reação consistiu de: 5 ul (cDNA) + 20 ul de TaqMan Universal PCR Master Mix (Applied Biosystems: 4304437), primers e 6-FAM labeled probe.

Condições da reação:

Estágio $1: 50^{\circ} \mathrm{C}$ por 2 minutos;

Estágio 2: $95^{\circ} \mathrm{C}$ por 10 minutos;

Estágio 3: $95^{\circ} \mathrm{C}$ por 15 segundos, $60^{\circ} \mathrm{C}$ por 1 minuto (40 ciclos).

Os dados são expressos como valor de Ct (ciclo limiar), o qual é definido como o número de ciclos, no qual a fluorescência emitida ultrapassa um limiar. O limiar é um ponto definido pelo pesquisador e obrigatoriamente deve estar na faixa em que a quantidade de fluorescência gerada pela amplificação das amostras torna-se significativamente maior que a fluorescência de base. O limiar é definido na fase exponencial da reação de PCR, quando a quantidade de produto formada traduz de forma satisfatória a concentração inicial de fitas molde (mRNA/cDNA) amplificadas pela reação. 
O valor de Ct é inversamente proporcional à quantidade de RNA inicial. De uma maneira geral, quanto maior o número de ciclos necessários para atingir o limiar, menor a quantidade de cDNA presente no início do experimento, e conseqüentemente menor a expressão do gene em estudo.

\subsection{Método estatístico}

Para análise estatística da técnica de "Microarray", primeiramente, os dados foram normalizados com o intuito de reduzir ruídos e variações não biológicas, utilizando-se o programa GeneChip ${ }^{\circledR}$ Operating Software, (Affymetrix Inc., Santa Clara, CA, USA). O software de análise secundário, DNA-Chip Analyzer (dChip) (www.dchip.org), foi usado para a realização de análises comparativas, através do teste t ou Teste de Análise de Variância (ANOVA), seguidas de correções estatísticas para múltiplos testes, utilizando-se o método conhecido como False Discovery Rate (FDR). A partir dos resultados obtidos, será possível identificar genes diferencialmente expressos nas distintas condições experimentais, agrupá-los de acordo com os seus níveis de expressão, e categorizá-los de acordo com suas funções biológicas.

A análise estatística dos resultados do PCR, foi realizada utilizando o software SPSS v16.0 (Pacote estatístico para ciências sociais). Para comparação entre os grupos foi utilizado $o$ teste $t$ para amostras independentes. 
4 RESULTADOS 


\subsection{Técnica de Microarray}

Foi realizada análise por "microarray" em 5 amostras aleatórias de cada grupo.

Grupo A (Tratado): M1, M3, M18, M25, M33.

Grupo B (Não-Tratado): M14, M15, M16, M68, M70.

\subsubsection{Normalização}

Os Gráficos 1 e 2 mostram as 10 hibridizações analisadas, com suas distribuições de intensidades já normalizadas em relação à intensidade média.

Gráfico 1 - Distribuições de intensidade das lâminas hibridizadas com amostras do Grupo A (Tratado)

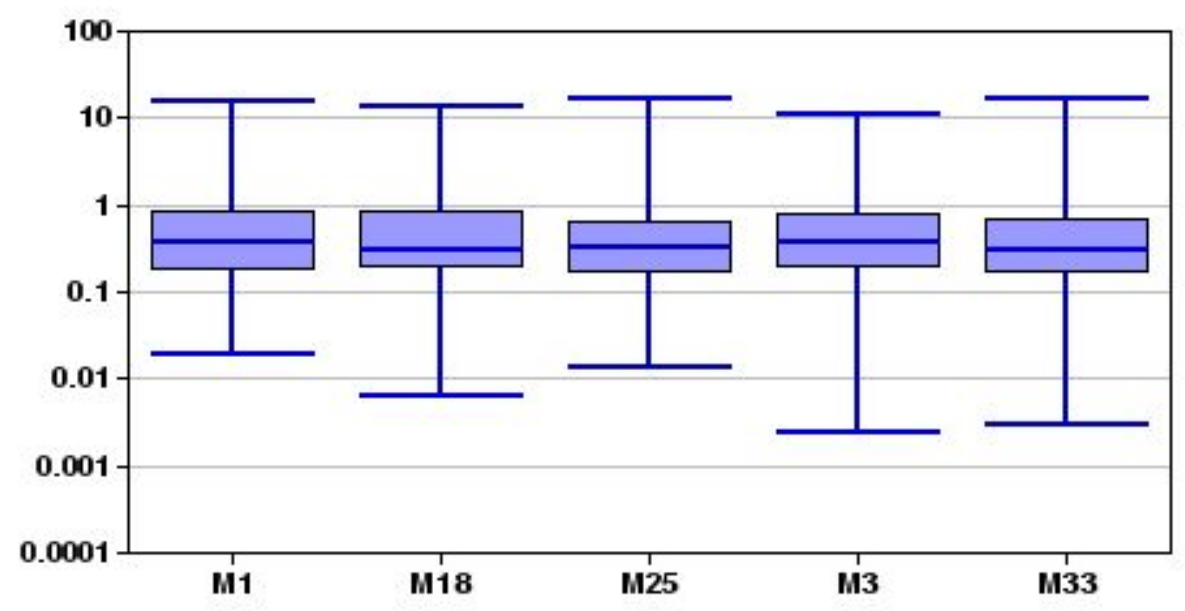


Gráfico 2 - Distribuições de intensidade das lâminas hibridizadas com amostras do Grupo B (Não-Tratado)

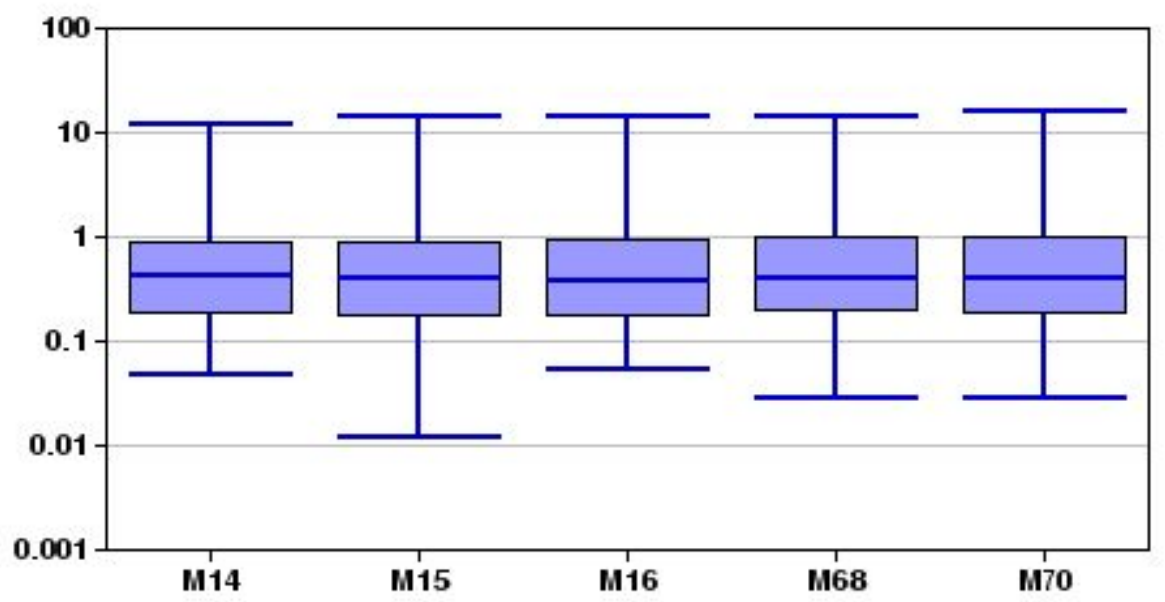

\subsubsection{Genes diferencialmente expressos}

Do total de 47.000 genes transcritos analisados, comparativamente, entre os Grupos A (Tratado) e B (Não-Tratado), representando em torno de 38.500 genes humanos já caracterizados, obtivemos um total de 174 transcritos diferencialmente expressos. Desses, 70 achavam-se superexpressos, representando 33 genes com função conhecida (Tabela 4), e 104 sub-expressos, correspondendo a 65 genes com função conhecida (Tabela $5)$. 
Tabela 4 - Lista de genes super-expressos no Grupo A (Tratado) em relação ao Grupo B (Não-Tratado)

\begin{tabular}{|c|c|c|}
\hline Genes super-expressos & Identidade & Taxa \\
\hline Aldehyde dehydrogenase 1 family, member A2 & ALDH1A2 & 3.89 \\
\hline Forkhead box L2 & FOXL2 & 2.54 \\
\hline Protocadherin 7 & $\mathrm{PCDH} 7$ & 2.38 \\
\hline Tandem C2 domains, nuclear & $\mathrm{TC} 2 \mathrm{~N}$ & 2.36 \\
\hline Dihydropyrimidinase-like 4 & DPYSL4 & 2.28 \\
\hline Cysteine-rich, angiogenic inducer, 61 & CYR61 & 2.20 \\
\hline Beta-1,3-N-acetylgalactosaminyltransferase 2 & B3GALNT2 & 2.14 \\
\hline Apolipoprotein L domain containing 1 & APOLD1 & 2.14 \\
\hline Early growth response 1 & EGR1 & 2.06 \\
\hline $\begin{array}{l}\text { Microtubule associated monoxygenase, calponin and LIM domain } \\
\text { containing } 1\end{array}$ & MICAL1 & 2.04 \\
\hline Leucine-rich repeat kinase 1 & LRRK1 & 1.98 \\
\hline Nucleosome assembly protein 1 -like 2 & NAP1L2 & 1.89 \\
\hline Glucosidase, alpha; neutral C & GANC & 1.86 \\
\hline Sarcoglycan, delta (35kDa dystrophin-associated glycoprotein) & SGCD & 1.81 \\
\hline High-mobility group nucleosome binding domain 1 & HMGN1 & 1.80 \\
\hline Solute carrier family 25 , member 29 & SLC25A29 & 1.77 \\
\hline Kruppel-like factor 4 (gut) & KLF4 & 1.76 \\
\hline Chromodomain helicase DNA binding protein 2 & CHD2 & 1.71 \\
\hline Acireductone dioxygenase 1 & ADI1 & 1.71 \\
\hline $\begin{array}{l}\text { Sema domain, immunoglobulin domain (lg), transmembrane } \\
\text { domain (TM) and short cytoplasmic domain, (semaphorin) 4B }\end{array}$ & SEMA4B & 1.70 \\
\hline RNA binding motif (RNP1, RRM) protein 3 & RBM3 & 1.70 \\
\hline ATP-binding cassette, sub-family A (ABC1), member 5 & ABCA5 & 1.70 \\
\hline Sulfatase 2 & SULF2 & 1.68 \\
\hline Guanine nucleotide binding protein ( $G$ protein), alpha z polypeptide & GNAZ & 1.68 \\
\hline DEAD (Asp-Glu-Ala-Asp) box polypeptide 27 & - & 1.66 \\
\hline UDP-Gal:betaGIcNAc beta 1,4- galactosyltransferase, polypeptide 1 & B4GALT1 & 1.63 \\
\hline Laminin, alpha 4 & LAMA4 & 1.63 \\
\hline Spermatogenesis associated 6 & SPATA6 & 1.62 \\
\hline Solute carrier family 2 (facilitated glucose transporter), member 3 & SLC2A3 & 1.60 \\
\hline Guanylate binding protein 1 , interferon-inducible, $67 \mathrm{kDa}$ & GBP1 & 1.57 \\
\hline Early B-cell factor 1 & EBF1 & 1.57 \\
\hline Polyhomeotic homolog 3 (Drosophila) & $\mathrm{PHC} 3$ & 1.56 \\
\hline Epoxide hydrolase 2, cytoplasmic & EPHX2 & 1.50 \\
\hline
\end{tabular}


Tabela 5 - Lista de genes sub-expressos no Grupo A (Tratado) em relação ao Grupo B (Não-Tratado)

\begin{tabular}{|c|c|c|}
\hline Genes sub-expressos & Identidade & Taxa \\
\hline WNT inhibitory factor 1 & WIF1 & -6.18 \\
\hline Myelin-associated oligodendrocyte basic protein & MOBP & -4.70 \\
\hline Calsequestrin 2 (cardiac muscle) & CASQ2 & -3.34 \\
\hline Glutamate receptor, ionotropic, AMPA 2 & GRIA2 & -3.19 \\
\hline Frizzled homolog 3 (Drosophila) & FZD3 & -2.99 \\
\hline Protein tyrosine phosphatase, receptor type, $R$ & PTPRR & -2.28 \\
\hline Chemokine (C-C motif) ligand 14 & CCL14 & -2.24 \\
\hline Integrin, beta 8 & ITGB8 & -2.23 \\
\hline Shroom family member 3 & SHROOM3 & -2.22 \\
\hline Monooxygenase, DBH-like 1 & MOXD1 & -2.18 \\
\hline Mitochondrial ribosomal protein S15 & MRPS15 & -2.17 \\
\hline Gap junction protein, alpha $5,40 \mathrm{kDa}$ & GJA5 & -2.14 \\
\hline Chloride channel 5 (nephrolithiasis 2, X-linked, Dent disease) & CLCN5 & -2.14 \\
\hline Chloride channel CLIC-like 1 & CLCC1 & -2.02 \\
\hline DNA-damage-inducible transcript 4-like & DDIT4L & -1.97 \\
\hline Src homology 2 domain containing adaptor protein B & $\mathrm{SHB}$ & -1.96 \\
\hline Integrin, alpha 8 & ITGA8 & -1.95 \\
\hline RUN and FYVE domain containing 2 & RUFY2 & -1.94 \\
\hline Solute carrier family 8 (sodium/calcium exchanger), member 1 & SLC8A1 & -1.92 \\
\hline RPA interacting protein & RPAIN & -1.92 \\
\hline F-box protein 28 & FBXO28 & -1.90 \\
\hline Attractin-like 1 & ATRNL1 & -1.90 \\
\hline Sulfatase 1 & SULF1 & -1.88 \\
\hline GULP, engulfment adaptor PTB domain containing 1 & GULP1 & -1.87 \\
\hline Multimerin 1 & MMRN1 & -1.86 \\
\hline Guanine nucleotide binding protein (G protein), alpha 14 & GNA14 & -1.85 \\
\hline Cyclin D1 & CCND1 & -1.84 \\
\hline $\begin{array}{l}\text { Inhibitor of DNA binding 3, dominant negative helix-loop-helix } \\
\text { protein }\end{array}$ & ID3 & -1.82 \\
\hline Protein phosphatase 4, regulatory subunit 2 & PPP4R2 & -1.77 \\
\hline Chromosome 17 open reading frame 81 & C17orf81 & -1.77 \\
\hline Integrin, alpha 2 (CD49B, alpha 2 subunit of VLA-2 receptor) & ITGA2 & -1.75 \\
\hline Myxovirus (influenza virus) resistance 2 (mouse) & MX2 & -1.70 \\
\hline $\begin{array}{l}\text { Solute carrier family } 35 \text { (UDP-glucuronic acid/UDP-N- } \\
\text { acetylgalactosamine dual transporter), member D1 }\end{array}$ & SLC35D1 & $\begin{array}{l}-1.64 \\
\text { continua }\end{array}$ \\
\hline
\end{tabular}


Tabela 5 - Lista de genes sub-expressos no Grupo A (Tratado) em relação ao Grupo B (Não-Tratado)

continuação

\begin{tabular}{|c|c|c|}
\hline Genes sub-expressos & Identidade & Taxa \\
\hline Rho family GTPase 2 & RND2 & -1.64 \\
\hline Potassium channel tetramerisation domain containing 10 & KCTD10 & -1.64 \\
\hline $\begin{array}{l}\text { Solute carrier family } 2 \text { (facilitated glucose/fructose transporter), } \\
\text { member } 5\end{array}$ & SLC2A5 & -1.62 \\
\hline Interferon-induced protein with tetratricopeptide repeats 3 & IFIT3 & -1.62 \\
\hline CDC-like kinase 4 & CLK4 & -1.61 \\
\hline Jub, ajuba homolog (Xenopus laevis) & JUB & -1.60 \\
\hline Metastasis associated 1 family, member 3 & MTA3 & -1.59 \\
\hline Genes sub-expressos & Identidade & Taxa \\
\hline SATB homeobox 1 & SATB1 & -1.58 \\
\hline FK506 binding protein $1 \mathrm{~A}, 12 \mathrm{kDa}$ & FKBP1A & -1.58 \\
\hline Phosphodiesterase 7B & PDE7B & -1.57 \\
\hline Chromosome 13 open reading frame 18 & C13orf18 & -1.57 \\
\hline Transmembrane protein 117 & TMEM117 & -1.56 \\
\hline Ribokinase & RBKS & -1.56 \\
\hline Polymerase (RNA) III (DNA directed) polypeptide G (32kD) & POLR3G & -1.56 \\
\hline KIAA1549 protein & KIAA1549 & -1.56 \\
\hline Kelch repeat and BTB (POZ) domain containing 8 & KBTBD8 & -1.56 \\
\hline UBX domain containing 6 & UBXD6 & -1.55 \\
\hline Leucine rich repeat and coiled-coil domain containing 1 & LRRCC1 & -1.55 \\
\hline Zinc finger and BTB domain containing 11 & ZBTB11 & -1.54 \\
\hline Ubiquitin protein ligase E3 component n-recognin 5 & UBR5 & -1.54 \\
\hline Ras association (RalGDS/AF-6) domain family 8 & RASSF8 & -1.53 \\
\hline Kelch-like 8 (Drosophila) & KLHL8 & -1.53 \\
\hline Glycoprotein M6B & GPM6B & -1.53 \\
\hline Sin3A-associated protein, $18 \mathrm{kDa}$ & SAP18 & -1.52 \\
\hline RAB22A, member RAS oncogene family & - & -1.52 \\
\hline Family with sequence similarity 119 , member $A$ & FAM119A & -1.52 \\
\hline Transmembrane and tetratricopeptide repeat containing 4 & TMTC4 & -1.51 \\
\hline Interferon induced with helicase $\mathrm{C}$ domain 1 & $\mathrm{IFIH} 1$ & -1.51 \\
\hline Cell death-inducing DFFA-like effector $b$ & CIDEB & -1.51 \\
\hline Ankylosis, progressive homolog (mouse) & ANKH & -1.51 \\
\hline Solute carrier family 17 (anion/sugar transporter), member 5 & SLC17A5 & -1.50 \\
\hline $\begin{array}{l}\text { Beta-1,3-N-acetylgalactosaminyltransferase } 1 \text { (globoside blood } \\
\text { group) }\end{array}$ & B3GALNT1 & -1.50 \\
\hline
\end{tabular}


Diante do grande número de genes diferencialmente expressos, selecionamos 4 genes super-expressos (indutor angiogênico rico em cisteína, 61; nucleossoma vinculado a grupo de alta mobilidade, domínio1, resposta a crescimento inicial 1 e Sulfatase 2) e 1 gene sub-expresso (WNT fator inibidor 1) (Gráficos 3 a 7) para confirmação por PCR em tempo real, embasados em dados da literatura.

Gráfico 3 - Expressão comparativa, por "microarray", do gene CYR61, nos dois grupos estudados

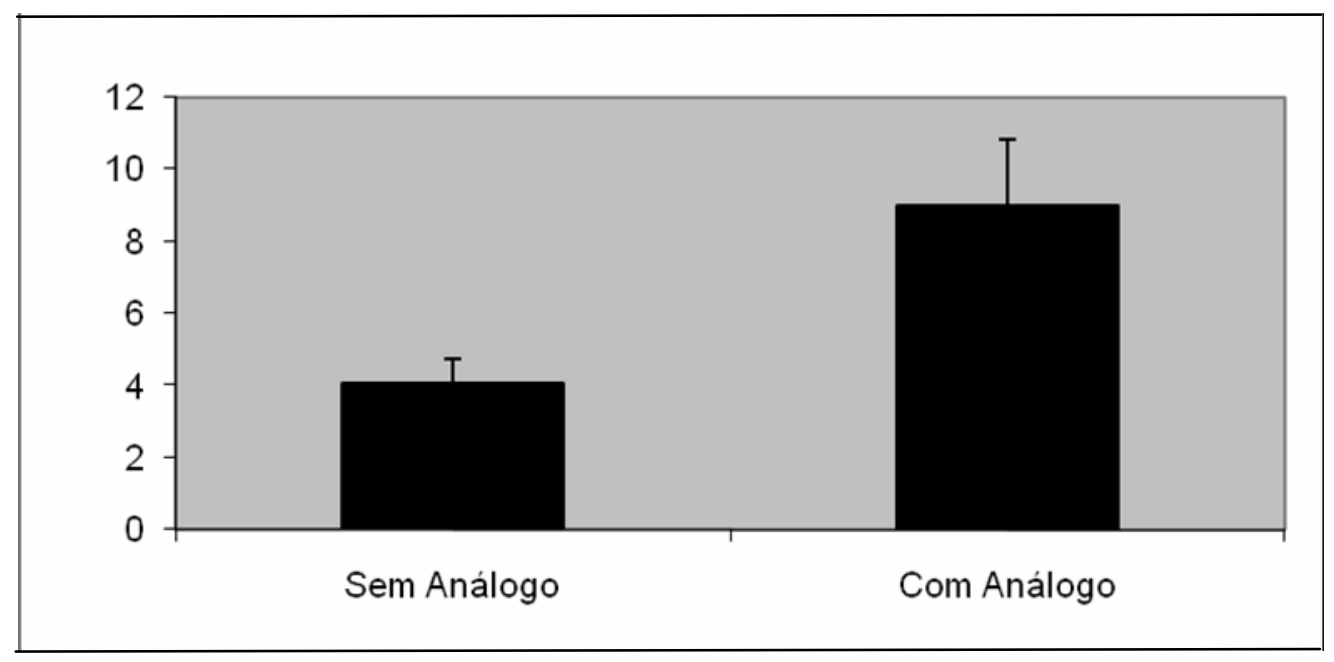

Gráfico 4 - Expressão comparativa, por "microarray", do gene HMGN1, nos dois grupos estudados

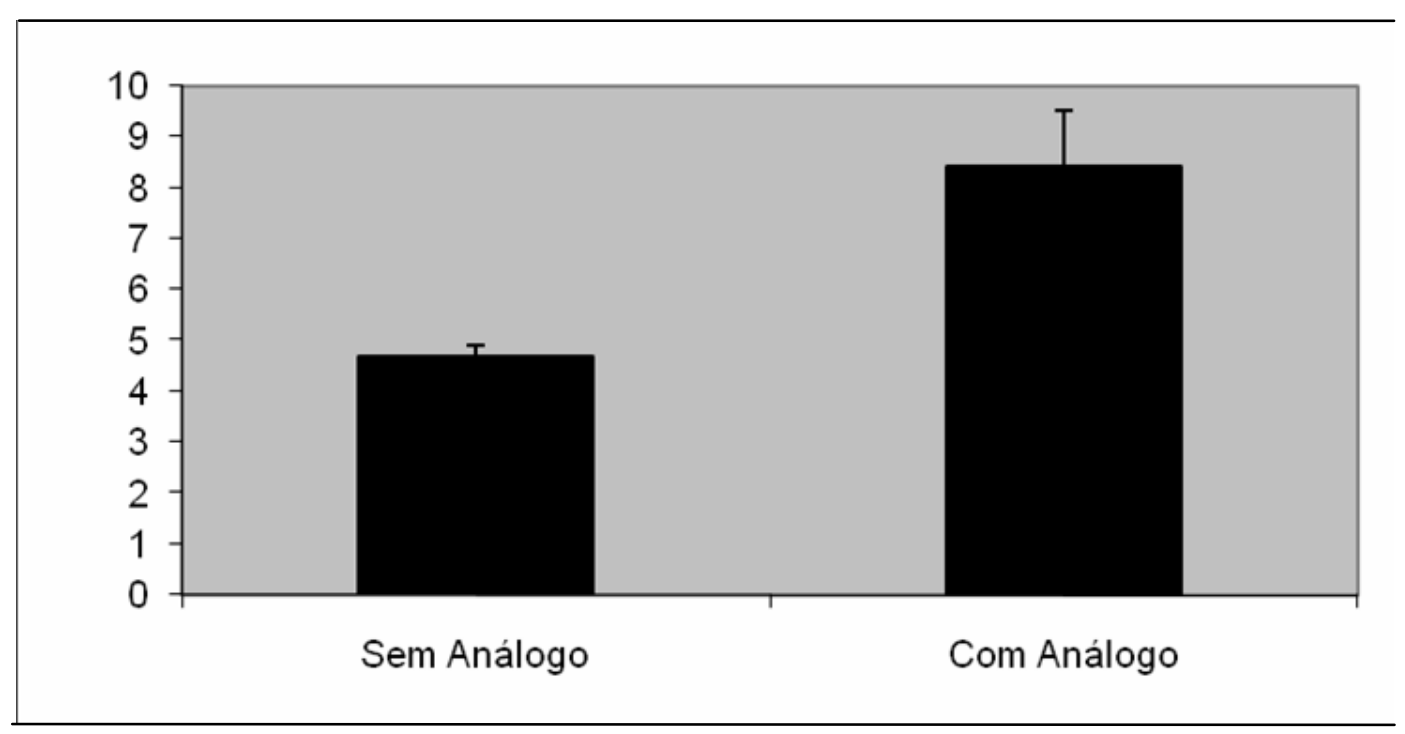


Gráfico 5 - Expressão comparativa, por "microarray", do gene EGR1, nos dois grupos estudados

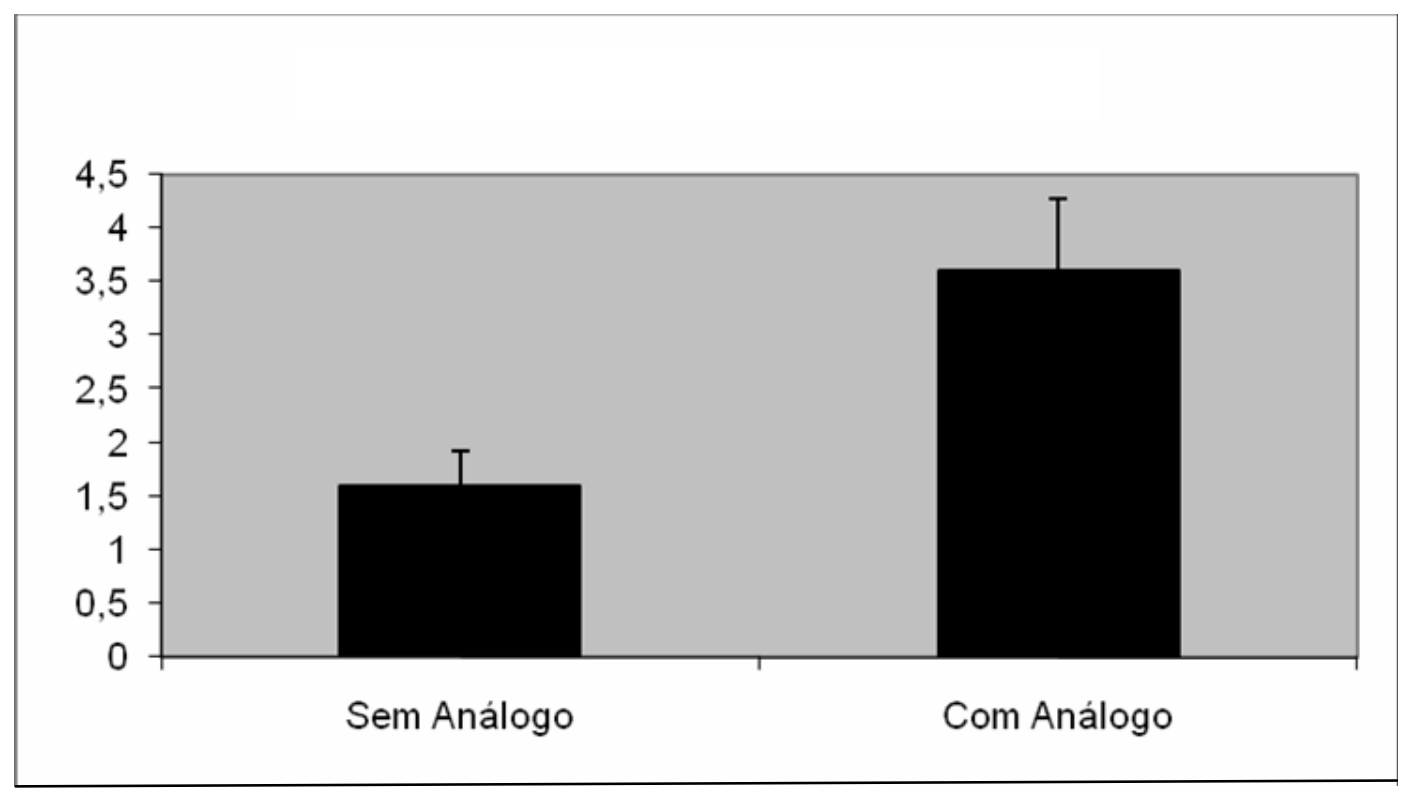

Gráfico 6 - Expressão comparativa, por "microarray", do gene SULF2, nos dois grupos estudados

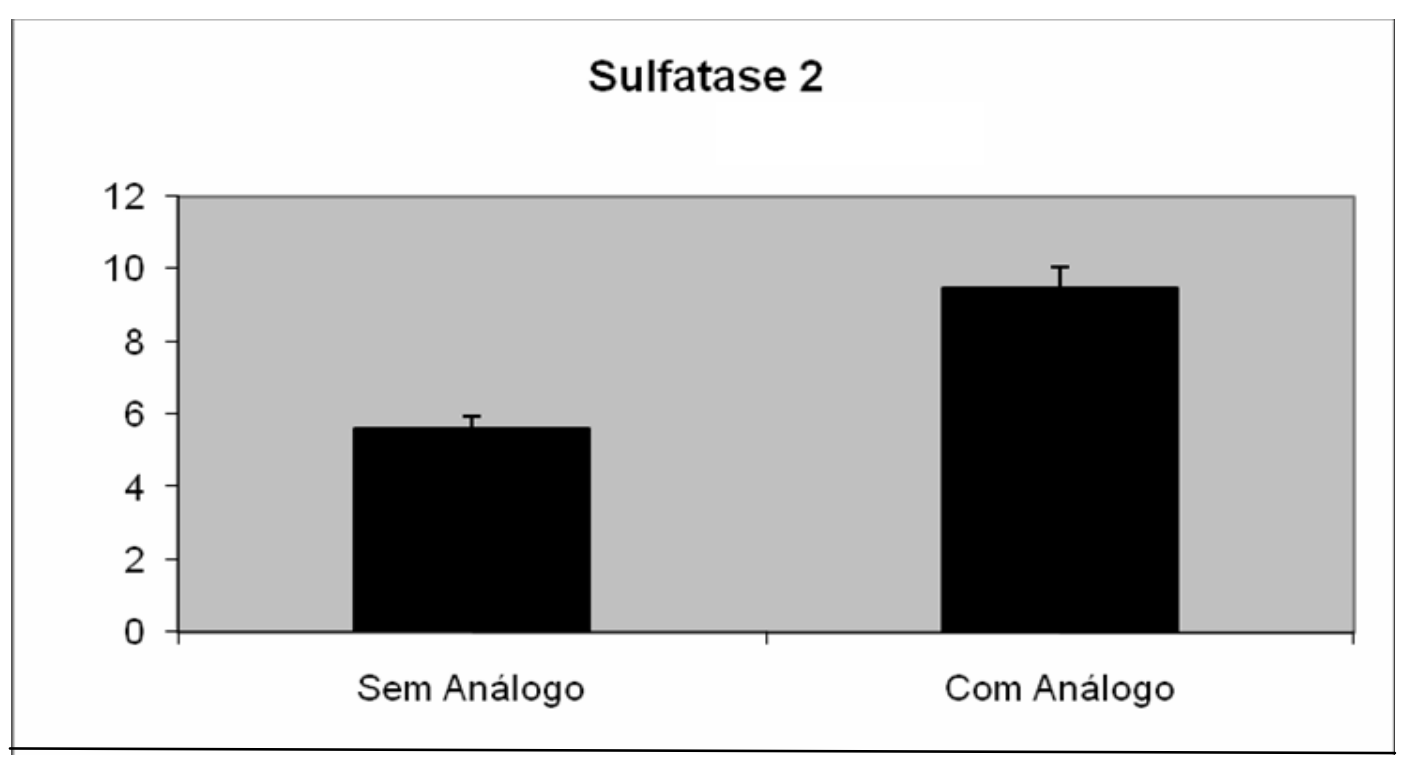


Gráfico 7: Expressão comparativa, por "microarray", do gene WIF1, nos dois grupos estudados

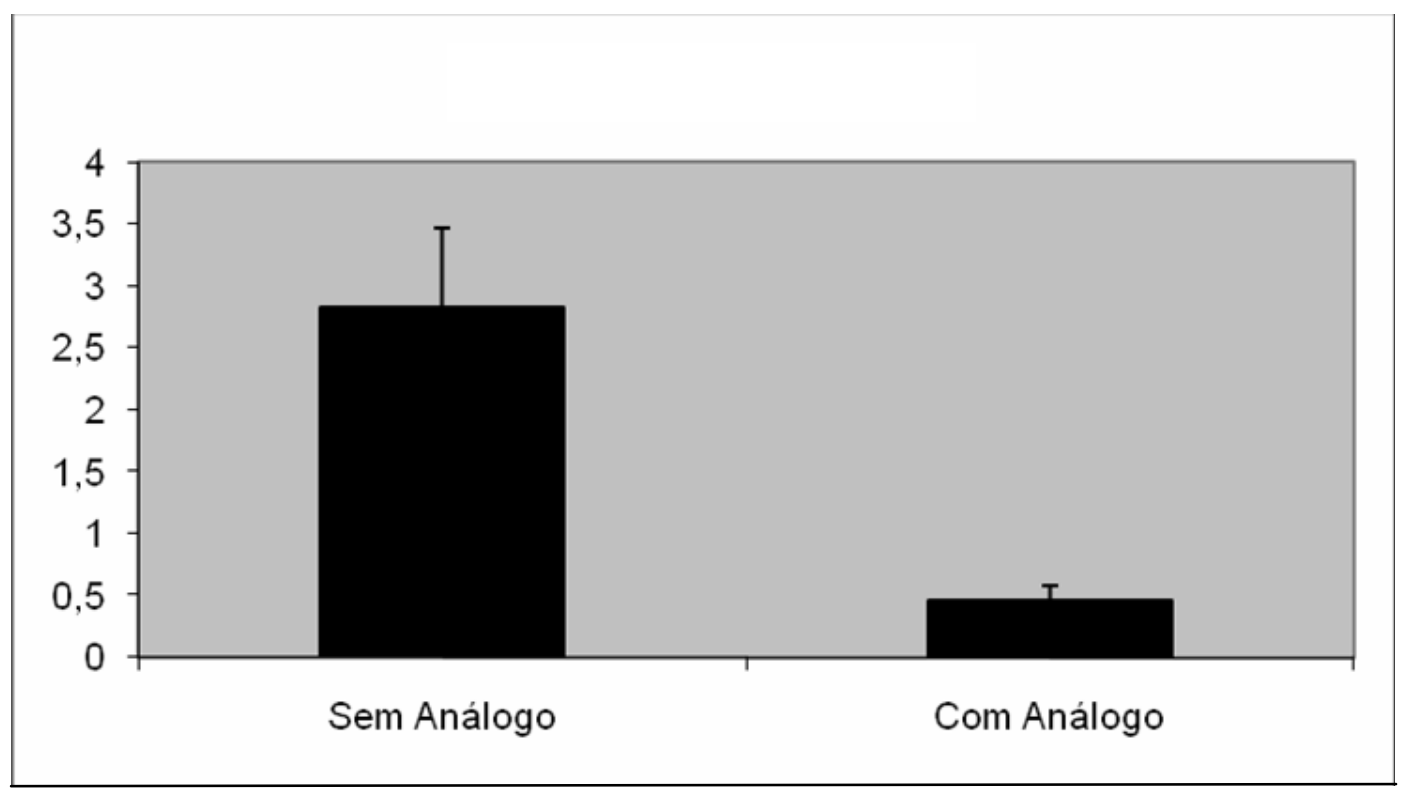

\subsection{Confirmação por PCR em tempo real}

Os resultados previamente obtidos pela técnica de "microarray" estão alinhados na Tabela 6.

Tabela 6 - Valores da taxa de expressão diferencial obtidos por "microarray" para os 5 genes de interesse

\begin{tabular}{cc}
\hline Gene & Taxa \\
\hline WIF1 & -6.18 \\
EGR1 & 2.26 \\
SULF2 & 1.68 \\
HMGN1 & 1.8 \\
CYR61 & 2.2 \\
\hline
\end{tabular}


Os resultados obtidos com a técnica de PCR em tempo real utilizando as mesmas amostras usadas no experimento de "microarray", estão discutidas nas Tabelas 7 e 8 e nos Gráficos 8 a 12.

Tabela 7 - Resultados do PCR em tempo real dos 5 genes avaliados, usando as mesmas amostras do "microarray"

\begin{tabular}{lllllccc}
\hline \multirow{2}{*}{ Gene } & Grupo & $\mathbf{N}$ & $\boldsymbol{\Delta} \mathbf{C T}$ & $\begin{array}{c}\text { Desvio } \\
\text { Padrão }\end{array}$ & $\begin{array}{c}\text { Erro } \\
\text { Padrão }\end{array}$ & $\begin{array}{c}\text { Fold } \\
\text { Change }\end{array}$ & $\mathbf{p}$ \\
\hline \multirow{2}{*}{ WIFI } & Grupo A & 5 & 6.72 & 1.45 & 0.65 & -5.58 & 0.02 \\
& Grupo B & 5 & 4.24 & 1.36 & 0.61 & & \\
\hline \multirow{2}{*}{ EGR1 } & Grupo A & 5 & 4.48 & 0.81 & 0.36 & 1.73 & 0.13 \\
& Grupo B & 5 & 5.27 & 0.66 & 0.30 & & \\
\hline \multirow{2}{*}{ SULF2 } & Grupo A & 5 & 2.50 & 0.19 & 0.09 & 1.32 & 0.03 \\
& Grupo B & 5 & 2.90 & 0.27 & 0.12 & & \\
\hline \multirow{2}{*}{ HMGN1 } & Grupo A & 5 & 11.87 & 0.71 & 0.32 & 1.04 & 0.92 \\
& Grupo B & 5 & 11.93 & 1.11 & 0.49 & & \\
\hline \multirow{2}{*}{ CYR61 } & Grupo A & 5 & 4.03 & 0.76 & 0.34 & 1.83 & 0.14 \\
& Grupo B & 5 & 4.91 & 0.92 & 0.41 & & \\
\hline
\end{tabular}

Obs: Valores de $\triangle C T$ utilizados para a comparação estatística entre os grupos, assim como o valor de fold change foram obtidos através da formula $2^{-(\Delta C T \text { com análogo- } \Delta C T \text { sem analogo })}$

Observa-se que, com exceção do HMGN1, a expressão relativa de todos os outros genes reproduz de maneira muito semelhante, a observada no resultado de "microarray". Entretanto, apesar de mostrarem tendência à significância (valor de $p \sim 0,1$, a diferença entre os grupos não é estatisticamente significativa para os genes EGR1 e CYR61 (Tabela 7). 
Tabela 8 - Resultados do PCR em tempo real dos 5 genes estudados, usando as mesmas amostras do "microarray" adicionadas a outras 5 amostras de cada grupo

\begin{tabular}{lccccccc}
\hline \multirow{2}{*}{ Gene } & Grupo & $\mathbf{N}$ & $\boldsymbol{\Delta} \mathbf{C T}$ & Padrão & Padrão & Change & $\mathbf{p}$ \\
\hline \multirow{2}{*}{ WIFI } & Grupo A & 10 & 7.73 & 2.50 & 0.79 & -3.01 & 0.20 \\
& Grupo B & 10 & 6.14 & 2.79 & 0.88 & & \\
\hline \multirow{2}{*}{ EGR1 } & Grupo A & 10 & 4.31 & 1.21 & 0.38 & 1.42 & 0.35 \\
& Grupo B & 10 & 4.82 & 1.12 & 0.35 & & \\
\hline \multirow{2}{*}{ SULF2 } & Grupo A & 10 & 2.41 & 0.47 & 0.15 & 1.37 & 0.02 \\
& Grupo B & 10 & 2.87 & 0.34 & 0.11 & & \\
\hline \multirow{2}{*}{ HMGN1 } & Grupo A & 10 & 12.11 & 0.78 & 0.25 & -1.24 & 0.60 \\
& Grupo B & 10 & 11.79 & 1.68 & 0.53 & & \\
\hline \multirow{2}{*}{ CYR61 } & Grupo A & 10 & 4.23 & 1.15 & 0.36 & 1.59 & 0.23 \\
& Grupo B & 10 & 4.90 & 1.24 & 0.39 & & \\
\hline
\end{tabular}

Obs: Valores de $\triangle C T$ utilizados para a comparação estatística entre os grupos, assim como o valor de fold change obtidos através da formula $2^{-(\Delta C P \text { com análogo- } \Delta C T \text { sem analogo) }}$

Nas Tabelas 7 e 8, observa-se que:

a. Os valores de Ct por amostra, tanto para o gene de interesse, como para o GAPDH, representam a média geométrica dos valores de $\mathrm{Ct}$ correspondente às três réplicas realizadas;

b. $\mathrm{O}$ valor de $\Delta \mathrm{Ct}$ corresponde ao valor de expressão do gene de interesse, já normalizado de acordo com o valor do gene de referência (GAPDH): $\left(\mathrm{Ct}_{\text {gene de interesse }}\right)$ - (Ct $\left.\mathrm{GPDH}\right)$;

c. O desvio padrão corresponde à soma dos desvios-padrão das triplicatas e pode ser utilizado para a identificação de anomalias, ou seja, de 
amostras que apresentaram variação significativa entre os experimentos, e que devem portanto, ser eliminadas;

d. O valor de desvio padrão superior a 0,3 é considerado indicativo da presença de anomalias. Como pode-se observar, os valores estão dentro da variação esperada, o que significa que as triplicatas são consistentes e que os valores de Ct são reais;

e. Como o valor de Ct é inversamente proporcional à quantidade de RNA e ao nível de expressão, para a elaboração dos gráficos foi utilizado o valor correspondente a $1 / \Delta \mathrm{Ct}$.

Na replicação dos resultados, incluindo 05 novas amostras, podemos notar que, apesar das tendências serem mantidas, apenas o gene SULF2 se confirma como estatisticamente mais expresso no grupo com análogo em relação ao sem análogo (Tabela 8).

Com 10 amostras por grupo, o estudo apresenta poder estatístico de $80 \%$ para detectar diferenças mínimas de 0,4 nos valores de $\Delta \mathrm{CT}$, ou seja, o estudo tem poder para detectar diferenças entre os grupos até inferiores às observadas na Tabela 8. A diferença não significativa deve-se principalmente à grande variabilidade entre as amostras de um mesmo grupo, o que pode ser verificado pelos valores de desvio-padrão. 
Gráfico 8 - Expressão média, por PCR em tempo real, do gene WIF1 nos grupos com e sem análogo

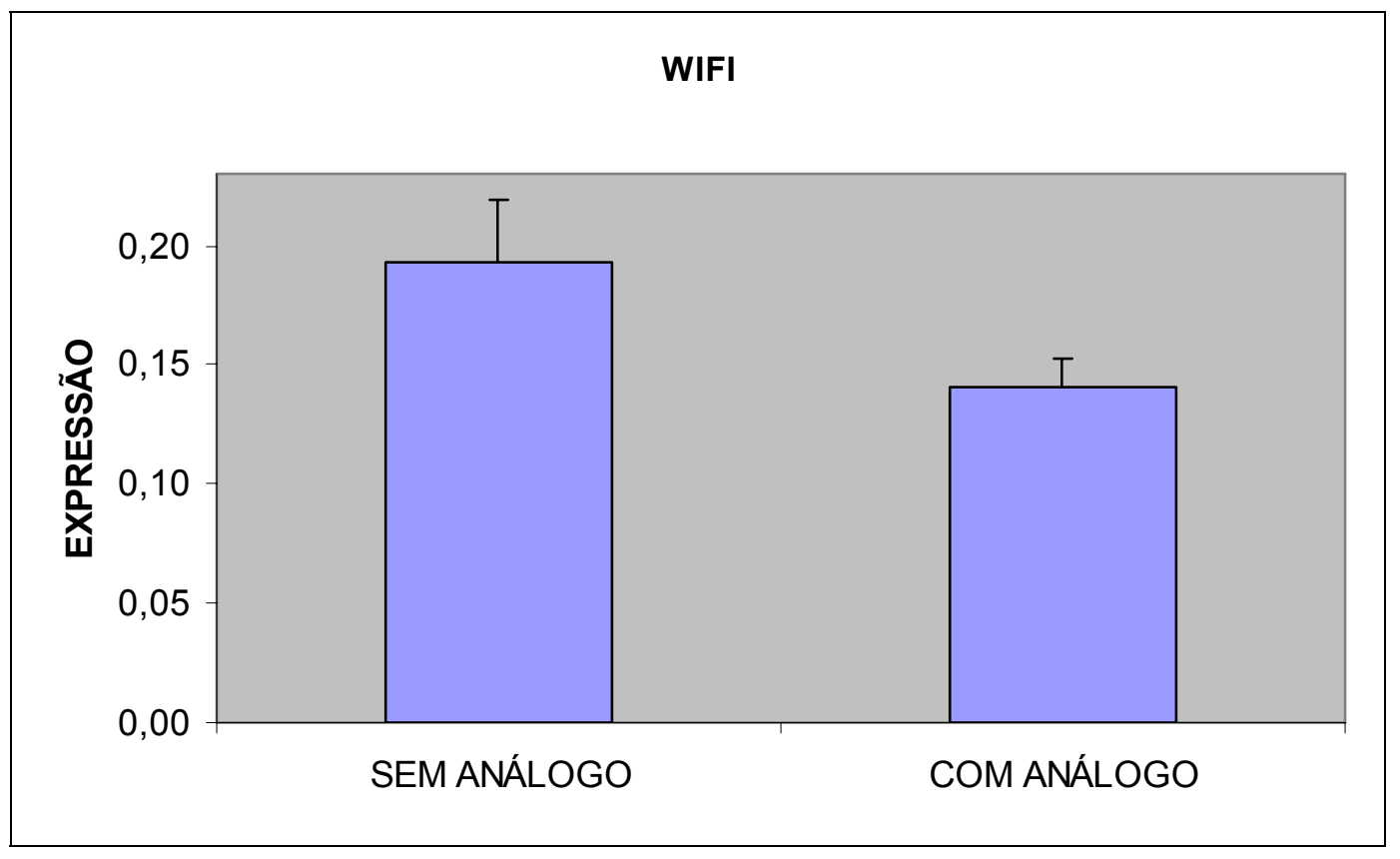

Gráfico 9 - Expressão média, por PCR em tempo real, do gene EGR 1 nos grupos com e sem análogo

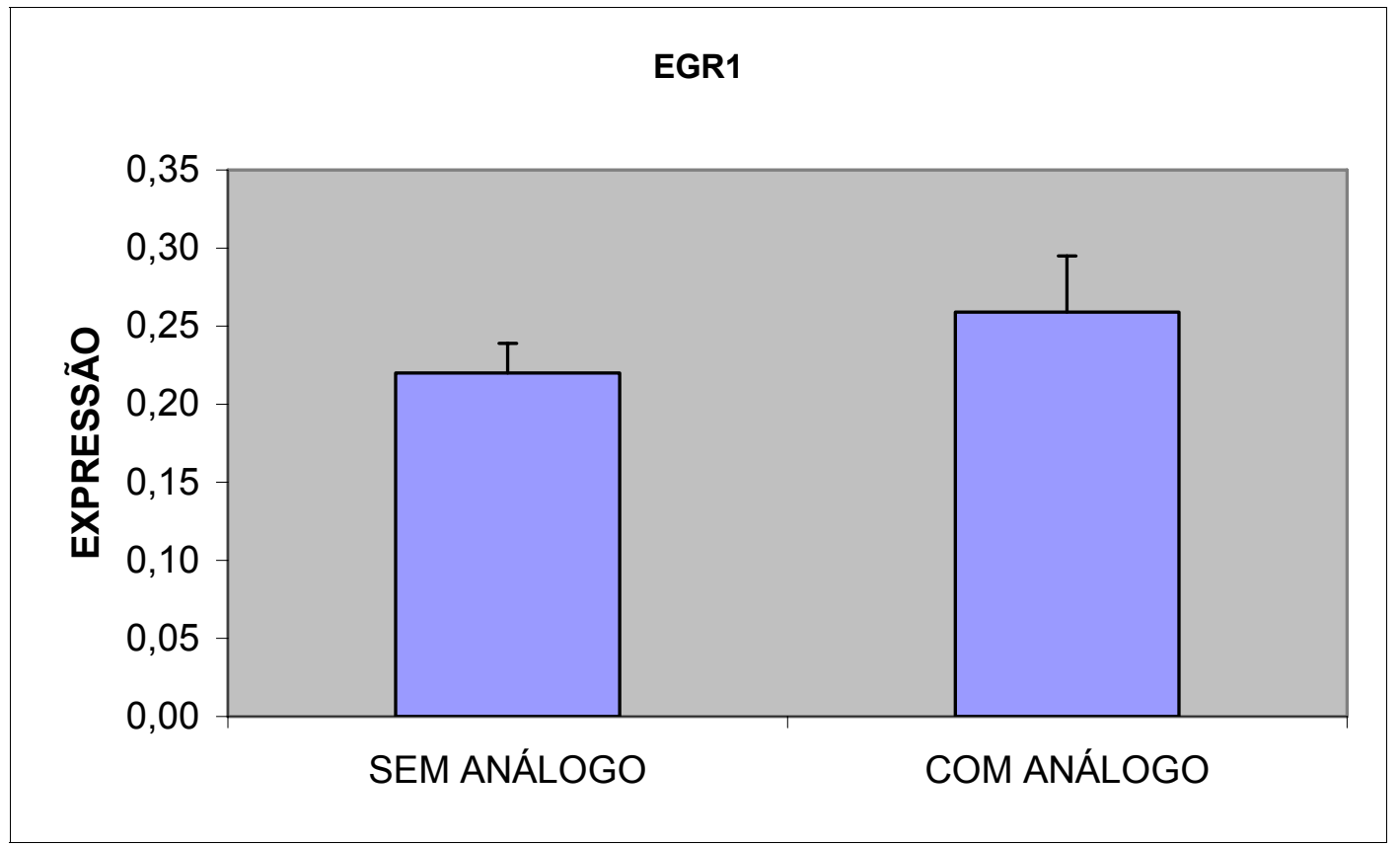


Gráfico 10 - Expressão média, por PCR em tempo real, do gene SULF 2 nos grupos com e sem análogo

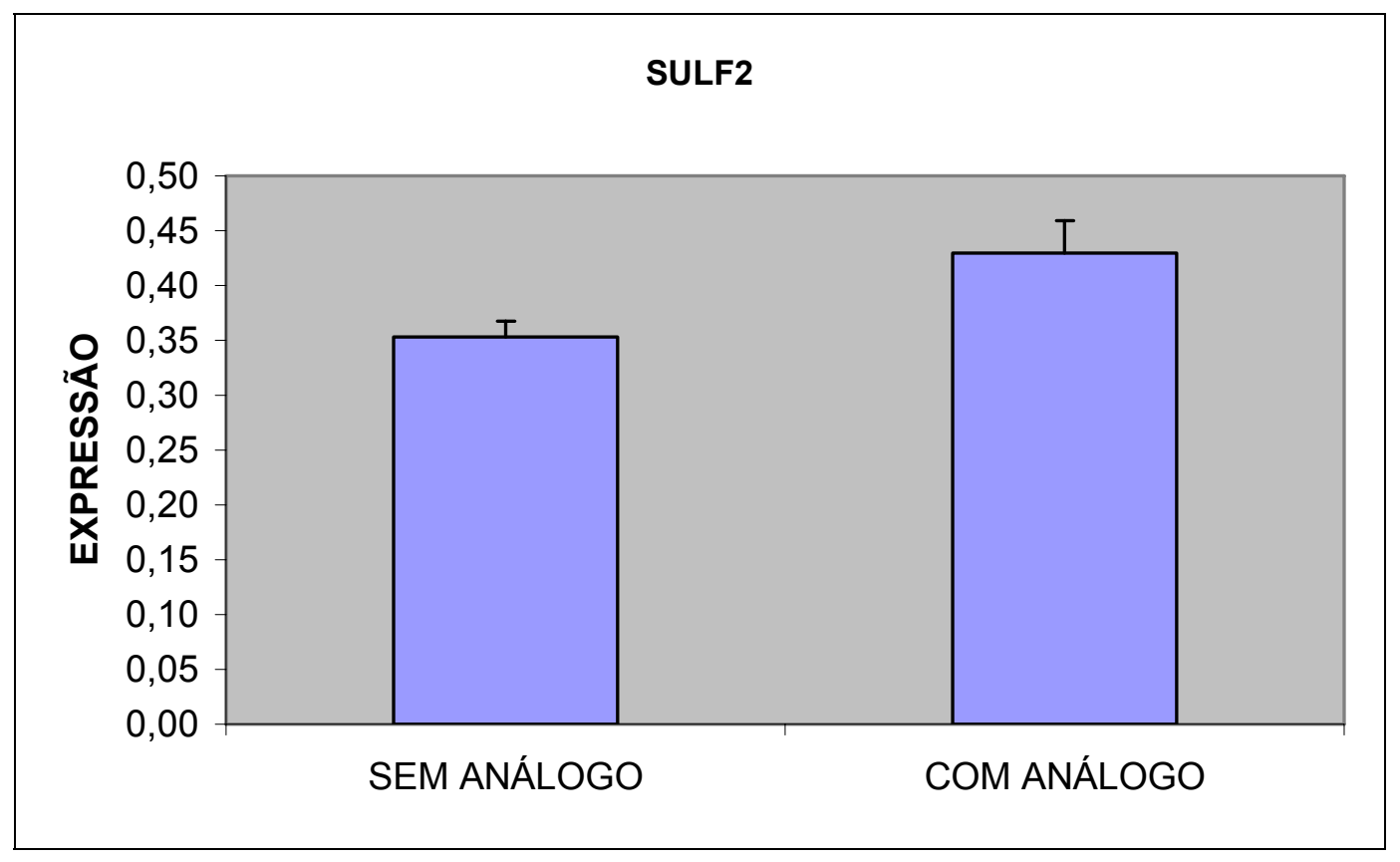

Gráfico 11 - Expressão média, por PCR em tempo real, do gene HMGN 1 nos grupos com e sem análogo

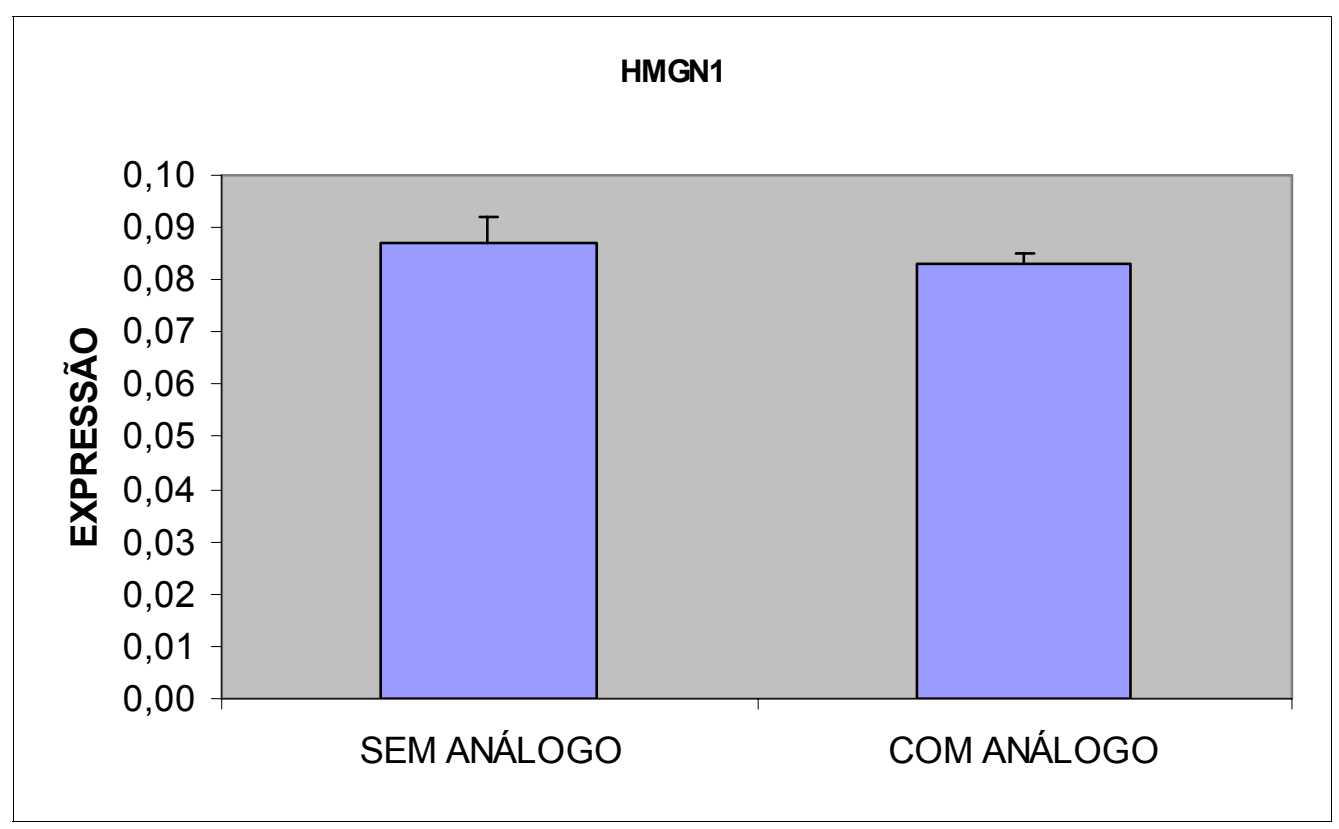


Gráfico 12 - Expressão média, por PCR em tempo real, do gene CYR 61 nos grupos com e sem análogo

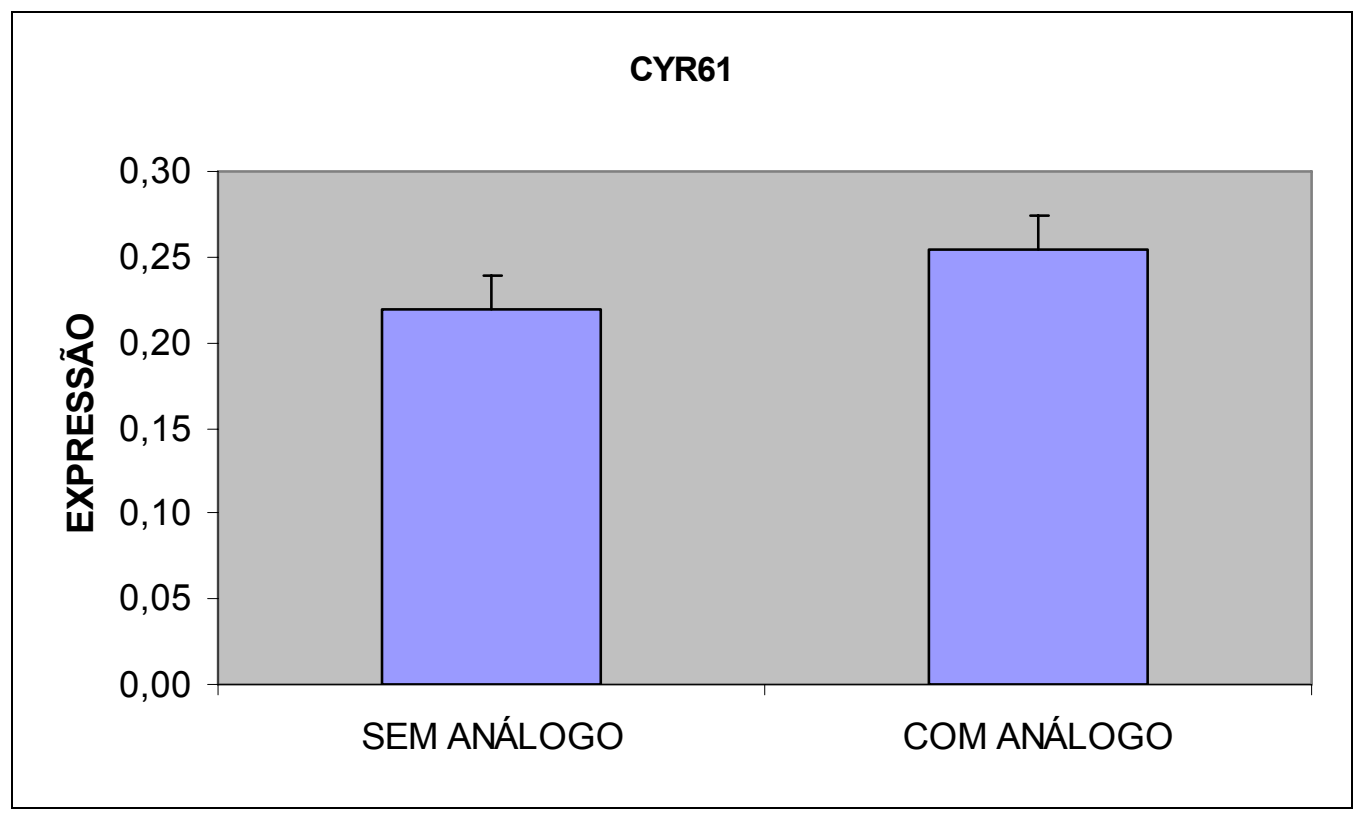


5 DISCUSSÃO 
O leiomioma, tumor benigno da musculatura lisa uterina, monoclonal, que acomete o útero em variadas localizações, causa enorme impacto na qualidade de vida das mulheres, devido a sua alta prevalência, sintomatologia e interferência na fertilidade. Esses fatos, aliados à indicação de grande número de procedimentos cirúrgicos (histerectomias e miomectomias), geram altos custos ambulatoriais e hospitalares. Constitui, portanto, relevante problema de saúde pública (Wu et al., 2007).

O desenvolvimento de pesquisas sobre a etiopatogenia do leiomioma uterino tem possibilitado avanços na terapêutica, até então restrita à limitada ação de medicamentos e procedimentos cirúrgicos invasivos e, com freqüência, radicais.

A partir da década de 80 , surgiram os primeiros trabalhos sobre a ação do GnRHa nesse tumor, embasados em observações clínicas da sua dependência em relação aos hormônios esteróides. A partir de então, essa medicação tornou-se importante instrumento terapêutico, principalmente em pacientes com desejo reprodutivo. Esse contexto, associado à demanda cada vez maior do tratamento conservador, impulsionada pelo novo posicionamento da mulher na sociedade e adiamento da primeira gravidez, motivou o estudo e a aplicação dessa nova terapêutica em nosso meio. Assim, o uso do GnRHa em pacientes com leiomioma uterino foi motivo da tese de doutorado apresentada à Disciplina de Obstetrícia e Ginecologia da Faculdade de Medicina da Universidade de São Paulo, publicada em 2003. Concluiu-se que a ação desse medicamento não se fazia apenas pelo bloqueio do eixo hipotálamo-hipofisário, mas também diretamente no tecido 
tumoral, causando diminuição da concentração dos receptores de estrogênio e aumento da concentração dos receptores de progesterona nos casos com maior resposta (maior redução volumétrica) (Bozzini et al., 2003).

No entanto, o uso de GnRHa apresenta limitações relacionadas sobretudo aos seus efeitos colaterais (sinais e sintomas de hipoestrogenismo e perda de massa óssea) (Lethaby et al., 2001).

Nas duas últimas décadas, o desenvolvimento de novas técnicas de biologia molecular, associado aos conhecimentos epidemiológicos, clínicos e citogenéticos, incrementou o estudo e o conhecimento de fatores genéticos implicados na gênese do leiomioma. A técnica de "microarray" otimiza a construção do conhecimento genético, facilitando a análise de milhares de genes simultaneamente. A revisão dos estudos que aplicam essa técnica denota um amadurecimento não apenas da utilização da técnica, mas também possibilita a análise crítica dos seus resultados. Já em 2003, Catherino et al. (2004a) criticaram a validade dos inúmeros genes descritos como diferencialmente expressos, em geral, estudados comparando o tecido do leiomioma e o do miométrio adjacente. Esse mesmo grupo publicou, também, modelo para a confirmação dos dados de "microarray", utilizando técnicas já consagradas, como RT-PCR, PCR em tempo real, Westhern Blot, imunoistoquímica, entre outras. Desde então, todos os trabalhos têm utilizado o "microarray" como um método de triagem, seguido sempre da confirmação das alterações descritas por técnicas quantitativas (Catherino et al., 2003b). 
Outra constatação é o grande número de genes diferencialmente expressos entre o leiomioma e o miométrio adjacente, com diferentes funções conhecidas, além da grande diversidade de resultados dos diferentes autores. Justifica-se esta heterogeneidade de resultados por se utilizar diferentes amostras, coleta e processamento de materiais; metodologias com diferentes plataformas para a leitura do "microarray", além de dados amostrais variáveis como idade, raça, fase do ciclo menstrual, posição e tamanho do tumor analisado (Wang et al., 2003; Wei et al., 2005, 2006)

Em virtude desses aspectos, procuramos pesquisar as alterações gênicas do leiomioma uterino associadas ao uso de GnRHa. Essas alterações podem trazer informações importantes não apenas relacionadas à sua etiopatogenia, mas esclarecer também o mecanismo de ação do medicamento, possibilitando, assim, terapias mais específicas, com menos efeitos colaterais e, portanto, mais seguras.

Para tanto, em nosso estudo, houve restrição na seleção das pacientes pela adoção de algumas variáveis (raça, paridade, fase secretória do ciclo menstrual, nódulos acima de $3,0 \mathrm{~cm}$, intramurais, terapia hormonal prévia), que julgamos importantes para determinar discrepâncias na expressão gênica dos leiomiomas uterinos. Limitar a análise à raça negra é justificável pelos dados da literatura, devido à diferença de expressão gênica em afro-americanas em relação às caucasianas (Wei, et al., 2005; Pan, et al., 2007). 
Da mesma forma, a fase do ciclo menstrual constitui importante elemento metodológico que pode influenciar a expressão gênica, como foi referido por Wang, em 2003. Sendo assim, procuramos obter as amostras após o $14^{\circ}$ dia do ciclo menstrual, ou seja, na fase secretória.

A nuliparidade foi outro critério adotado para uniformizarmos a seleção das pacientes analisadas (Schwartz, 2001; Parker, 2007). Tal fato não foi descrito em nenhum outro trabalho, o que provavelmente pode contribuir para um viés nos resultados.

A utilização de diversas plataformas de "microarray", algumas consideradas "caseiras", consiste em outro fator que aumenta a heterogenicidade dos resultados. Portanto, o uso da plataforma Affimetrix busca, também, trazer maior uniformidade, uma vez que a maioria dos trabalhos a emprega em suas análises.

A análise descritiva de nossos resultados mostrou homogeneidade quanto à idade $(p=0,955)$, IMC $\quad(p=0,754)$, diâmetro do maior nódulo $(p=0,173)$ e número de nódulos retirados $(p=0,912)$.

Nosso trabalho, usando a técnica de "microarray", procura comparar a ação do GnRHa na expressão gênica do leiomioma uterino em mulheres tratadas e não tratadas. Ao contrário, a maioria dos estudos da literatura avaliou o perfil de expressão gênica associado ao uso de GnRHa comparando o leiomioma ao miométrio adjacente.

Do total de 47.000 seqüências da plataforma utilizada, representando em torno de 38.500 genes humanos já caracterizados, houve a expressão diferencial de 174 genes, dos quais 70 estavam super-expressos (33 genes 
com função conhecida) e 104 sub-expressos (65 genes com função conhecida) no grupo tratado comparativamente ao grupo não tratado.

O número de genes diferencialmente expressos é similar àquele encontrado na literatura em estudos que comparam o leiomioma e o miométrio adjacente. No entanto, os genes por nós caracterizados (Tabelas 4 e 5) são bastante distintos, quando comparados aos resultados de outros autores. Apesar de serem genes distintos, por falta de outros trabalhos na literatura, utilizaremos como parâmetros os genes alvos já descritos.

O único gene em comum nas Tabelas 2, 4 e 5 é o indutor angiogênico rico em cisteína 61 (CYR 61) já salientado por outros autores (Tsibris et al., 2002; Ahn et al., 2003; Quade et al., 2004; Hoffman et al., 2004; Arslan et al., 2005; Lee et al., 2005). Atua como um degradador de IGF 2 e está subexpresso no leiomioma em relação ao miométrio (Weston et al., 2003). Portanto, sua redução causa aumento de IGF 2 (aumentada no leiomioma) e conseqüente incremento da proliferação celular e redução da apoptose, colaborando, assim, para o crescimento tumoral (Arslan et al., 2005). Nosso resultado está de acordo com tais achados, pois a super-expressão de CYR 61, após tratamento com GnRHa, causa queda de IGF 2, redução da proliferação celular e apoptose, justificando, assim, a diminuição volumétrica observada. Outra ação conhecida desse gene no leiomioma é antiangiogênica. Ele integra a ação de células endoteliais, fibroblastos e macrófagos na regulação do processo de angiogênese, inflamação e remodelação da matriz extracelular na cicatrização. Na sua falta, justifica-se 
a formação de fibrose e a redução da densidade vascular nos leiomiomas (Chen et al., 2001; Weston et al., 2003).

O grupo de proteínas de alta mobilidade (HMG) é responsável pela correta conformação tridimensional do complexo proteína-DNA e, portanto, apresenta papel relevante nos processos celulares, como a transcrição de DNA. Dentro desse grupo, nosso estudo detectou aumento da expressão do gene HMGN1 no grupo tratado com GnRHa. Esse gene inibe a produção local de estrogênio impulsionado pela ativação do gene FOS, sub-expresso no leiomioma em relação ao miométrio (Arslan et al., 2005). Portanto, o resultado aferido corrobora os dados da literatura, justificando o aumento de HMGN1 com o uso de análogo, o que levaria à queda de estrogênio local e à redução do tumor. No entanto, não encontramos o aumento esperado na expressão do gene FOS.

O incremento da expressão gênica do gene sulfatase 2 também está em concordância com a literatura. O Sulfatase 2 está reduzido no leiomioma em relação ao miométrio; portanto, durante a ação do $\mathrm{GnRHa}$, espera-se um acréscimo desse gene, responsável pela redução do crescimento tumoral em células de mieloma humano. Quanto às sulfatases, esse gene modula as interações de proteoglicanas no microambiente extracelular (MorimotoTomita et al., 2002).

O gene EGR1 que codifica uma proteína nuclear, tem a função de regular a transcrição, atuando na diferenciação celular e na inibição tumoral. Geralmente, seus níveis estão reduzidos no leiomioma. Nosso estudo demonstrou aumento desse gene no grupo tratado com GnRHa, o que 
justifica a diminuição do tumor. Em contrapartida, Shozu et al. (2004) relataram aumento de EGR1 apenas no miométrio após tratamento com GnRHa o que justificaria a regressão maior da espessura do miométrio com essa terapia.

Finalmente, a redução de WIF1 no grupo tratado com GnRHa constitui um resultado ainda não descrito na literatura. Esse gene tem papel significante na carcinogênese, e pode tornar-se importante marcador tumoral de diagnóstico e prognóstico. Codifica uma proteína que se liga ao WNT e inibe sua atividade. Em leiomiomas, há a descrição de aumento da expressão do WNT5b e do "secreted frizzled related protein" (sFRP)1, dois membros da família de genes WNT, na fase secretória do ciclo menstrual (Mangioni et al., 2005). Dessa forma, é contraditório com a resposta observada no leiomioma uterino, na presença de GnRHa, a redução de um fator que inibe o crescimento tumoral.

Quanto ao resultado do PCR em tempo real, há concordância com a literatura pela concordância com o resultado do "microarray" em 4 de 5 genes analisados (80\%), além da similaridade das taxas de expressão diferencial encontradas. No entanto, a inversão da expressão do HMGN1 se contrapõe aos dados da literatura.

A ausência de significância estatística deve-se, provavelmente, à variabilidade das amostras, artefato intrínseco ao estudo que não se pode controlar antes da coleta do material biológico.

Os dados obtidos neste estudo representam apenas uma pequena parte das informações contidas nos resultados do "microarray". Cremos que, 
futuramente, os genes por nós detectados possibilitem traçar novas estratégias na investigação de mulheres com risco de desenvolver leiomioma ou, ainda, naquelas com diagnóstico já estabelecido. 
6 CONCLUSÕES 
O número de genes sub-expressos $(n=65)$ no leiomioma foi aproximadamente o dobro dos genes super-expressos $(n=33)$ em mulheres tratadas com análogo de $\mathrm{GnRH}$ quando comparadas às não tratadas.

Dos 5 genes selecionados pela técnica de "microarray", 80\% foram confirmados por meio de PCR em tempo real; os genes CYR 61, EGR1 e SULF2 estavam super-expressos e o gene WIF1 sub-expresso em mulheres que fizeram uso de análogo de GnRH em relação às não tratadas; e a super-expressão do gene HMGN1, aferida por "microarray", não foi confirmada por PCR em tempo real. 
7 ANEXOS 


\section{ANEXO 1}

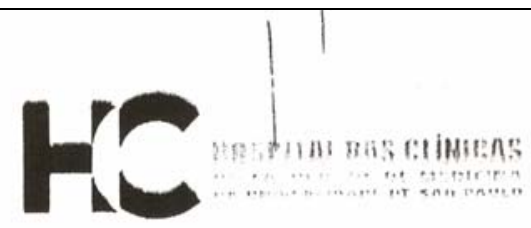

\section{APROVACÄO}

A Comissão de Ética para Análise de Projetos de Pesquisa - CAPPesq da Diretoria Clínica do Hospital das Clínicas e da Faculdade de Medicina da Universidade de São Paulo, em sessão de 27.07.06, APROVOU o Protocolo de Pesquisa $n^{\circ}$ 199/06, intitulado: "Estudo da expressão gênica do leiomioma uterino êtr mulheres submetidas à miomectomia" apresentado pelo Departamento de Obstetrícia e Ginecologia, inclusive o Termo de Consentimento Livre e Esclarecido.

$$
\text { Cabe do pesquisador elaborar e apresentar d̀ }
$$
CAPPesq, os relatórios parciais e final sobre a pesquisa (Resolução do Conselho Nacional de Saúde $n^{\circ} 196$, de 10.10.1996, inciso tX. 2, letra "c")

Pesquisador(a) Respohsável: Dr(a): Nilo Bozzini

Pesquisador(a) Executante: Dr(a): Rodrigo Borsari

CAPPesq, 27 de Julho dé 2006.

$$
\text { buld Callo }
$$

PROF. DR. EUCLIDES AYRES DE CASTILHO Presidente da Comissão de Ética para Análise de Projetos de Pesquisa

\footnotetext{
Comissto de Ética para Anólise de Projetós de Pesquisa do HCF MUSP e da FMUSP

biretoria Clinica do Hospital das Clinicas da Foculdade de Medieina da Universidade de Sto Paulo

Rua Ovídio Pirés de Cathpos. 225, $5^{\circ}$ andar - CEP 05403010 - 5870 Poulo - $5 P$

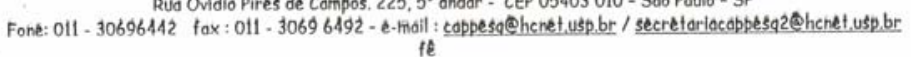




\title{
ANEXO 2
}

\author{
HOSPITAL DAS CLÍNICAS DA \\ FACULDADE DE MEDICINA DA UNIVERSIDADE DE SÃO PAULO \\ DIRETORIA CLÍNICA \\ COMISSÃO DE ÉTICA PARA ANÁLISE DE PROJETOS DE PESQUISA - \\ CAPPesq
}

TERMO DE CONSENTIMENTO LIVRE E ESCLARECIDO

I - DADOS DE IDENTIFICAÇÃO DO SUJEITO DA PESQUISA OU RESPONSÁVEL LEGAL

1. NOME DO PACIENTE

DOCUMENTO DE IDENTIDADE No : SEXO : .M F DATA NASCIMENTO: .......................
ENDEREÇO $\mathrm{N}^{\mathrm{o}}$ APTO:
BAIRRO: CIDADE

CEP TELEFONE: DDD ...)

2.RESPONSÁVEL LEGAL

NATUREZA (grau de parentesco, tutor, curador etc.)

DOCUMENTO DE IDENTIDADE : SEXO: $M \quad F$ DATA NASCIMENTO.: ....................

ENDEREÇO: $\mathrm{N}^{\mathrm{O}}$ APTO:

BAIRRO: CIDADE:

CEP: TELEFONE DDD (..... ..)...

II - DADOS SOBRE A PESQUISA CIENTÍFICA

1. TÍTULO DO PROTOCOLO DE PESQUISA : ESTUDO DA EXPRESSÃO GÊNICA DO LEIOMIOMA UTERINO EM MULHERES SUBMETIDAS À MIOMECTOMIA 
2. PESQUISADOR: Nilo Bozzini

CARGO/FUNÇÃO: Médico Assistente INSCRIÇÃO CONSELHO REGIONAL No: 19241

UNIDADE DO HCFMUSP: Disciplina de Ginecologia do Departamento de Obstetrícia/Ginecologia FMUSP.

3. AVALIAÇÃO DO RISCO DA PESQUISA:

SEM RISCO RISCO MÍNIMO RISCO MÉDIO X

RISCO BAIXO RISCO MAIOR

(probabilidade de que o indivíduo sofra algum dano como consequência imediata ou tardia do estudo)

4. DURAÇÃO DA PESQUISA: 24 meses

\section{III - REGISTRO DAS EXPLICAÇÕES DO PESQUISADOR AO PACIENTE OU SEU REPRESENTANTE LEGAL SOBRE A PESQUISA CONSIGNANDO:}

1. Justificativa e os objetivos da pesquisa - A Sra. está sendo convidada a colaborar com uma pesquisa para tentar ajudar a descobrir o motivo do surgimento do mioma do útero. Essa pesquisa é importante porque o mioma do útero causa hemorragia, dor e dificuldade de gravidez em mulheres jovens, geralmente dos 20 aos 50 anos. Até pouco tempo atrás, o tratamento mais utilizado era a retirada do útero, e hoje com novos tipos de cirurgias e novas medicações conseguimos manter o útero de algumas pacientes que tem mioma uterino, mas ainda não tiveram filhos ou querem engravidar novamente. Não existe ainda nenhuma medicação que cura o mioma do útero ou faça ele diminuir e não voltar a crescer. Hoje a medicação utilizada é para controlar as dores ou os sangramentos aumentados. $\mathrm{O}$ análogo do GnRH, uma injeção aplicada abaixo da pele da barriga em algumas pacientes, geralmente deixa a mulher sem menstruar e diminui o tamanho do mioma mas não pode ser usada por mais de 6 meses por risco de perda de osso, podendo causar, fraturas ósseas graves. Quando parada essa medicação o mioma volta a crescer e os sintomas como dor e sangramento voltam a incomodar. Por isso, se através dessa pesquisa conseguirmos colaborar com outros estudos para saber o que causa o aparecimento e o crescimento do mioma do útero, poderemos com esse novo conhecimento criar tratamentos mais eficientes contra o mioma do útero. Para isso iremos dividir as pacientes dessa pesquisa em dois grupos sendo que um grupo será tratado com a medicação (Análogo de $\mathrm{GnRH}$ ) para parar o sangramento e diminuir o tamanho do tumor durante 3 meses e depois fará cirurgia e o outro grupo será submetida de imediato a cirurgia. 
2. Procedimentos que serão utilizados e propósitos, incluindo a identificação dos procedimentos que são experimentais - Para realização dessa pesquisa a Sra. deverá colaborar autorizando a coleta de 1 seringa de $10 \mathrm{ml}$ (média) de sangue de uma veia do braço como sempre é realizado para coleta de exames laboratoriais, além de realizar outros exames pré-operatórios normais para qualquer cirurgia como por exemplo para saber se o seu hemograma, que é um exame para verificar se o seu sangue esta normal ou com anemia. Esse sangue será utilizado para analise dos genes da Sra. e se for necessário comparar com genes de outras mulheres com miomas ou ainda com mulheres que não têm miomas. A Sra. deverá autorizar também o uso de um pedaço do mioma retirado durante a cirurgia (miomectomia) e que normalmente vai para analise microscópica, para a realização da análise dos genes desse tumor. Os genes desse mioma serão comparados com os genes de um pedaço do músculo uterino normal (miométro) que será retirado somente com a sua autorização durante a cirurgia, enquanto a Sra. estiver anestesiada sem risco adicional ou prejuízo para o resultado final da usa cirurgia.

Se a Sra. fizer parte do grupo de mulheres que vai precisar usar Análogo de $\mathrm{GnRH}$, injeção realizada na pele da barriga abaixo do umbigo, antes da cirurgia, receberá essa injeção a cada trinta dias com acompanhamento médico mensal. O objetivo dessas injeções é causar diminuição do mioma, parada do sangramento menstrual e melhora de anemia para posterior cirurgia com maior segurança e menor possibilidade de receber transfusão de sangue. Atenção! As pacientes que necessitarão tomar essas injeções mensais são apenas aquelas que o médico achar que há necessidade de tal medicação, não sendo indicado esse tipo de tratamento antes da cirurgia só por causa da pesquisa ou sem indicação precisa do médico atendente.

A Sra. também será submetida a ultra-som transvaginal que é um exame onde o médico introduz uma câmera na vagina e vê através de um monitor se o seu mioma diminuiu ou continua com o mesmo tamanho.

3. Desconfortos e riscos esperados - A retirada de $10 \mathrm{ml}$ de sangue e também dos outros exames de sangue pré-operatórios da veia do braço poderá causar pequeno desconforto, como dor durante a punção da veia e possível arroxeamento do local de punção, que desaparecerá em alguns dias. Em relação à coleta dos pedaços de mioma e músculo uterino normal, referimos que estes procedimentos não trarão dor, pois serão realizados com a Sra. anestesiada, e não trará nenhum risco de complicação ou prejuízo ao resultado final à cirurgia proposta. A cirurgia como qualquer outra pode ter complicações como infecção, sangramento, pode ocorrer ainda a mudança de conduta médica por risco de vida e daí a necessidade de retirada do útero.

A Sra que necessitar tomar o Análogo de GnRH antes da cirurgia, poderá sentir dor no local da injeção na pele da barriga abaixo do umbigo, como em qualquer tipo de injeção, poderá apresentar arroxeamento no local que 
geralmente desaparece sozinho em alguns dias. O efeito dessa medicação causa a suspensão da produção dos hormônios femininos durante o tempo de uso e por isso podem causar sintomas parecidos com aqueles que aparecem na mulher na época da menopausa como: calores, irritação, insônia e parada da menstruação. Esses sintomas desaparecem com a parada da medicação após o término do tratamento.

4. Benefícios que poderão ser obtidos - Para a Sra. que necessitar usar o Análogo de $\mathrm{GnRH}$ o benefício é a redução do mioma uterino antes da cirurgia e a melhora de anemia, se houver, diminuindo também a possibilidade de transfusão sanguínea.

A cirurgia proposta trará melhora de dores e sangramentos menstruais aumentados trazendo assim melhor qualidade de vida e a possibilidade, com a manutenção do útero, de gravidez caso esse seja o seu desejo.

A análise do sangue, pedaço de mioma e músculo uterino normal colhido durante a cirurgia será analisado em laboratório e o resultado poderá nos ajudar a entender melhor o causa do aparecimento do mioma do útero e procurar novas formas de tratamento.

5. Procedimentos alternativos que possam ser vantajosos para o individuo Como hoje a retirada do útero é o único tratamento definitivo para o mioma a Sra. poderá optar por esse tratamento. A retirada do mioma é um tratamento para aquelas pacientes jovens que desejam engravidar ou simplesmente não querem retirar o útero. Outro tratamento é a embolização do mioma que é uma técnica nova onde o médico injeta um medicamento na artéria do útero para entupi-lá e com isso causar a melhora do sangramento, dor e diminuição gradativa do tamanho do útero. Esse procedimento só é feito a critério do médico, pois nem todas as pacientes são candidatas ideais.

IV - ESCLARECIMENTOS DADOS PELO PESQUISADOR SOBRE GARANTIAS DO SUJEITO DA PESQUISA CONSIGNANDO:

1. A paciente que aceitar participar do estudo terá acesso, a qualquer tempo, às informações sobre procedimentos, riscos e benefícios relacionados à pesquisa, inclusive para solucionar eventuais dúvidas.

2. A paciente terá liberdade de retirar seu consentimento a qualquer momento e deixar de participar do estudo, sem que isto traga prejuízo à continuidade do seu tratamento e assistência médica.

3. Salvaguarda da confidencialidade, sigilo e privacidade. 
4. Não existe indenização pelos riscos descritos anteriormente. A Sra. se não desejar participar dessa pesquisa será tratada normalmente no Ambulatório de mioma e para isso não deverá assinar esse documento.

V. INFORMAÇÕES DE NOMES, ENDEREÇOS E TELEFONES DOS RESPONSÁVEIS PELO ACOMPANHAMENTO DA PESQUISA, PARA CONTATO EM CASO DE INTERCORRÊNCIAS CLÍNICAS E REAÇÕES ADVERSAS.

Dr. Rodrigo Borsari e Dr. Nilo Bozzini, nos telefones 3069-6647, 3069-6054.

\section{OBSERVAÇÕES COMPLEMENTARES:}

A medicação em uso para algumas pacientes que participarão do estudo não está em pesquisa. A goserelina (Zoladex®) é uma medicação já aprovada, usada para tratamento de miomas há algum tempo e tem como objetivo, diminuir o tamanho do tumor e interromper a menstruação, facilitando assim a cirurgia e melhorando as condições pré-operatórias da paciente, auxiliando na melhora de anemia, por exemplo. Os efeitos colaterais mais freqüentes são calores, irritabilidade e insônia, sintomas semelhantes com aqueles da menopausa. No entanto, esses efeitos colaterais são bem tolerados e regridem totalmente ao final do uso, retornando também o fluxo menstrual. Portanto, a cirurgia é necessária ao final do tratamento.

\section{VII - CONSENTIMENTO PÓS-ESCLARECIDO}

Declaro que, após convenientemente esclarecido pelo pesquisador e ter entendido o que me foi explicado, consinto em participar do presente Protocolo de Pesquisa

São Paulo, 2006.

assinatura do sujeito da pesquisa

ou responsável legal assinatura do pesquisador

(carimbo ou nome Legível) 


\section{ANEXO 3}

\begin{tabular}{|c|c|c|c|c|c|c|c|c|c|c|c|c|c|c|c|c|c|}
\hline Amostra & RG-HC & $\begin{array}{l}\text { Idade } \\
\text { (anos) }\end{array}$ & Raça & $\begin{array}{c}\text { IMC } \\
(\mathrm{Kg} / \mathrm{m} 2)\end{array}$ & Gesta & Para & Aborto & Análogo & $\begin{array}{c}\text { Maior } \\
\text { Nódulo } \\
(\mathrm{mm})\end{array}$ & $\begin{array}{l}\mathrm{N}^{\circ} \mathrm{de} \\
\text { Nódulos }\end{array}$ & $\begin{array}{c}\text { Volume } \\
\text { uterino } \\
1 \text { (cc) }\end{array}$ & $\begin{array}{c}\text { Volume } \\
\text { uterino } \\
2 \text { (cc) }\end{array}$ & Redução & $\begin{array}{l}\text { Hb Pré } \\
\text { (mg/dl) }\end{array}$ & $\begin{array}{l}\text { Ht Pré } \\
(\%)\end{array}$ & $\begin{array}{l}\text { Hb Pós } \\
\text { (mg/dl) }\end{array}$ & $\begin{array}{l}\text { Ht Pós } \\
(\%)\end{array}$ \\
\hline M49 & 89030805-E & 31 & negra & 29,71 & 0 & 0 & 0 & 1 & 90 & 9 & 591 & 390 & $34 \%$ & 9,9 & 27,9 & 11,9 & 30,2 \\
\hline M35 & $13470602 \mathrm{a}$ & 32 & negra & 21,83 & 0 & 0 & 0 & 1 & 55 & 5 & 211 & 182 & $14 \%$ & 9,8 & 34,8 & 12,3 & 36,8 \\
\hline M12 & $13650642 i$ & 26 & negra & 26,37 & 0 & 0 & 0 & 1 & 130 & 8 & 1461 & 1051 & $28 \%$ & 11,5 & 34,2 & 13,1 & 38,5 \\
\hline M38 & $13723735 \mathrm{~A}$ & 35 & negra & 22,41 & 1 & 0 & 1 & 1 & 125 & 8 & 518 & 395 & $24 \%$ & 14,3 & 43,1 & 14,4 & 43,6 \\
\hline M11 & $13642923 i$ & 39 & negra & 36,45 & 0 & 0 & 0 & 1 & 50 & 8 & 328 & 177 & $46 \%$ & 11,6 & 34,9 & 13,6 & 41,1 \\
\hline M33 & $3106579 j$ & 40 & negra & 25,81 & 0 & 0 & 0 & 1 & 100 & 17 & 225 & 156 & $31 \%$ & 13,8 & 41,1 & 14 & 42,9 \\
\hline M7 & $13660108 \mathrm{~g}$ & 35 & negra & 27,53 & 0 & 0 & 0 & 1 & 120 & 9 & 865 & 563 & $35 \%$ & 11,9 & 36,2 & 13,3 & 39,3 \\
\hline M91 & $13792653 \mathrm{H}$ & 38 & negra & 29,64 & 0 & 0 & 0 & 1 & 10 & 5 & 324 & 190 & $41 \%$ & 9,8 & 32 & 13,3 & 40,4 \\
\hline M19 & $13687755 a$ & 30 & negra & 21,04 & 2 & 0 & 0 & 1 & 60 & 3 & 524 & 342 & $35 \%$ & 12,3 & 12,8 & 38,1 & 41,7 \\
\hline M4 & $13658474 \mathrm{j}$ & 36 & negra & 22,21 & 0 & 0 & 0 & 1 & 60 & 7 & 1145 & 392 & $66 \%$ & 11,3 & 35,4 & 13,2 & 41,5 \\
\hline M78 & 89023758-D & 36 & negra & 21,67 & 0 & 0 & 0 & 1 & 105 & 5 & 737 & 500 & $32 \%$ & 5,4 & 10,6 & 19,8 & 37 \\
\hline M25 & $13680697 d$ & 34 & negra & 22,04 & 0 & 0 & 0 & 1 & 80 & 4 & 539 & 555 & $-3 \%$ & 12 & 38,2 & 13,2 & 39,6 \\
\hline M64 & 13731621-E & 45 & negra & 28,32 & 2 & 2 & 0 & 1 & 100 & 12 & 2546 & 2060 & $19 \%$ & 13,4 & 41,8 & 14,1 & 42,5 \\
\hline M26 & $3026791 j$ & 38 & negra & 33,34 & 1 & 1 & 0 & 1 & 160 & 4 & 3000 & 2100 & $30 \%$ & 12,9 & 41 & 14,1 & 44,8 \\
\hline M2 & $13690072 \mathrm{k}$ & 38 & negra & 26,06 & 0 & 0 & 0 & 1 & 150 & 1 & 2780 & 2142 & $23 \%$ & 12,7 & 39,8 & 12,9 & 39,8 \\
\hline M5 & $13494249 \mathrm{j}$ & 35 & negra & 32,37 & 1 & 1 & 0 & 1 & 145 & 2 & 766,8 & 448 & $42 \%$ & 14,2 & 44,6 & 12,9 & 41,3 \\
\hline M87 & $89038287 \mathrm{G}$ & 40 & negra & 24,09 & 0 & 0 & 0 & 1 & 120 & 6 & 892 & 613 & $31 \%$ & 10,5 & 30,1 & 12,5 & 32,5 \\
\hline M45 & $13696350 \mathrm{~J}$ & 38 & negra & 26,04 & 0 & 0 & 0 & 1 & 110 & 1 & 1007 & 889 & $12 \%$ & 11,7 & 36,2 & 13,9 & 41,9 \\
\hline M59 & $13722289 \mathrm{G}$ & 43 & negra & 23,34 & 0 & 0 & 0 & 1 & 40 & 4 & 1230 & 896 & $27 \%$ & 8,2 & 28,5 & 11,5 & 35 \\
\hline M9 & $13490660 f$ & 36 & negra & 27,33 & 0 & 0 & 0 & 1 & 90 & 8 & 1172 & 929 & $21 \%$ & 11.2 & 38,5 & 13,9 & 40,6 \\
\hline M37 & $13728690 \mathrm{k}$ & 36 & negra & 35,55 & 1 & 1 & 0 & 1 & 55 & 2 & 505 & 451 & $11 \%$ & 14,4 & 43,5 & 14,9 & 43,8 \\
\hline
\end{tabular}


ANEXO 3

\begin{tabular}{|c|c|c|c|c|c|c|c|c|c|c|c|c|c|c|c|c|c|}
\hline Amostra & RG-HC & $\begin{array}{l}\text { Idade } \\
\text { (anos) }\end{array}$ & Raça & $\begin{array}{c}\text { IMC } \\
(\mathrm{Kg} / \mathrm{m} 2)\end{array}$ & Gesta & Para & Aborto & Análogo & $\begin{array}{l}\text { Maior } \\
\text { Nódulo } \\
(\mathrm{mm})\end{array}$ & $\begin{array}{l}\mathrm{N}^{\circ} \text { de } \\
\text { Nódulos }\end{array}$ & $\begin{array}{c}\text { Volume } \\
\text { uterino } \\
1 \text { (cc) }\end{array}$ & $\begin{array}{c}\text { Volume } \\
\text { uterino } \\
2 \text { (cc) }\end{array}$ & Redução & $\begin{array}{l}\text { Hb Pré } \\
\text { (mg/dl) }\end{array}$ & $\begin{array}{l}\text { Ht Pré } \\
(\%)\end{array}$ & $\begin{array}{l}\text { Hb Pós } \\
\text { (mg/dll) }\end{array}$ & $\begin{array}{l}\text { Ht Pós } \\
(\%)\end{array}$ \\
\hline M32 & $13703836 \mathrm{~h}$ & 39 & negra & 32,44 & 1 & 0 & 1 & 1 & 160 & 15 & 1500 & 1236 & $18 \%$ & 12,4 & 39,3 & 14,4 & 41,4 \\
\hline M52 & 89031927-J & 44 & negra & 21,33 & 0 & 0 & 0 & 1 & 70 & 6 & 293 & 165 & $44 \%$ & 9,1 & 29,6 & 13,5 & 45,3 \\
\hline M18 & $3200987 \mathrm{e}$ & 40 & negra & 28,90 & 0 & 0 & 0 & 1 & 70 & 6 & 442 & 223 & $50 \%$ & 8,4 & 29,4 & 9,4 & 32 \\
\hline M51 & $89028727-\mathrm{K}$ & 38 & negra & 21,41 & 0 & 0 & 0 & 1 & 90 & 6 & 730 & 420 & $42 \%$ & 11,3 & 37 & 13 & 42 \\
\hline M27 & $13675808 c$ & 30 & negra & 30,66 & 0 & 0 & 0 & 1 & 82 & 8 & 614 & 173 & $72 \%$ & 11,2 & 33,2 & 12,3 & 36 \\
\hline M86 & $13765041 \mathrm{~K}$ & 36 & negra & 22,89 & 0 & 0 & 0 & 1 & 80 & 8 & 330 & 258 & $21,82 \%$ & 11,5 & 32,3 & 12,9 & 35 \\
\hline M29 & $13697542 i$ & 30 & negra & 25,24 & 0 & 0 & 0 & 1 & 60 & 12 & 949 & 504,9 & $46,80 \%$ & 10,6 & 30,8 & 12,8 & 35,8 \\
\hline M41 & $13734318 \mathrm{I}$ & 36 & negra & 20,83 & 0 & 0 & 0 & 1 & 70 & 20 & 672 & 425 & $36,76 \%$ & 11,2 & 30,9 & 34,1 & 36,6 \\
\hline M90 & $89040559 \mathrm{C}$ & 38 & negra & 24,51 & 0 & 0 & 0 & 1 & 90 & 14 & 450 & 314 & $30,22 \%$ & 12,9 & 37 & 13,5 & 37 \\
\hline M43 & $17739684 \mathrm{~J}$ & 38 & negra & 27,48 & 0 & 0 & 0 & 1 & 65 & 5 & 560 & 376 & $32,86 \%$ & 12 & 38 & 13,6 & 38,5 \\
\hline M34 & $13712339 \mathrm{~b}$ & 31 & negra & 26,78 & 1 & 0 & 1 & 1 & 88 & 10 & 790 & 500 & $36,71 \%$ & 14,5 & 39 & 14,4 & 39,9 \\
\hline M17 & $13712557 a$ & 37 & negra & 23,93 & 1 & 1 & 0 & 1 & 75 & 4 & 347 & 247 & $28,82 \%$ & 12,3 & 35,7 & 13,1 & 37 \\
\hline M22 & $13643384 i$ & 35 & negra & 29,16 & 1 & 0 & 1 & 1 & 31 & 3 & 327 & 255 & $22,02 \%$ & 9,6 & 32,1 & 11,8 & 35 \\
\hline M3 & 3329580h & 38 & negra & 19,31 & 0 & 0 & 0 & 1 & 86 & 8 & 668 & 510 & $23,65 \%$ & 8,5 & 29,4 & 10,5 & 34,2 \\
\hline M42 & 3298570 C & 43 & negra & 32,04 & 2 & 0 & 2 & 1 & 99 & 5 & 440 & 298 & $32,27 \%$ & 9,9 & 29,6 & 10,8 & 36 \\
\hline M30 & $4068633 j$ & 31 & negra & 20,87 & 0 & 0 & 0 & 1 & 110 & 10 & 952,44 & 720 & $24,40 \%$ & 10,1 & 30,5 & 12,3 & 38,8 \\
\hline M1 & $13676471 \mathrm{k}$ & 29 & negra & 36,94 & 0 & 0 & 0 & 1 & 105 & 9 & 1373 & 980 & $28,62 \%$ & 10,8 & 31,6 & 12,9 & 37,9 \\
\hline
\end{tabular}




\begin{tabular}{|c|c|c|c|c|c|c|c|c|c|c|c|c|c|c|}
\hline \multicolumn{15}{|c|}{ ANEXO 4} \\
\hline Amostra & RG-HC & Idade & Raça & $\underset{\mathrm{Kg} / \mathrm{m} 2}{\mathrm{IMC}}$ & Gesta & Para & Aborto & Análogo & $\begin{array}{l}\text { Fase do } \\
\text { ciclo em } \\
\text { dias }\end{array}$ & $\begin{array}{c}\text { Maior } \\
\text { nódulo } \\
(\mathrm{mm})\end{array}$ & $\begin{array}{c}\mathbf{N}^{\circ} \text { de } \\
\text { nódulos }\end{array}$ & $\begin{array}{c}\text { Volume } \\
\text { uterino (cc) }\end{array}$ & $\mathrm{Hb}(\mathrm{dg} / \mathrm{ml})$ & $\mathrm{Ht}(\%)$ \\
\hline M44 & $3104523 \mathrm{H}$ & 32 & negra & 20,44 & 0 & 0 & 0 & 0 & 25 & 130 & 5 & 847 & 8,7 & 25,4 \\
\hline M50 & $89027372-K$ & 45 & negra & 33,25 & 7 & 4 & 3 & 0 & 56 & 155 & 10 & 727,8 & 8,5 & 29 \\
\hline M16 & $13704180 \mathrm{k}$ & 29 & negra & 22,57 & 0 & 0 & 0 & 0 & 28 & 80 & 3 & 413 & 13,2 & 40,3 \\
\hline M23 & $13704376 \mathrm{k}$ & 34 & negra & 27,68 & 0 & 0 & 0 & 0 & 20 & 60 & 8 & 555 & 11,5 & 37 \\
\hline M75 & $2480355-\mathrm{H}$ & 38 & negra & 23,55 & 1 & 1 & 0 & 0 & 16 & 45 & 2 & 174 & 14,3 & 44 \\
\hline M36 & $3021815 G$ & 39 & negra & 22,03 & 2 & 0 & 2 & 0 & 7 & 90 & 5 & 144 & 15,3 & 47,3 \\
\hline M10 & $2013665 d$ & 42 & negra & 23,73 & 1 & 0 & 1 & 0 & 28 & 120 & 8 & 635 & 14,5 & 42,9 \\
\hline M67 & $89024106-G$ & 44 & negra & 25,93 & 3 & 3 & 0 & 0 & 24 & 100 & 6 & 145 & 13,9 & 44 \\
\hline M6 & $13695516 \mathrm{~B}$ & 32 & negra & 21,88 & 4 & 0 & 3 & 0 & 30 & 90 & 5 & 282 & 12,8 & 39,4 \\
\hline M66 & 13730747-E & 34 & negra & 25,10 & 0 & 0 & 0 & 0 & 0 & 70 & 2 & 723 & 12,8 & 37,2 \\
\hline M84 & $89033349 \mathrm{E}$ & 44 & negra & 25,78 & 0 & 0 & 0 & 0 & 17 & 42 & 9 & 431 & 13,5 & 40,7 \\
\hline M79 & 13723321-B & 43 & negra & 23,74 & 0 & 0 & 0 & 0 & 16 & 15 & 5 & 260 & 14,6 & 43 \\
\hline M40 & $13734126 \mathrm{E}$ & 35 & negra & 37,92 & 1 & 0 & 1 & 0 & 14 & 80 & 11 & 1280 & 11,9 & 37,6 \\
\hline M89 & $89034760 \mathrm{I}$ & 44 & negra & 25,26 & 2 & 1 & 1 & 0 & 49 & 100 & 2 & 1193 & 14,2 & 44,1 \\
\hline M54 & 7044659-F & 44 & negra & 24,72 & 1 & 1 & 0 & 0 & 29 & 60 & 2 & 283,1 & 12,8 & 40,1 \\
\hline M55 & 13754758-B & 43 & negra & 30,13 & 3 & 2 & 1 & 0 & 31 & 28 & 1 & 170 & 12,3 & 38,3 \\
\hline M60 & 13603524-J & 44 & negra & 29,62 & 3 & 2 & 1 & 0 & 37 & 30 & 9 & 387 & 12,5 & 38,5 \\
\hline M73 & I-13734791 & 45 & negra & 27,67 & 1 & 1 & 0 & 0 & 11 & 120 & 7 & 640 & 12,4 & 40,6 \\
\hline M68 & $89026447-\mathrm{E}$ & 38 & negra & 23,81 & 3 & 3 & 0 & 0 & 80 & 30 & 8 & 260 & 13 & 41,6 \\
\hline M28 & $13715517 i$ & 33 & negra & 26,35 & 1 & 1 & 0 & 0 & 15 & 75 & 1 & 494 & 13,2 & 40 \\
\hline M13 & $2439290 a$ & 38 & negra & 23,74 & 1 & 0 & 1 & 0 & 17 & 100 & 2 & 523 & 12,2 & 38,1 \\
\hline M24 & $2988720 \mathrm{~h}$ & 37 & negra & 36,49 & 5 & 2 & 3 & 0 & 11 & 35 & 6 & 668 & 13,5 & 41,6 \\
\hline
\end{tabular}




\begin{tabular}{|c|c|c|c|c|c|c|c|c|c|c|c|c|c|c|}
\hline \multicolumn{14}{|c|}{ ANEXO 4} & \multirow{2}{*}{$\begin{array}{c}\text { Continuaçã } \\
\begin{array}{c}\mathbf{H t}(\%)\end{array}\end{array}$} \\
\hline Amostra & RG-HC & Idade & Raça & $\underset{\mathrm{Kg} / \mathrm{m} 2}{\mathrm{IMC}}$ & Gesta & Para & Aborto & Análogo & $\begin{array}{c}\begin{array}{c}\text { Fase do } \\
\text { ciclo em } \\
\text { dias }\end{array} \\
\end{array}$ & $\begin{array}{c}\text { Maior } \\
\text { nódulo } \\
(\mathrm{mm})\end{array}$ & $\begin{array}{c}\mathrm{N}^{\circ} \text { de } \\
\text { nódulos }\end{array}$ & $\begin{array}{c}\text { Volume } \\
\text { uterino (cc) }\end{array}$ & $\mathrm{Hb}(\mathrm{dg} / \mathrm{ml})$ & \\
\hline M39 & $13744836 \mathrm{~A}$ & 42 & negra & 24,67 & 0 & 0 & 0 & 0 & 34 & 100 & 7 & 3150 & 14,4 & 44,4 \\
\hline M72 & $13737291-C$ & 40 & negra & 29,36 & 2 & 2 & 0 & 0 & 8 & 100 & 11 & 1037 & 13,7 & 42 \\
\hline M58 & $5249475-\mathrm{K}$ & 45 & negra & 28,39 & 5 & 4 & 1 & 0 & 23 & 62 & 8 & 372 & 12,1 & 37,5 \\
\hline M63 & 89028060-A & 43 & negra & 28,28 & 0 & 0 & 0 & 0 & 28 & 55 & 10 & 560 & 14,8 & 46 \\
\hline M82 & 89024799-H & 44 & negra & 29,72 & 2 & 2 & 0 & 0 & 30 & 85 & 6 & 624 & 11,1 & 38 \\
\hline M56 & 13747093-C & 42 & negra & 25,28 & 4 & 3 & 1 & 0 & 25 & 40 & 4 & 288 & 14,6 & 44,8 \\
\hline M21 & $13495589 c$ & 38 & negra & 25,44 & 1 & 0 & 1 & 0 & 20 & 125 & 7 & 145 & 12,1 & 38,9 \\
\hline M46 & $13731741 \mathrm{~F}$ & 37 & negra & 24,92 & 0 & 0 & 0 & 0 & 20 & 60 & 7 & 422 & 15,5 & 46,4 \\
\hline M15 & $13661814 \mathrm{~h}$ & 34 & negra & 30,22 & 0 & 0 & 0 & 0 & 20 & 100 & 12 & 397,5 & 14,3 & 42,6 \\
\hline M62 & $13727471-G$ & 45 & negra & 19,79 & 3 & 3 & 0 & 0 & 12 & 100 & 14 & 943 & 10,6 & 36,2 \\
\hline M76 & 89026952-I & 43 & negra & 26,64 & 0 & 0 & 0 & 0 & 34 & 100 & 6 & 1160 & 9,4 & 32,6 \\
\hline M61 & $13750147-\mathrm{F}$ & 44 & negra & 37,96 & 7 & 6 & 1 & 0 & 26 & 80 & 1 & 448 & 13 & 41,1 \\
\hline M81 & 89025155-J & 44 & negra & 40,44 & 3 & 3 & 0 & 0 & 38 & 22 & 10 & 324 & 13,2 & 41,6 \\
\hline M14 & $13651989 f$ & 37 & negra & 24,61 & 0 & 0 & 0 & 0 & 19 & 90 & 15 & 480 & 8,1 & 26 \\
\hline M65 & 89024579-K & 45 & negra & 27,99 & 1 & 1 & 0 & 0 & 15 & 20 & 1 & 94 & 16,1 & 45,6 \\
\hline M53 & 13491702-B & 43 & negra & 33,75 & 1 & 1 & 0 & 0 & 2 & 95 & 9 & 537 & 15,5 & 45 \\
\hline M85 & $89035561 \mathrm{~K}$ & 39 & negra & 22,67 & 0 & 0 & 0 & 0 & 99 & 65 & 5 & 300 & 12,7 & 39 \\
\hline M83 & 13715542-E & 44 & negra & 34,57 & 3 & 3 & 0 & 0 & 18 & 60 & 9 & 564 & 13 & 41,2 \\
\hline M74 & $89026460-\mathrm{F}$ & 42 & negra & 14,40 & 0 & 0 & 0 & 0 & 17 & 135 & 1 & 928,4 & 14,6 & 43 \\
\hline M69 & $89029002-\mathrm{A}$ & 41 & negra & 22,76 & 3 & 0 & 3 & 0 & 17 & 4,5 & 2 & 271 & 13,5 & 40 \\
\hline M48 & $89027402-\mathrm{F}$ & 42 & negra & 24,98 & 3 & 3 & 0 & 0 & 46 & 3,5 & 4 & 276 & 11,8 & 39,1 \\
\hline M77 & 4058479-F & 42 & negra & 38,46 & 0 & 0 & 0 & 0 & 10 & 120 & 20 & 1110 & 13,7 & 40,4 \\
\hline
\end{tabular}




ANEXO 4
\begin{tabular}{|c|c|c|c|c|c|c|c|c|c|c|c|c|c|c|} 
Amostra & RG-HC & Idade & Raça & $\begin{array}{c}\text { IMC } \\
\text { Kg/m2 }\end{array}$ & Gesta & Para & Aborto & Análogo & $\begin{array}{c}\text { Fase do } \\
\text { ciclo em } \\
\text { dias }\end{array}$ & $\begin{array}{c}\text { Maior } \\
\text { nódulo } \\
(\mathbf{m m})\end{array}$ & $\begin{array}{c}\mathbf{N}^{\circ} \text { de } \\
\text { nódulos }\end{array}$ & $\begin{array}{c}\text { Volume } \\
\text { uterino (cc) }\end{array}$ & Hb (dg/ml) & Ht (\%) \\
\hline M71 & $13720155-\mathrm{A}$ & 36 & negra & 18,55 & 0 & 0 & 0 & 0 & 3 & 36 & 4 & 285 & 13,6 & 42,2 \\
\hline M57 & $3087174-G$ & 43 & negra & 35,50 & 5 & 5 & 0 & 0 & 28 & 49 & 8 & 308,5 & 13,8 & 42,3 \\
\hline M88 & $89039620 \mathrm{~K}$ & 33 & negra & 23,59 & 0 & 0 & 0 & 0 & 14 & 45 & 6 & 214 & 12 & 40,5 \\
\hline M70 & $89029366-\mathrm{K}$ & 31 & negra & 25,71 & 0 & 0 & 0 & 0 & 6 & 30 & 9 & 590 & 14,3 & 44,1 \\
\hline M80 & $13746125-\mathrm{A}$ & 40 & negra & 23,05 & 1 & 0 & 1 & 0 & 9 & 63 & 12 & 417 & 9,2 & 32,4 \\
\hline M20 & $4007660 a$ & 44 & negra & 28,07 & 0 & 0 & 0 & 0 & 23 & 29 & 3 & 157 & 14,4 & 44,7 \\
\hline M47 & $89027487-$-J & 43 & negra & 38,28 & 6 & 4 & 2 & 0 & 19 & 40 & 4 & 332 & 11,2 & 36 \\
\hline
\end{tabular}


ANEXO 5: Análise descritiva do quadro clínico das pacientes selecionadas com uso prévio à cirurgia de análogo de GnRH - Grupo A (Tratado).

\begin{tabular}{|c|c|c|c|c|c|c|c|c|c|c|c|c|c|}
\hline Pacientes & $\begin{array}{l}\text { Idade } \\
\text { (anos) }\end{array}$ & $\underset{\left(\mathrm{Kg} / \mathrm{m}^{2}\right)}{\operatorname{IMC}}$ & $\begin{array}{l}\text { Maior } \\
\text { nódulo } \\
\text { (mm) }\end{array}$ & $\begin{array}{c}\mathrm{N}^{\circ} \mathrm{de} \\
\text { nódulos }\end{array}$ & $\begin{array}{l}\text { Volume } \\
\text { Pré (cc) }\end{array}$ & $\begin{array}{l}\text { Volume } \\
\text { Pós (cc) }\end{array}$ & $\begin{array}{c}\text { Variação } \\
\text { volume } \\
(\%)\end{array}$ & $\begin{array}{l}\text { Hb Pré } \\
\text { (md/dl) }\end{array}$ & $\begin{array}{l}\text { Ht Pré } \\
(\%)\end{array}$ & $\begin{array}{l}\text { Hb Pós } \\
\text { (md/dl) }\end{array}$ & $\begin{array}{c}\text { Ht Pós } \\
(\%)\end{array}$ & $\underset{(m \mathrm{~m} / \mathrm{dl})}{\Delta \mathrm{Hb}}$ & $\Delta \mathrm{Ht}(\%)$ \\
\hline M1 & 29 & 36,94 & 105 & 9 & 1373 & 980 & 28,62 & 10,8 & 31,6 & 12,9 & 37,9 & 2,1 & 6,3 \\
\hline M3 & 38 & 19,31 & 86 & 8 & 668 & 510 & 23,65 & 8,5 & 29,4 & 10,5 & 34,2 & 2 & 4,8 \\
\hline M18 & 40 & 28,90 & 70 & 6 & 442 & 223 & 49,55 & 8,4 & 29,4 & 9,4 & 32 & 1 & 2,6 \\
\hline M25 & 34 & 22,04 & 80 & 4 & 539 & 455 & 15,58 & 12 & 38,2 & 13,2 & 39,6 & 1,2 & 1,4 \\
\hline M33 & 40 & 25,81 & 100 & 17 & 325 & 156 & 52,00 & 13,8 & 41,1 & 14 & 42,9 & 0,2 & 1,8 \\
\hline M35 & 32 & 21,83 & 55 & 5 & 311 & 182 & 41,48 & 9,8 & 34,8 & 12,3 & 36,8 & 2,5 & 2 \\
\hline M12 & 26 & 26,37 & 130 & 8 & 1461 & 1051 & 28,06 & 11,5 & 34,2 & 13,1 & 38,5 & 1,6 & 4,3 \\
\hline M4 & 36 & 22,21 & 60 & 7 & 1145 & 392 & 65,76 & 11,3 & 35,4 & 13,2 & 41,5 & 1,9 & 6,1 \\
\hline M9 & 36 & 27,33 & 90 & 8 & 1172 & 929 & 20,73 & 11.2 & 38,5 & 13,9 & 40,6 & 2,7 & 2,1 \\
\hline M29 & 30 & 25,24 & 60 & 12 & 949 & 504,9 & 46,80 & 10,6 & 30,8 & 12,8 & 35,8 & 2,2 & 5 \\
\hline Média & 34,10 & 25,60 & 83,60 & 8,40 & 838,50 & 538,29 & 37,22 & 10,74 & 34,34 & 12,53 & 37,98 & 1,74 & 3,64 \\
\hline $\begin{array}{l}\text { Desvio } \\
\text { Padrão }\end{array}$ & 4,77 & 4,96 & 23,70 & 3,75 & 435,70 & 335,56 & 16,25 & 1,70 & 4,06 & 1,47 & 3,38 & 0,76 & 1,86 \\
\hline
\end{tabular}




\section{REFERÊNCIAS}


Ahn WS, Kim KW, Bae SM, Yoon JH, Lee JM, Namkoong SE, Kim JH, Kim CK, Lee YJ, Kim YW. Targeted cellular process profiling approach for uterine leiomyoma using cDNA microarray, proteomics and gene ontology analysis. Int J Exp Pathol. 2003;84(6):267-79.

Arslan AA, Gold LI, Mittal K, Suen TC, Belitskaya-Levy I, Tang MS, Toniolo $P$. Gene expression studies provide clues to the pathogenesis of uterine leiomyoma: new evidence and a systematic review. Human Reprod. 2005;20(4):852-63.

Bozzini N, Borsari R, Hilário S G. Análogo de GnRH. In: Mencaglia L, Albuquerque de Neto LC. Histeroscopia cirúrgica. São Paulo: Medsi; 2004. p.133-7.

Bozzini N, Realt C, Fonseca AM, Pinotti JA. Tratamento do mioma uterino. Rev. Ginecol Obstet (São Paulo). 1994;5:243-7.

Bozzini N, Rodrigues CJ, Petti DA, Bevilacqua RG, Gonçalves SP, Pinotti JA. Effects of treatment with gonadotropin releasing hormone agonist on the uterine leiomyomata structure. Acta Obstet Gynecol Scand. 2003;82:330-4.

Carr BR, Marshburn PB, Weatherall PT, Bradshaw KD, Breslau NA, Byrd W, Roark M, Steinkampf MP. An evaluation of the effect of gonadotropinreleasing hormone analogs and medroxyprogesterone acetate on uterine leiomyomata volume by magnetic resonance imaging: a prospective, randomized, double blind, placebo-controlled, crossover trial. J Clin Endocrinol Metab. 1993;76(5):1217-23.

Catherino W, Salama A, Potlog-Nahari C, Leppert P, Tsibris J, Segars J. Gene expression studies in leiomyomata: new directions for research. Semin Reprod Med. 2003;22(2):83-90

Catherino W, Leppert PC, Stenmark MH, Payson M, Potlog-Nahari C, Nieman LK, Segars JH. Reduced dermatopontin expression in a molecular link between uterine leiomyomas and keloids. Genes Chromosomes Cancer. 
2004a;40(3):204-17.

Catherino WH, Prupas C, Tsibris JC, Leppert PC, Payson M, Nieman LK, Segars $\mathrm{JH}$. Strategy for elucidating differentially expressed genes in leiomyomata identified by microarray technology. Fertil Steril. 2003a;80(2):282-90.

Chegini N, Verala J, Luo X, Xu J, Williams RS. Gene expression profile of leiomyoma and myometrium and the effect of gonadotropin releasing hormone analogue therapy. J Soc Gynecol Investig. 2003;10(3):161-71.

Chen CC, Chen N, Lau LF. The angiogenic factors Cyr61 and connective tissue growth factor induce adhesive signaling in primary human skin fibroblasts. J Biol Chem. 2001;276(13):10443-52.

Chen W, Yoshida S, Ohara N, Matsuo H, Morizane M, Maruo T. Gonadotropin-releasing hormone antagonist cetrorelix down-regulates proliferating cell nuclear antigen and epidermal growth factor expression and up-regulates apoptosis in association with enhanced poly(adenosine 5'diphosphate-ribose) polymerase expression in cultured human leiomyoma cells. J Clin Endocrinol Metab. 2005;90(2):884-92.

Cirkel U, Ochs H, Roehl A, Schneider PG. Estrogen and progesterone receptor content of enucleated uterine myomata after luteinizing hormonereleasing hormone. Acta Obstet Gynecol Scand. 1994;73:328-32.

Dal Cin P, Quade BJ, Neskey DM, Kleinman MS, Weremowicz S, Morton CC. Intravenous leiomyomatosis is characterized by a $\operatorname{der}(14) t(12 ; 14)(q 15 ; q 24)$. Genes Chromosomes Cancer. 2003;36(2):205-6.

Day Baird D, Dunson DB, Hill MC, Cousins D, Schectman JM. High cumulative incidence of uterine leiomyoma in black and white women: ultrasound evidence. Am J Obstet Gynecol. 2003;188(1):100-7.

Flake GP, Andersen J, Dixon D. Etiology and pathogenesis of uterine leiomyomas: a review. Environ Health Perspect. 2003;111(8):1037-54. 
Gomes MT, Castro Rde A, Villanova FE, da Silva ID, Baracat EC, de Lima GR, Girão MJ. The progesterone receptor gene polymorphism, PROGINS, may be a factor related to the development of uterine fibroids. Fertil Steril. 2007;87(5):1116-21.

Gross KL, Morton CC. Genetics and the development of fibrinoids. Clin Obstet Gynicol. 2001;44(2):335-49.

Hoffman PJ, Milliken DB, Gregg LC, Davis RR, Gregg JP.Molecular characterization of uterine fibroids and its implication for underlying mechanisms of pathogenesis. Fertil Steril. 2004;82(3):639-49.

Ito $\mathrm{F}$, Kawamura $\mathrm{N}$, Ichimura $\mathrm{T}$, Tsujimura $\mathrm{A}$, Ishiko $\mathrm{O}$, Ogita $\mathrm{S}$. Infrastructural comparison of uterine leiomyoma cells from the same myoma nodule before and after GnRH agonist treatment. Fertil Steril. 2001;75:12530.

Kalir T, Goldstein M, Dottino P, Brodman M, Gordon R, Deligdisch L, Wu H, Gil J. Morphometric and electron-microscopic analyses of the effects of GnRH agonists on uterine leiomyomas. Arch Pathol Lab Med. 1998;122:4426.

Kataoka S, Yamada H, Hoshi N, Kudo M, Hareyama H, Sakuragi N, Fujimoto S. Cytogenetic analysis of uterine leiomyoma: the size, histopathology and GnRHa-response in relation to chromosome karyotype. Eur J Obstet Gynecol Reprod Biol. 2003;110(1):58-62.

Lee EJ, Kong G, Lee SH, Rho SB, Park CS, Kim BG, Bae DS, Kavanagh JJ, Lee $\mathrm{JH}$. Profiling of differentially expressed genes in human uterine leiomyomas. Int J Gynecol Cancer. 2005;15(1):146-54.

Lethaby A, Vollenhoven B, Sowter M. Pre-operative GnRH analogue therapy before hysterectomy or myomectomy for uterine fibroids. Cochrane Database Syst Rev. 2001;(2):CD000547.

Ligon $\mathrm{AH}$, Morton $\mathrm{CC}$. Genetics of uterine leiomyomata. Genes 
Chromosomes Cancer. 2000;28(3):235-45.

Luo X, Ding L, Xu J, Williams RS, Chegini N.Leiomyoma and myometrial gene expression profiles and their responses to gonadotropin-releasing hormone analog therapy. Endocrinology. 2005;146(3):1074-96.

Mangioni S, Viganò $\mathrm{P}$, Lattuada $\mathrm{D}$, Abbiati $\mathrm{A}$, Vignali $\mathrm{M}$, Di Blasio AM. Overexpression of the Wnt5b gene in leiomyoma cells: implications for a role of the Wnt signaling pathway in the uterine benign tumor. J Clin Endocrinol Metab. 2005;90(9):5349-55.

Moraes EA, Ribeiro VL. Genética do leiomioma uterino. In: Bozzini N. Leiomioma uterino. São Paulo: Ed PlanMark; 2005. p.16-25.

Morimoto-Tomita M, Uchimura K, Werb Z, Hemmerich S, Rosen SD. Cloning and characterization of two extracellular heparin-degrading endosulfatases in mice and humans. J Biol Chem. 2002; 277(51):49175-85.

Nagayma T, Simon RP, Chen D, Henshall DC, Pei W, Stetler RA, Chen J. Activation of PARP in the rat hippocampus may contribute to cellular recovery following sublethal transient global ischemia. J Neurochem. 2000;74:1636-45.

Nilbert $M$, Heim S, Mandahl $N$, Flodérus UM, Willén $H$, Mitelman $F$. Characteristic chromosome abnormalities, including rearrangements of $6 p$, del(7q), +12, and $t(12 ; 14)$, in 44 uterine leiomyomas. Hum Genet. 1990;85(6):605-11.

Pan Q, Luo X, Chegini N. Genomic and proteomic profiling I: leiomyomas in African Americans and Caucasians. Reprod Biol Endocrinol. 2007;23(5):34.

Parker WH. Etiology, symptomatology, and diagnosis of uterine myomas. Fertil Steril. 2007;87(4):725-36.

Porter KB, Tsibris JCM, Nicosia SV, Murphy JM, O'Brien WF, Rao PS, Spellacy WN. Estrogen-induce guinea pig model for uterine leiomyoma: do 
the ovaries protect? Biol Reprod. 1995;52 (4):824-32.

Quade BJ, Wang TY, Sornberger K, Dal Cin P, Mutter GL, Morton CC. Molecular pathogenesis of uterine smooth muscle tumors from transcriptional profiling. Genes Chromosomes Cancer. 2004;40(2):97-108.

Reed WB, Walker R, Horowitz R. Cutaneous leiomyomata with uterine leiomyomata. Acta Derm Venereol. 1973;53(5):409-16.

Rein MS, Barbieri RL, Welch W, Gleason RE, Caulfield JP, Friedman AJ. The concentrations of collagen-associated amino acids are higher in $\mathrm{GnRH}$ agonist-treated uterine myomas. Obstet Gynecol. 1993;82:901-5.

Rein MS. Advances in uterine leiomyoma research: the progesterone hypothesis. Environ Health Perspect. 2000;108(Suppl 5):791-3.

Schwartz SM, Marshall LM, Baird DD. Epidemiologic contributions to understanding the etiology of uterine leiomyomata. Environ Health Perspect. 2000;1008(Suppl 5):821-7.

Schwartz SM. Epidemiology of uterine leiomyomata. Clin Obstet Gynecol. 2001;44(2):316-26.

Sell SM, Tullis C, Stracner D, Song CY, Gewin J. Minimal interval defined on $7 q$ in uterine leiomyoma. Cancer Genet Cytogenet. 2005;157(1):67-9.

Shozu M, Murakami K, Segawa T, Kasai T, Ishikawa H, Shinohara K, Okada $\mathrm{M}$, Inoue $\mathrm{M}$. Decreased expression of early growth response-1 and its role in uterine leiomyoma growth. Cancer Res. 2004;64(13):4677-84.

Skubitz KM, Skubitz AP. Differential gene expression in uterine leiomyoma. J Lab Clin Med. 2003;141(5):297-308.

Sozen I, Araci A. Interactions of cytokines, growth factors, and the extracellular matrix in the cellular biology of uterine leiomyomata. Fertil Steril. 2002;78(1):1-12. 
Spong CY, Sinow R, Renslo R, Cabus E, Rutgers J, Kletzky OA. Induced hypoestrogenism increases the arterial resistance index of leiomyomata without affecting uterine or carotid arteries. J Assist Reprod Genet. 1995;12:338-41.

Stewart EA, Nowak RA. New concepts in the treatment of uterine leiomyomas. Obstet Gynecol. 1998;92(4 Pt 1):624-7.

Takahashi K, Kawamura N, Tsujimura A, Ichimura T, Ito F, Ishiko O, Ogita S. Association of the shrinkage of uterine leiomyoma treated with $\mathrm{GnRH}$ agonist and delestion of long arm of chromosome 7. Int J Oncol. 2001;18(6):1259-63.

Tomlinson IP, Alam NA, Rowan AJ, Barclay E, Jaeger EE, Kelsell D, Leigh I, Gorman P, Lamlum H, Rahman S, Roylance RR, Olpin S, Bevan S, Barker K, Hearle N, Houlston RS, Kiuru M, Lehtonen R, Karhu A, Vilkki S, Laiho P, Eklund C, Vierimaa O, Aittomaki K, Hietala M, Sistonen P, Paetau A, Salovaara R, Herva R, Launonen V, Aaltonen LA; Multiple Leiomyoma Consortium. Germline mutations in $\mathrm{FH}$ predispose to dominantly inherited uterine fibroids, skin leiomyomata and papillary renal cell cancer. Nat Genet. 2002;30(4):406-10.

Tsibris JC, Segars J, Coppola D, Mane S, Wilbanks GD, O'Brien WF, Spellacy WN. Insights from gene arrays on the development and growth regulation of uterine leiomyomata. Fertil Steril. 2002;78(1):114-21.

Walker CL, Hunter D, Everitt Jl. Uterine leiomyoma in Eker rat: a unique model for important disease of women. Genes Chromosomes Cancer. 2003;38(4):349-56.

Wang Y, Matsuo H, Kurachi O, Maruo T. Dow-regulation of proliferation andu p-regulation of apoptosis by gonadotrophin-releasing hormone agonist in culture uterine leiomyoma cells. Eur J Endocrinol. 2002;146:447-56.

Wang H, Mahadevappa M, Yamamoto K, Wen Y, Chen B, Warrington JA, Polan ML. Distinctive proliferative phase differences in gene expression in 
human myometrium and leiomyomata. Fertil Steril. 2003;80(2):266-76.

Wei JJ, Chiriboga L, Mittal K. Expression profile of the tumorigenic factors associated with tumor size and sex steroid hormone status in uterine leiomyomata. Fertil Steril. 2005;84(2):474-84.

Wei JJ, Chiriboga L, Arslan AA, Melamed J, Yee H, Mittal K. Ethnic differences in expression of the dysregulated proteins in uterine leiomyomata. Hum Reprod. 2006;21(1):57-67.

Weston G, Trajstman AC, Gargett CE, Manuelpillai U, Vollenhoven BJ, Rogers PA.Fibroids display an anti-angiogenic gene expression profile when compared with adjacent myometrium. Mol Hum Reprod. 2003;9(9):541-9.

Wilson EA, Yang F, Rees D. Estradiol and progesterone binding in uterine leiomyomata and in normal uterine tissues. Obstet Gynecol. 1980;55:20-4.

Wu JM, Wechter ME, Geller EJ, Nguyen TV, Visco AG. Hysterectomy rates in the United States, 2003.Obstet Gynecol. 2007;110(5):1091-5. 